\title{
Four new genera of funnel-web spiders (Araneae: Agelenidae) from the Baja California Peninsula in Mexico
}

\author{
Julieta Maya-Morales ${ }^{1,3}$, María Luisa Jiménez ${ }^{1}$, Gopal Murugan ${ }^{2}$ and Carlos Palacios-Cardiel ${ }^{1}$ : ${ }^{1}$ Laboratorio de \\ Aracnología y Entomología, Centro de Investigaciones Biológicas del Noroeste (CIBNOR), La Paz, Baja California Sur \\ 23096, Mexico; ${ }^{2}$ Centro de Investigaciones Biológicas del Noroeste (CIBNOR), La Paz, Baja California Sur 23096, \\ Mexico. ${ }^{3}$ Corresponding author. E-mail: dianobi@yahoo.com
}

\begin{abstract}
Four new genera of funnel-web spiders of the family Agelenidae C.L. Koch, 1837 from the Baja California Peninsula, Mexico are described and illustrated. Bajacalilena gen. nov. is represented by $B$. bolzerni sp. nov. and $B$. clarki sp. nov. Cabolena gen. nov. is represented by $C$. huiztocatl sp. nov., $C$. kosatli sp. nov., and $C$. sotol sp. nov. Callidalena gen. nov. is represented by $C$. quintin sp. nov. and $C$. tijuana sp. nov. Lagunella gen. nov. is represented by $L$. guaycura sp. nov. Additionally, the males of Calilena angelena Chamberlin \& Ivie, 1941, Hololena septata Chamberlin \& Ivie, 1942, and Rothilena sudcaliforniensis Maya-Morales \& Jiménez, 2013 are described for the first time. New records for $C$. angelena, $H$. septata, R. cochimi Maya-Morales \& Jiménez, 2013, R. pilar Maya-Morales \& Jiménez, 2013, and R. sudcaliforniensis are also provided. Molecular analysis of a fragment of cytochrome c oxidase subunit I (COI) provides support for the monophyly of the new genera and facilitated sorting of conspecific males and females. Finally, an identification key to native Nearctic and Neotropical genera of the subfamily Ageleninae is provided.
\end{abstract}

Keywords: Ageleninae, taxonomy, morphology, barcoding

http://zoobank.org/?lsid=urn:lsid:zoobank.org:pub:AE1C4819-5642-456D-B664-59B3BB33AC55

Agelenidae C.L. Koch, 1837 is one of the most diverse spider families in the world, with 73 genera and 1,201 described species (Bolzern \& Hänggi 2016; World Spider Catalog 2016) in two subfamilies: Ageleninae Simon, 1898 and Coelotinae F.O. Pickard-Cambridge, 1893. However, knowledge of true species diversity is often limited, especially in regions where no major biodiversity inventories have been completed (Bolzern \& Jäger 2015). In Mexico, recent taxonomic works have resulted in an increase in the number of both genera and species (Maya-Morales \& Jiménez 2013, 2016; Bolzern \& Hänggi 2016). The Baja California Peninsula (BCP), the second longest peninsula in the world, is a geographically isolated landmass that stretches over 1,000 $\mathrm{km}$ (Crews \& Hedin 2006). It is a region with a high degree of endemism (Williams 1980; Sissom \& Hendrixon 2005; Rebman \& Roberts 2012), where the diversity of the family Agelenidae is still underestimated (Roth \& Brame 1972).

Banks (1898) described the first species of Agelenidae on the BCP with the female of Agelena peninsulana Banks, 1898, and also reported Tegenaria domestica (Clerck, 1757). Chamberlin (1924) recorded Agelenopsis naevia (Walckenaer, 1841), while Chamberlin \& Ivie (1941) transferred A. peninsulana to Calilena Chamberlin \& Ivie, 1941. Later, Roth \& Brown (1986) reported Agelenopsis potteri (Blackwall, 1846). Recently, Maya-Morales \& Jiménez $(2013,2016)$ described Rothilena with six new species from the southern part of the BCP and three new species of Rualena Chamberlin \& Ivie, 1941 from the northern part of the BCP.

In North America, molecular studies of the subfamily Ageleninae have been carried out mainly with species of Agelenopsis Giebel, 1869 (Ayoub \& Riechert 2004; Ayoub et al. 2005), and only a dozen species from other genera (e.g. Barronopsis Chamberiin \& Ivie, 1941, Calilena, Hololena Chamberlin \& Gertsch, 1929, Novalena Chamberlin \& Ivie,
1942, Rualena and Tegenaria Latreille, 1804) have been sequenced and are available in GenBank. The barcode gene COI (mitochondrial cytochrome c oxidase subunit I) is useful for species-level taxonomy (Robinson et al. 2009; Blagoev et al. 2016) and for establishing the generic affiliation of agelenid species (Bolzern et al. 2010; Bolzern \& Jäger 2015).

The aim of this study was to describe new genera and species of Agelenidae collected from the BCP, using both morphological and molecular characters. We document four new genera and eight new species, and further provide an identification key to native Nearctic and Neotropical genera of the subfamily Ageleninae.

\section{METHODS}

Material examined.-Specimens were examined using a stereomicroscope (Carl Zeiss Stemi SR), and measurements were made with a micrometer slide adapted to one lens, and recorded in millimeters. The epigyna of females were dissected in ethanol (70\%) and later cleaned with a solution of pancreatin, which digests the soft tissues and leaves the rigid parts intact (Álvarez-Padilla \& Hormiga 2007). Drawings of the genitalia were made using a camera lucida adapted to a stereomicroscope (Leica MZ6). Photographs of genitalia were taken at the California Academy of Sciences and Centro de Investigaciones Biológicas del Noroeste with a digital camera adapted to a Leica stereomicroscope. Helicon Focus 6.5.2 software was used for combining digital images. For scanning electron micrographs (SEM; Hitachi S-3000N), specimens were dehydrated in an ethanol series $(70 \%, 80 \%, 90 \%$ and $100 \%$ ), critical-point dried, and mounted on stubs using copper tape and coated with gold using a sputter coater for 70 s. In vivo photographs were taken with a digital camera Sony 
Table 1.-GenBank accession numbers of included COI sequences of Agelenidae.

\begin{tabular}{lc}
\hline \multicolumn{1}{c}{ Species } & $\begin{array}{c}\text { Accession } \\
\text { Number }\end{array}$ \\
\hline Agelenopsis aperta (Gertsch, 1934) & AY676089 \\
Calilena restricta Chamberlin \& Ivie, 1941 & DQ628545 \\
Hololena adnexa (Chamberlin \& Gertsch, 1929) & DQ628541 \\
Eratigena agrestis (Walckenaer, 1802) & GU682805 \\
Novalena intermedia (Chamberlin \& Gertsch, 1930) & DQ628618 \\
\hline
\end{tabular}

Alpha NEX-5N. Distribution maps were created using QGIS 2.8.2 software.

Morphological terminology is based on the criteria of Chamberlin \& Ivie (1942), Roth \& Brame (1972), Maya-Morales \& Jiménez (2013, 2016), and Ramírez (2014). Abbreviations used in the text and figures are as follows: AME, anterior median eyes; ALE, anterior lateral eyes; PME, posterior median eyes; PLE, posterior lateral eyes; $\mathrm{C}$, conductor; $\mathrm{Cd}$, dorsal projection of conductor; $\mathrm{Cdi}$, distal projection of conductor; $\mathrm{Ce}$, ectal projection of conductor; $\mathrm{Cm}$, mesal projection of conductor; $\mathrm{Cv}$, ventral projection of conductor; E, embolus; $\mathrm{F}$, fulcrum; MA, median apophysis; RTA, retrolateral tibial apophysis; RTAb, basal projection of RTA; RTAd, distal projection of RTA; RTAo, dorsal projection of RTA; St, subtegulum; T, tegulum; TMP, tegular median process; A, atrium; BG, Bennett's glands; $C D$, copulatory ducts; $C O$, copulatory openings; FD, fertilization ducts; S, spurs; Sc, Scape; S1, primary spermathecae; S2, secondary spermathecae. For purposes of nomenclature, the new taxa are authored by MayaMorales and Jiménez only, with the exception of Cabolena kosatli, C. sotol and Lagunella guaycura, which are authored by Maya-Morales, Jiménez and Palacios-Cardiel.

The specimens studied belong to the following museums and institutions (abbreviations and curators in parentheses): American Museum of Natural History, New York, USA (AMNH, Norman I. Platnick); California Academy of Sciences, San Francisco, USA (CAS, Charles E. Griswold); Colección de Arácnidos del Centro de Investigaciones Biológicas del Noroeste, La Paz, Mexico (CARCIB, María Luisa Jiménez); Orma J. Smith Museum of Natural History at The College of Idaho, Caldwell, ID, USA and Museo de Artrópodos del Centro de Investigación Científica y de Educación Superior de Ensenada, Ensenada, Baja California, Mexico (OJSMNH and CICESE, William H. Clark); and San Diego Natural History Museum, San Diego, USA (SDNHM, Michael A. Wall). Specimens from the CAS are labeled as
CASENT, and those from OJSMNH and CICESE are labeled as CIDA and ALBRCIDA, respectively. Additionally, we collected new material from several localities in the State of Baja California Sur (2011-2015), deposited at CARCIB.

Molecular data.- To corroborate the morphologically identified species and verify the accuracy of sex pairing in each species, we sequenced the barcoding fragment of mitochondrial COI. Genomic DNA was extracted using spin-columns and following the protocol of Ivanova et al. (2006). Polymerase chain reaction (PCR) amplification of COI was undertaken using the primers LCO1490: 5'-GGTCAACAAATCATAAAGATATTGG-3' and HCO2198: 5'-TAAACTTCAGGGTGACCAAAAAATCA-3' (Folmer et al. 1994). All PCR mixtures contained $3 \mu \mathrm{l}$ DNA, $0.9 \mu \mathrm{l}$ of each primer (20 $\mathrm{mM}), 0.7 \mu \mathrm{l} \mathrm{MgCl}_{2}(50 \mathrm{mM}), 1.7 \mu \mathrm{l}$ PCR buffer $(10 \times), 1 \mu \mathrm{l}$ dNTP $(2.5 \mathrm{mM}), 0.7 \mu$ l betaine $(1 \mathrm{M})$, and $0.1 \mu \mathrm{l}$ DNA Taq polymerase $(5 \mathrm{U} / \mu \mathrm{l})$ in a final volume of $15 \mu \mathrm{l}$. The PCR cycle was: $3 \mathrm{~min}$ at $94^{\circ} \mathrm{C}$; five cycles of $30 \mathrm{~s}$ at $94^{\circ} \mathrm{C}, 40 \mathrm{~s}$ at $45^{\circ} \mathrm{C}$, and $1 \mathrm{~min}$ at $72^{\circ} \mathrm{C} ; 35$ cycles of $30 \mathrm{~s}$ at $94^{\circ} \mathrm{C}, 40 \mathrm{~s}$ at $51^{\circ} \mathrm{C}$, and $1 \mathrm{~min}$ at $72^{\circ} \mathrm{C}$; and a final $5 \mathrm{~min}$ at $72^{\circ} \mathrm{C}$. Amplified products were checked using $2.0 \%$ agarose gel electrophoresis and subsequently sequenced at the University of California Berkeley. The sequences obtained were edited in DNA Baser 4.5 (http:// www.DNABaser.com). The sequence data, together with other COI sequences of Agelenidae from GenBank (http://www. ncbi.nlm.nih.gov/genbank) (Table 1), were analyzed using MEGA 6 (Tamura et al. 2013). Haplotypes were determined in DnaSP 5.10 (Librado \& Rozas 2009) and genetic (uncorrected) distances among the species were calculated in MEGA. We used jModelTest 2.1.9 (Darriba et al. 2012) to select a bestfit nucleotide substitution model (TIM $3+\mathrm{I}+\mathrm{G}$ ), according to the Akaike information criterion (AIC) and implemented in MrBayes 3.2 (Ronquist et al. 2012) for phylogenetic analysis. Two independent MCMC analyses were run for 10 million generations. Trees were sampled every 100 generations, and a $50 \%$ majority rule consensus Bayesian tree was generated with a $25 \%$ burnin. Species designations were further tested using the Automatic Barcode Gap Discovery (ABGD) software for primary species delimitation (Puillandre et al. 2012). All sequences generated in this study are deposited in GenBank (Accession numbers KU976337-KU976384).

\section{TAXONOMY}

Family Agelenidae C.L. Koch, 1837

Subfamily Ageleninae C.L. Koch, 1837

\section{KEY TO THE NATIVE NEARCTIC AND \\ NEOTROPICAL GENERA OF AGELENINAE}

NB. Neotegenaria Roth, 1967, represented only by $N$. agelenoides Roth, 1967, was not examined.

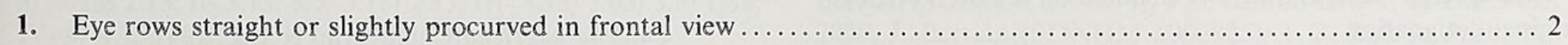

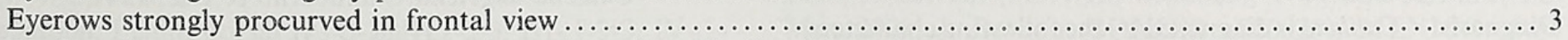

2. Cheliceral retromargin with three to six teeth; male pedipalp without lateroventral ridge on RTA.

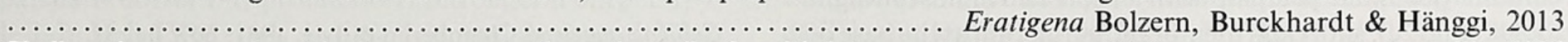
Cheliceralretromargin with six or more teeth; male pedipalp with lateroventral ridge on RTA ..... Tegenaria Latreille, 1804

3. Male pedipalp with tegular lateral process (= tegular apophysis of Stocks 2009: fig. 20); RTA with one projection (Stocks 2009: fig. 38); epigynum with copulatory ducts long or membranous and plicate (Stocks 2009: fig. 52) 
Malepedipalp without tegular lateral process; RTA with two or three projections (Fig. 4e); epigynum with copulatory

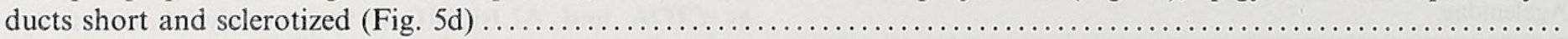

4. Male pedipalp with tethering membrane and radix (Gering 1953: fig. 4); copulatory ducts membranous and plicate

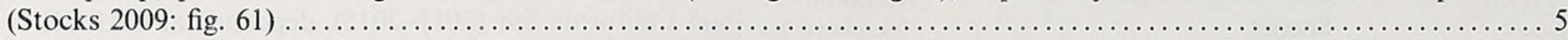

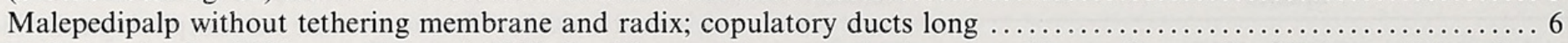

5. Embolus circular (Whitman-Zai et al. 2015: fig. 15); posterior part of epigynum with coupling cavity (Whitman-Zai et al. 2015: fig. 30); distal segment of PLS two times the length of basal segment................ Agelenopsis Giebel, 1869 Embolustightly coiled basally and loosely coiled distally (Stocks 2009: fig. 39); posterior part of epigynum without coupling cavity; distal segment of PLS as long as basal segment............... Barronopsis Chamberlin \& Ivie, 1941

6. Embolus forming an eight (Chamberlin \& Ivie 1941: fig. 76); embolic process a short hook concealed by embolus;

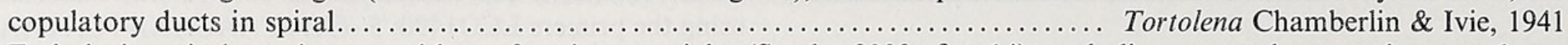
Embolusin spiral or sinuous without forming an eight (Stocks 2009: fig. 14); embolic process large and exposed; copulatory ducts not forming a spiral............................. Melpomene O. Pickard-Cambridge, 1898

7. Male pedipalp with tegular median process (Maya-Morales \& Jiménez 2016: fig. 124); primary spermathecae longer than

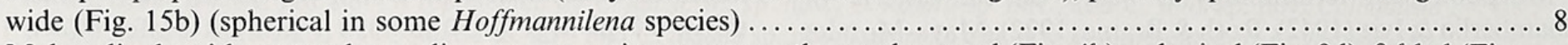
Malepedipalp without tegular median process; primary spermathecae elongated (Fig. 4b), spherical (Fig. 9d), folded (Fig. 19b) or wrinkled (Maya-Morales \& Jiménez 2016: fig. 61).

8. RTA in distal position on tibia (Fig. 22b); embolus originating from basal part of tegulum (Fig. 21a); copulatory ducts surrounding primary spermathecae dorsally (Fig. 21b); secondary spermathecae in anterior part of primary spermathecae

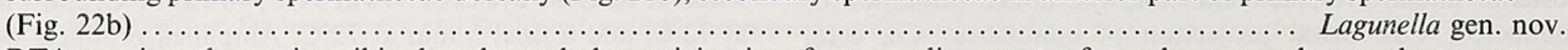
RTAcovering the entire tibia length; embolus originating from median part of tegulum; copulatory ducts not surrounding primary spermathecae dorsally; secondary spermathecae in ectal part of primary spermathecae............ 9

9. RTA usually with three projections (Chamberlin \& Ivie 1942: fig. 59); epigynum with median plate not differentiated from lateral lobes (Maya-Morales \& Jiménez 2016: fig. 89) . . . . . . . . . . . . . . . . . . Novalena Chamberlin \& Ivie, 1942 RTAwith two projections (Fig. 16b); epigynum with median plate differentiated from lateral lobes (Fig. 14c) ........ 10

10. RTA with basal projection (Maya-Morales \& Jiménez 2016: fig. 120); all structures of epigynal plate strongly sclerotized (Maya-Morales \& Jiménez 2016: fig. 130) .................... Hoffmannilena Maya-Morales \& Jiménez, 2016 RTAwith dorsal projection (Fig. 16b); some structures of epigynal plate more sclerotized than others (Fig. 12c) .....

Cabolena gen. nov.

11. Embolus supported by fulcrum and conductor (Fig. 4a); epigynal atrium partially divided by a septum (Fig. 5c)..... Hololena Chamberlin \& Gertsch, 1929

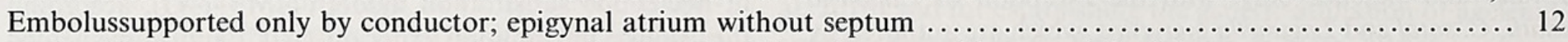

12. RTA with dorsal projection flattened longitudinally (Fig. 3b); epigynum with scape (Fig. 3c) ..................

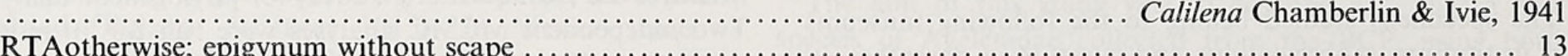

13. RTA in distal position on tibia (Fig. $17 \mathrm{~d}$ ); atrium occupying the entire plate length (Fig. 18c); primary spermathecae folded or wrinkled (Fig. 19b)

RTAcovering the entire tibia length (Fig. 9a); atrium in anterior part of plate (Fig. 10a); primary spermathecae spherical (Fig. 6d)

14. Male pedipalp with membranous fulcrum (Maya-Morales \& Jiménez 2016: fig. 43); conductor with two short projections (Maya-Morales \& Jiménez 2016: fig. 12); epigynal atrium in cavity ............... Rualena Chamberlin \& Ivie, 1942 Malepedipalp without membranous fulcrum; conductor folded longitudinally (Fig. 19c); epigynal atrium flat (Fig. 20c) ...

Callidalena gen. nov.

15. Embolus in spiral with 1.5 coils (Fig. 9c); conductor membranous and horseshoe-shaped (Fig. 9a); copulatory ducts

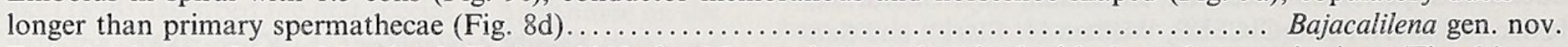
Embolussinuous (Maya-Morales \& Jiménez 2013: fig. 16); conductor sclerotized with three short projections (Fig. 6c); copulatory ducts shorter than primary spermathecae (Fig. 6b)............ Rothilena Maya-Morales \& Jiménez, 2013

Genus Calilena Chamberlin \& Ivie, 1941

Calilena Chamberlin \& Ivie, 1941: 603.

Type species.-Calilena saylori Chamberlin \& Ivie, 1941, by original designation.

Diagnosis.-Calilena is diagnosed by the following characters in combination: male pedipalp with a short and almost straight embolus (Fig. 2c); short and membranous fulcrum at the base of embolus (Fig. 3a); conductor with two projections (Fig. 2a); and RTA covering the entire tibia length (Fig. 3b). Female epigynum with a scape originating from anterior part of atrium and projecting posteriorly (Fig. 3c); primary spermathecae elongated and L-shaped; secondary spermathecae in diverticula and connected to copulatory ducts; and fertilization ducts short (Fig. 2b, d).

Calilena angelena Chamberlin \& Ivie, 1941

(Figs. 2, 3)

Calilena angelena Chamberlin \& Ivie, 1941: 607, fig. 51.

Type material.-Holotype female: Los Angeles, California, USA (AMNH; not examined). 


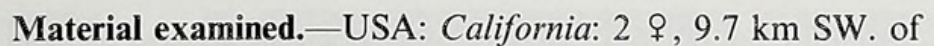
Victorville, $34^{\circ} \mathrm{N}, 117^{\circ} \mathrm{W}, 9$ March 1941 , W. Ivie (AMNH). MEXICO: Baja California: 1 \&, Municipality of Tecate, Highway La Rumorosa-Ojos Negros km $35,32^{\circ} 16^{\prime} 33^{\prime \prime} \mathrm{N}$, $116^{\circ} 12^{\prime} 15^{\prime \prime} \mathrm{W}, 1232 \mathrm{~m}, 3$ March 2010, C. Mayorga \& L. Cervantes (CARCIB 1925); 1 ऽ, Municipality of Ensenada, 8 $\mathrm{km}$ NW of Santo Tomás, $31^{\circ} 37^{\prime} \mathrm{N}, 116^{\circ} 27^{\prime} \mathrm{W}, 200 \mathrm{~m}$, pitfall trap, 11 August - 4 September 1982, W.H. Clark (CIDA 91,767); 8 o, 1 ㅇ, same data except 10 August - 4 September 1982 (CIDA 91,793); 1 §, 2 ㅇ, same data except 4 September 1982 - 7 January 1984 (CIDA 91,843).

Diagnosis.-Females of $C$. angelena differ from C. absoluta (Gertsch, 1936), C. adna Chamberlin \& Ivie, 1941, C. magna Chamberlin \& Ivie, 1941 and C. siva Chamberlin \& Ivie, 1941 by having the scape reaching the posterior margin of the atrium; from $C$. gertschi Chamberlin \& Ivie, 1941 and $C$. saylori by having the scape distally rounded; from $C$. arizonica Chamberlin \& Ivie, 1941 and C. yosemita Chamberlin \& Ivie, 1941 by the having the median plate wider than long; from $C$. californica (Banks, 1896), C. gosoga Chamberlin \& Ivie, 1941 and $C$. restricta Chamberlin \& Ivie, 1941 by having the anterior margin of the median plate slightly pointed; from $C$. stylophora Chamberlin \& Ivie, 1941 by having the scape thicker and shorter; and from C. umatilla Chamberlin \& Ivie, 1941 by having the median plate wider than long (Fig. 3c). Males of $C$. angelena differ from $C$. nita Chamberlin \& Ivie, 1941 by having the dorsal part of the RTA occupying more than half the tibia length; from $C$. arizonica and $C$. californica by having the projections of the conductor shorter and thinner; from $C$. umatilla by the less concave distal edge of RTA; and from $C$. restricta and $C$. saylori by having a less curved ventral projection on the conductor (Fig. 3a, b).

Description.-Male (CIDA 91,793): Coloration: Carapace yellow, longitudinal symmetrical dark bands irregularly expressed. Ocular region brown. Chelicerae and condyles brown. Endites and labium light brown with white tip. Sternum yellow. Legs yellow, metatarsus-tarsus light brown. Opisthosoma yellow with light brown spots. Spinnerets yellow.

Habitus: Total length 7.13. Carapace length 3.88, width 2.75 , cephalic region width 1.43 , ocular region width 0.71 . Eye diameter: AME 0.15, ALE 0.25, PME 0.13, PLE 0.17. Distance between eyes: AME-AME 0.06, AME-ALE 0.04, AME-PME 0.15, ALE-PLE 0.06, ALE-ALE 0.33, PME-PME 0.12 , PME-PLE 0.13. Clypeus height 0.23 . Chelicerae with three promarginal teeth and two retromarginal teeth; basal segment length 1.48, fang length 1 . Labium wider than long $(0.52 / 0.43)$. Endites slightly convergent (distance at their base compared to their tips $0.52 / 0.33$ ). Sternum longer than wide (1.86/1.62). Opisthosoma longer than wide (3.38/2.38). ALS separated by their basal diameter $(0.3 / 0.3)$, PLS with distal segment longer than basal segment $(0.39 / 0.27)$.

Legs: Length: I- femur 3.25/ patella-tibia 3.75/ metatarsus $3 / \operatorname{tarsus} 2.13$; II- 3.13/ 3.5/3.13/ 2.13; III- 3.13/3.63/ 3.5/ 1.88; IV- $4 / 4.75 / 4.88 / 2.5$.

Spination: Femur dorsal I- 1-3-3/ II- 1-3-3/ III- 1-3-3/ IV- 12-3; patella I- dorsal $1-1 /$ prolateral $1 /$ retrolateral 0 ; II- 1-1/ 1 / 0 ; III- 1-1/ 1/ 1; IV- 1-1/ 1/ 1; tibia I- dorsal 0/ ventral 2-2-2/ prolateral 1-1-0/ retrolateral 0 ; II- 0/ 1-2-2/ 1-1-0/ 0 ; III- 1-1-0/ 1-2-2/ 1-1-0/ 1-1-0; IV- 1-1-0/ 2-2-2/ 1-1-0/ 1-1-0; metatarsus I$0 / 2-2-2 / 1-0-1 / 0-0-1$; II- 0-0-1/ 2-2-2/ 1-0-1/ 0; III- 2-1-2/ 2-2-
2/ 0-1-1/ 0-1-1; IV- 3-2-2/ 2-1-2-2/ 0-1-1/ 0-0-1. Number of trichobothria on tarsus: I- 7, II- 7, III- 7, IV- 7.

Pedipalp: Number of dorsal spines: femur 2, tibia 4. Cymbium length 1.39, width 0.7. Embolus almost straight. Fulcrum at the base of embolus. Conductor with two projections, the ventral one with ectal border almost straight and supporting the embolus. RTA covering the entire length of tibia with dorsal projection flattened longitudinally (Figs. $2 \mathrm{a}, \mathrm{c}, \mathrm{e}, 3 \mathrm{a}, \mathrm{b})$.

Distribution.-California (USA) and Baja California (Mexico).

\section{Genus Hololena Chamberlin \& Gertsch, 1929}

Hololena Chamberiin \& Gertsch, 1929: 105.

Type species.-Hololena mimoides (Chamberlin, 1919), by original designation.

Diagnosis.-Hololena is diagnosed by the following characters in combination: male pedipalp with sinuous embolus that rests on a membranous fulcrum; conductor with two projections (Fig. 4a); RTA covering the entire tibia length; distal projection of RTA with a tooth-shaped subprocess (Fig. $4 \mathrm{e}$ ); and basal projection of RTA with a tongue-shaped subprocess (Fig. 5a). Female epigynum with an atrium in anterior position of plate and partially divided by a septum, with spurs in posterolateral position (Fig. 5c); copulatory ducts anterior to spherical primary spermathecae; secondary spermathecae in diverticula and connected to copulatory ducts; and fertilization ducts short (Fig. 4b).

Hololena septata Chamberlin \& Ivie, 1942 (Figs. 4, 5)

Hololena septata Chamberlin \& Ivie, 1942: 214, fig. 36.

Type material.-Holotype female: E. of Pine Valley, California, USA, $32^{\circ} 50^{\prime} \mathrm{N}, 116^{\circ} 32^{\prime} \mathrm{W}$, collected in juvenile stage, 13 September 1941 (matured 6 October 1941), W. Ivie (AMNH; not examined).

Material examined.-USA: California: 1 o , San Diego Co., Naval Base Point Loma, 32 $42^{\prime} 44.06^{\prime \prime}$ N, 117 $15^{\prime} 09.04^{\prime \prime} \mathrm{W}, 27$ February 2008, Naval Base Point Loma Team (SDNHM a000798); 1 \&, same data except $32^{\circ} 41^{\prime} 09.02^{\prime \prime} \mathrm{N}$, $117^{\circ} 14^{\prime} 28.46^{\prime \prime} \mathrm{W}, 21$ December $^{2} 009$ (SDNHM a000835); 1 ㅇ, same data except $32^{\circ} 41^{\prime} 09.03^{\prime \prime} \mathrm{N}, 117^{\circ} 14^{\prime} 28.43^{\prime \prime} \mathrm{W}$ (SDNHM a000836); 1 의, same data except $32^{\circ} 41^{\prime} 45.74^{\prime \prime} \mathrm{N}$, $117^{\circ} 14^{\prime} 36.24^{\prime \prime} \mathrm{W}$ (SDNHM a000837); 1 \&, same data except $32^{\circ} 42^{\prime} 28.64^{\prime \prime} \mathrm{N}, 117^{\circ} 15^{\prime} 14.6^{\prime \prime} \mathrm{W}, 16$ November 2009 (SDNHM a000844); $1 \delta^{\sigma}$, same data except $32^{\circ} 41^{\prime} 34.42^{\prime \prime} \mathrm{N}$, $117^{\circ} 14^{\prime} 36.38^{\prime \prime} \mathrm{W}, 21$ December 2009 (SDNHM a000840); 1 o, same data except $32^{\circ} 42^{\prime} 14.88^{\prime \prime} \mathrm{N}, 117^{\circ} 14^{\prime} 51.24^{\prime \prime} \mathrm{W}$ (SDNHM a000871); 1 б, North Park, September 2008, J. Berrian (SDNHM a000814); 1 ๙, Lemon Grove, 12 December 2008, J. Berrian (SDNHM a000825); 1 \&, Balboa Park, 2-3 May 2008, J. Berrian (SDNHM a000828). MEXICO: Baja California: 1 \&, Municipality of Ensenada, Highway Ensenada-Tijuana $\mathrm{km} \mathrm{14}, 31^{\circ} 54^{\prime} 24^{\prime \prime} \mathrm{N}, 116^{\circ} 43^{\prime} 59^{\prime \prime} \mathrm{W}, 1 \mathrm{~m}, 1$ March 2010, C. Mayorga \& L. Cervantes (CARCIB 1926); 1 q, La Misión, 2 March 1997, J. Berrian (SDNHM a000818); 1 q, same data (SDNHM a000817). 
Diagnosis.-Females of $H$. septata differ from $H$. aduma Chamberlin \& Ivie, 1942, H. monterea Chamberlin \& Ivie, 1942 and $H$. sula Chamberlin \& Ivie, 1942 by having the spurs separated from each other by three times their basal width; from $H$. adnexa (Chamberlin \& Gertsch, 1929), H. altura Chamberlin \& Ivie, 1942, H. atypica Chamberlin \& Ivie, 1942, $H$. barbarana Chamberlin \& Ivie, 1942, H. curta (McCook, 1894), H. dana Chamberlin \& Ivie, 1942, H. hopi Chamberlin \& Ivie, 1942, H. lassena Chamberlin \& Ivie, 1942, H. nedra Chamberlin \& Ivie, 1942, H. oola Chamberlin \& Ivie, 1942, H. parana Chamberlin \& Ivie, 1942, H. santana Chamberlin \& Ivie, 1942, H. tentativa (Chamberlin \& Gertsch, 1929) and $H$. turba Chamberlin \& Ivie, 1942 by having spurs closer to the posterior margin of the epigynal plate; and from $H$. furcata (Chamberlin \& Gertsch, 1929), H. frianta Chamberlin \& Ivie, 1942, H. hola (Chamberlin, 1928), H. madera Chamberlin \& Ivie, 1942, H. mimoides, H. nevada (Chamberlin \& Gertsch, 1929), H. oquirrhensis (Chamberlin \& Gertsch, 1930), H. pacifica (Banks, 1896) and H. pearcei Chamberlin \& Ivie, 1942 by having the atrium rounded (Fig. 5c). Males of $H$. septata differ from $H$. adnexa, $H$. pacifica, $H$. parana, $H$. sidella Chamberlin \& Ivie, 1942 and $H$. tulareana Chamberlin \& Ivie, 1942 by having both projections of the conductor more separated; from $H$. altura, $H$. lassena, $H$. mimoides, $H$. nedra, $H$. rabana Chamberlin \& Ivie, 1942 and $H$. santana by having a smaller tooth-shaped subprocess on the distal projection of the RTA and a larger tongue-shaped subprocess on the basal projection of the RTA; from $H$. curta, $H$. dana and $H$. tentativa by having the fulcrum smaller than the distal projection of the conductor; from $H$. frianta by having the distal projection of conductor with a tip straight; and from $H$. furcata, $H$. hola, $H$. madera, $H$. monterea, $H$. nevada, $H$. oquirrhensis, $H$. pearcei and $H$. sula by having a basal projection of the RTA with deeper ectal notch (Fig. 5a).

Description.-Male (SDNHM a000814): Coloration: Carapace yellow with a black band around the border of thoracic region and two longitudinal symmetrical dark bands on carapace, intensified by brown feathery scale-like setae. Cephalic region with two brown spots behind PME. Chelicerae dark brown. Condyles brown. Endites and labium brown with white tips. Sternum yellow with brown border. Legs yellow, tibia-metatarsus brown. Opisthosoma light brown with dorsal foliage and lateral brown spots. Spinnerets yellow.

Habitus: Total length 8.5. Carapace length 5, width 2.63, cephalic region width 1.9 , ocular region width 1.05 . Eye diameter: AME and ALE 0.21, PME 0.19, PLE 0.23. Distance between eyes: AME-AME 0.08, AME-ALE 0.08, AME-PME 0.19, ALE-PLE 0.06, ALE-ALE 0.48, PME-PME 0.15, PMEPLE 0.13. Clypeus height 0.35 . Chelicerae with three promarginal teeth and two retromarginal teeth; basal segment length 1.9 , fang length 0.95 . Labium wider than long $(0.7 /$ 0.61). Endites slightly convergent (distance at their base compared to their tips $0.61 / 0.39)$. Sternum longer than wide (2.38/1.9). Opisthosoma longer than wide (4/2.25). ALS separated by less than their basal diameter $(0.24 / 0.3)$, PLS with distal segment shorter than basal segment $(0.3 / 0.45)$.

Legs: Length: I- femur $3.75 /$ patella-tibia $4.63 /$ metatarsus $3.63 /$ tarsus 2.25; II- 3.63/4.38/3.5/ 2.13; III- 3.5/4.38/3.5/ 2; IV- $4.13 / 5 / 4.75 / 2.38$.
Spination: Femur dorsal I- 1-2-3/ II- 1-3-3/ III- 1-3-3/ IV- 12-3; patella I- dorsal 1-1/ prolateral $1 /$ retrolateral 0 ; II- 1-1/ 1 / 0 ; III- 1-1/ 1/ 1; IV- 1-1/ 1/ 1; tibia I- dorsal 0/ ventral 2-2-2/ prolateral 1-1-0/ retrolateral 0 ; II- $0 / 1-2-2 / 1-1-0 / 0$; III- 1-1-0/ 2-2-2/ 1-1-0/ 1-1-0; IV- 1-1-0/ 2-1-2-2/ 1-1-0/ 1-1-0; metatarsus I- $0 / 2-2-2 / 0-1-1 / 0-1-1$; II- 0-0-1/ 2-2-2/ 0-1-1/ 0-1-1; III- 2-1$2 / 2-2-2 / 0-1-1 / 0-1-1$; IV- 3-2-2/ 1-1-1-2-2/ 0-1-1/ 0-0-1. Number of trichobothria on tarsus: I- 6, II- 7, III- 7, IV- 6.

Pedipalp: Number of dorsal spines: femur 3, tibia 4. Cymbium length 1.5, width 1. Embolus sinuous. Conductor with two projections with distal one placed in median part of bulb. Fulcrum supporting the embolus with conductor. RTA with distal and basal projections. Basal projection strongly notched ectally with a tongue-shaped subprocess (Figs. 4a, c, e, 5a, b).

Variation.-Females from Baja California have a less conspicuous septum on atrium of epigynal plate and copulatory ducts less curved (Fig. 4b).

Distribution.-California (USA) and Baja California (Mexico).

Genus Rothilena Maya-Morales \& Jiménez, 2013

Rothilena Maya-Morales \& Jiménez, 2013: 443.

Type species.-Rothilena griswoldi Maya-Morales \& Jiménez, 2013, by original designation.

Diagnosis. - Rothilena is diagnosed by the following characters in combination: male pedipalp with a sinuous embolus; conductor with three short projections (Fig. 6c); RTA covering the entire tibia length (Fig. 7b); and distal and dorsal projections of RTA with dorsal and ventral excavations, respectively (Fig. 6e). Epigynum with an atrium in anterior position of plate; hoods covering the copulatory openings; copulatory ducts short; primary spermathecae spherical; secondary spermathecae in diverticula and connected to copulatory ducts; and fertilization ducts short (Fig. 6b, d, f).

Rothilena cochimi Maya-Morales \& Jiménez, 2013

Rothilena cochimi Maya-Morales \& Jiménez, 2013: 453, figs. 1-3, $20,21,32-41$

Record.-MEXICO: Baja California Sur: Municipality of Comondú, San José de Comondú (Maya-Morales \& Jiménez 2013: 453)

New records.-MEXICO: Baja California Sur: 1 đo, Municipality of Loreto, San Javier, $25^{\circ} 52^{\prime} 16.4^{\prime \prime} \mathrm{N}, 111^{\circ} 32^{\prime} 46.4^{\prime \prime} \mathrm{W}, 415$ $\mathrm{m}$, hand collecting, 1 July 2013, C. Palacios \& J. Maya (CARCIB 3690); 1 \%, same data (CARCIB 3691); 1 \%, same data (CARCIB 3692); 1 ㅇ, same data (CARCIB 3756); 1 \%, Cuevas Pintas, $25^{\circ} 58^{\prime} 41.4^{\prime \prime} \mathrm{N}, 111^{\circ} 27^{\prime} 54.6^{\prime \prime} \mathrm{W}, 206 \mathrm{~m}$, hand collecting, 2 July 2013, C. Palacios \& J. Maya (CARCIB 3693); 1 의, same data (CARCIB 3694). All specimens were collected as juveniles and reared to maturity in the laboratory September-October 2013.

Rothilena pilar Maya-Morales \& Jiménez, 2013

Rothilena pilar Maya-Morales \& Jiménez, 2013: 457, figs. 4-6, 42-51.

Record.-MEXICO: Baja California Sur: Municipality of La Paz, El Pilar (Maya-Morales \& Jiménez 2013: 457).

New records.-MEXICO: Baja California Sur: 1 , Municipality of La Paz, Rancho El Camarón, 2419'11.6"N, $110^{\circ} 40^{\prime} 6.9^{\prime \prime} \mathrm{W}, 17 \mathrm{~m}$, hand collecting, 29 June 2013, C. Palacios and J. Maya (CARCIB 3687); 1 ऽ, same data 

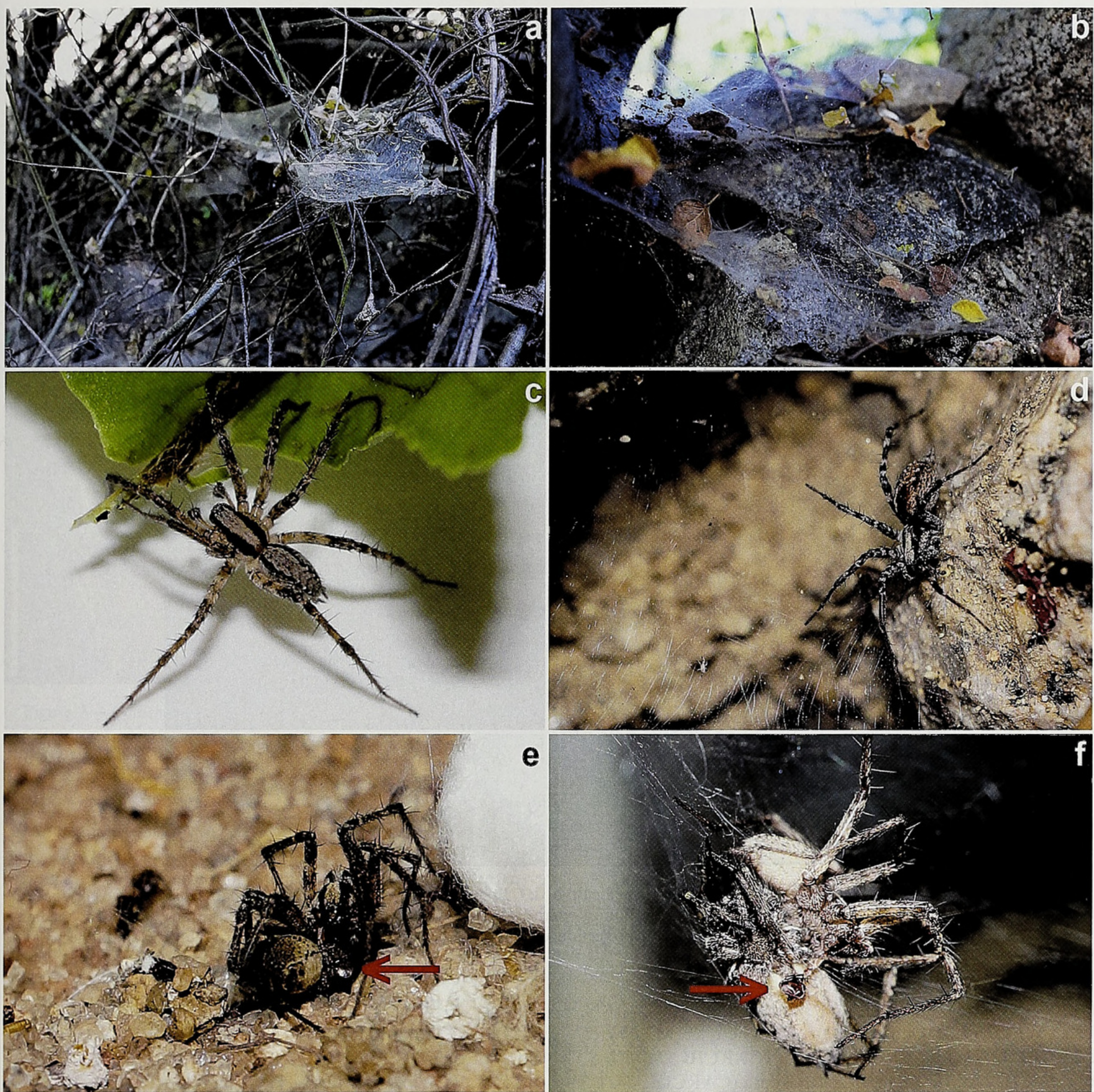

Figure 1.-Agelenids from the Baja California Peninsula (Mexico). a, c, e. Cabolena huiztocatl sp. nov. (Punta San Pedro, Baja California Sur). a. Web on vegetation. c. Male. e. Mating pair. b, d. Rothilena sudcaliforniensis (Sierra Las Cacachilas, Baja California Sur). b. Web on rocks. d. Female on web. f. $R$. cochimi (San Javier, Baja California Sur), mating pair. Arrows indicate expanded bulb.

(CARCIB 3688); 1 ó, same data (CARCIB 3689). All specimens were collected as juveniles and reared to maturity in the laboratory 1-12 September 2013.

Rothilena sudcaliforniensis Maya-Morales \& Jiménez, 2013 (Figs. 1b, d, 6, 7)

Rothilena sudcaliforniensis Maya-Morales \& Jiménez, 2013: 461, figs. 58-63.
Type material.-Holotype female: Municipality of $\mathrm{La} \mathrm{Paz,}$ Biosphere Reserve Sierra La Laguna, Cañón La Burrera, Baja California Sur, Mexico, 1 January 1988, A. Cota (CARCIB 56).

New material examined.-MEXICO: Baja California Sur: 1 đ. Municipality of La Paz, El Comitán, Dr. Laura Arriaga Cabrera Biological Station, $24^{\circ} 05^{\prime} \mathrm{N}, 110^{\circ} 21^{\prime} \mathrm{W}$, pitfall trap, 29 September 1992, J.G. Navarrete (CARCIB 3427); 1 o, same 

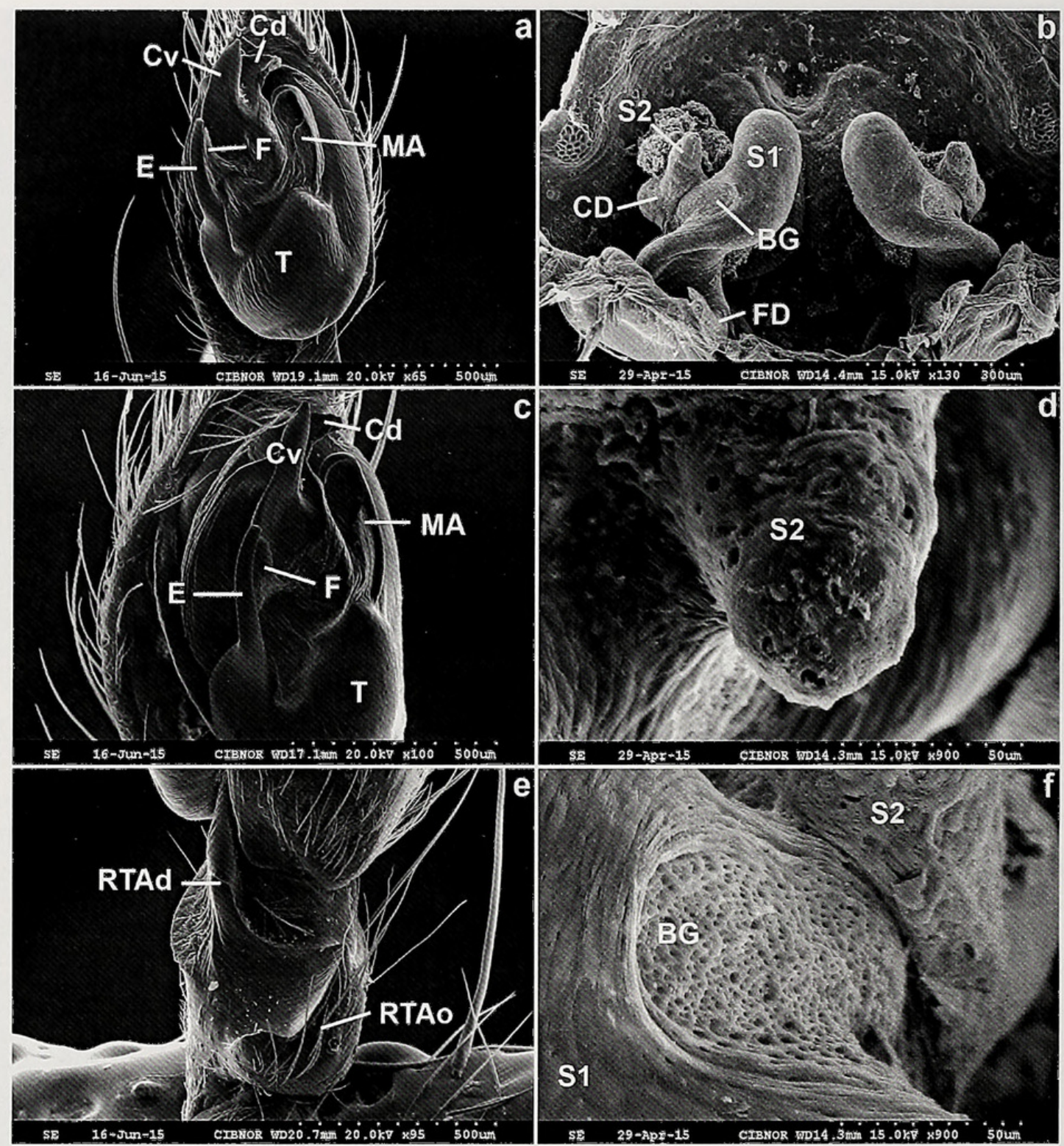

Figure 2.-Calilena angelena, genitalia (SEM). a, c, e. Male pedipalp b, d, f. Epigynum. Abbreviations: BG, Bennett's glands; CD, copulatory ducts; $\mathrm{Cd}$, dorsal projection of conductor; $\mathrm{Cv}$, ventral projection of conductor; $\mathrm{E}$, embolus; $\mathrm{F}$, fulcrum; FD, fertilization ducts; MA, median apophysis; RTAd, distal projection of RTA; RTAo, dorsal projection of RTA; S1, primary spermathecae; S2, secondary spermathecae; T, tegulum.

data (CARCIB 3428); 1 o, 1 \%, same data except $24^{\circ} 07^{\prime} \mathrm{N}$, $110^{\circ} 25^{\prime} \mathrm{W}, 20 \mathrm{~m}, 4$ October 2005, G. Nieto \& M. Correa (CARCIB 3739); 1 ๙ 1 \%, same data (CARCIB 3740); 1 \%, same data (CARCIB 3741); 1 ઈ, same data (CARCIB 3742); 3 ธิ, same data (CARCIB 3743); 1 đ, same data except 6 November 2005 (CARCIB 3744); 1 б, same data (CARCIB 3745); 1 \&, Sierra Las Cacachilas, Rancho El Chivato, $24^{\circ} 02^{\prime} 18.7^{\prime \prime} \mathrm{N}, 110^{\circ} 03^{\prime} 20.0^{\prime \prime} \mathrm{W}, 354 \mathrm{~m}$, hand collecting, 2 November 2013, M.L. Jiménez \& J. Maya (CARCIB 3695); 1 \&, same data except $24^{\circ} 02^{\prime} 41.9^{\prime \prime} \mathrm{N}, 110^{\circ} 04^{\prime} 11.4^{\prime \prime} \mathrm{W}, 487 \mathrm{~m}, 5$

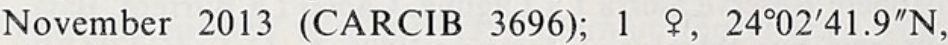
$110^{\circ} 04^{\prime} 8.8^{\prime \prime} \mathrm{W}, 478 \mathrm{~m}, 17$ October 2014, C. Palacios, J. Maya \& D. Vega (CARCIB 3758); 1 \&, same data except $24^{\circ} 02^{\prime} 46.1^{\prime \prime} \mathrm{N}, 110^{\circ} 04^{\prime} 4.6^{\prime \prime} \mathrm{W}, 470 \mathrm{~m}, 21$ October 2014 (CARCIB 3760); 1 o, same data except $24^{\circ} 02^{\prime} 41.9^{\prime \prime} \mathrm{N}$, $110^{\circ} 04^{\prime} 8.8^{\prime \prime} \mathrm{W}, 478 \mathrm{~m}, 17$ October 2014 (CARCIB 3763); 1 \&, Los Pisos, $24^{\circ} 07^{\prime} 19.3^{\prime \prime} \mathrm{N}, 110^{\circ} 03^{\prime} 49.1^{\prime \prime} \mathrm{W}, 551 \mathrm{~m}, 19$
October 2014, C. Palacios, J. Maya \& D. Vega (CARCIB 3759); 1 \%, same data (CARCIB 3761); 1 \%, Arroyo Dos Hermanos, $24^{\circ} 03^{\prime} 35.6^{\prime \prime} \mathrm{N}, 110^{\circ} 03^{\prime} 44.8^{\prime \prime} \mathrm{W}, 403 \mathrm{~m}, 20$ October 2014, C. Palacios, J. Maya \& D. Vega (CARCIB 3762); 1 đ, El Triunfo, $23^{\circ} 48^{\prime} 15.7^{\prime \prime} \mathrm{N}, 110^{\circ} 06^{\prime} 43.7^{\prime \prime} \mathrm{W}, 468 \mathrm{~m}$, hand collecting, 18 March 2015, M.L. Jiménez, C. Palacios \& J. Maya (CARCIB 3791); 1 ơ, same data except $23^{\circ} 48^{\prime} 4.4^{\prime \prime} \mathrm{N}$, $110^{\circ} 06^{\prime} 24.7^{\prime \prime} \mathrm{W}, 484 \mathrm{~m}$ (CARCIB 3793); 1 \%, same data (CARCIB 3794); 1 \%, same data (CARCIB 3795); 1 \%, same data (CARCIB 3796); 1 ऽ, same data (CARCIB 3797); 1 \%, same data (CARCIB 3824).

Diagnosis.-Males of $R$. sudcaliforniensis differ from $R$. griswoldi by having a dorsal projection of the RTA ending in a sharp tip (Fig. 6a) and from $R$. cochimi and $R$. pilar by having a dorsal projection of the RTA that is longer and directed ventrally (Fig. 7b). Females differ from all other species by having hoods that are as long as wide. 

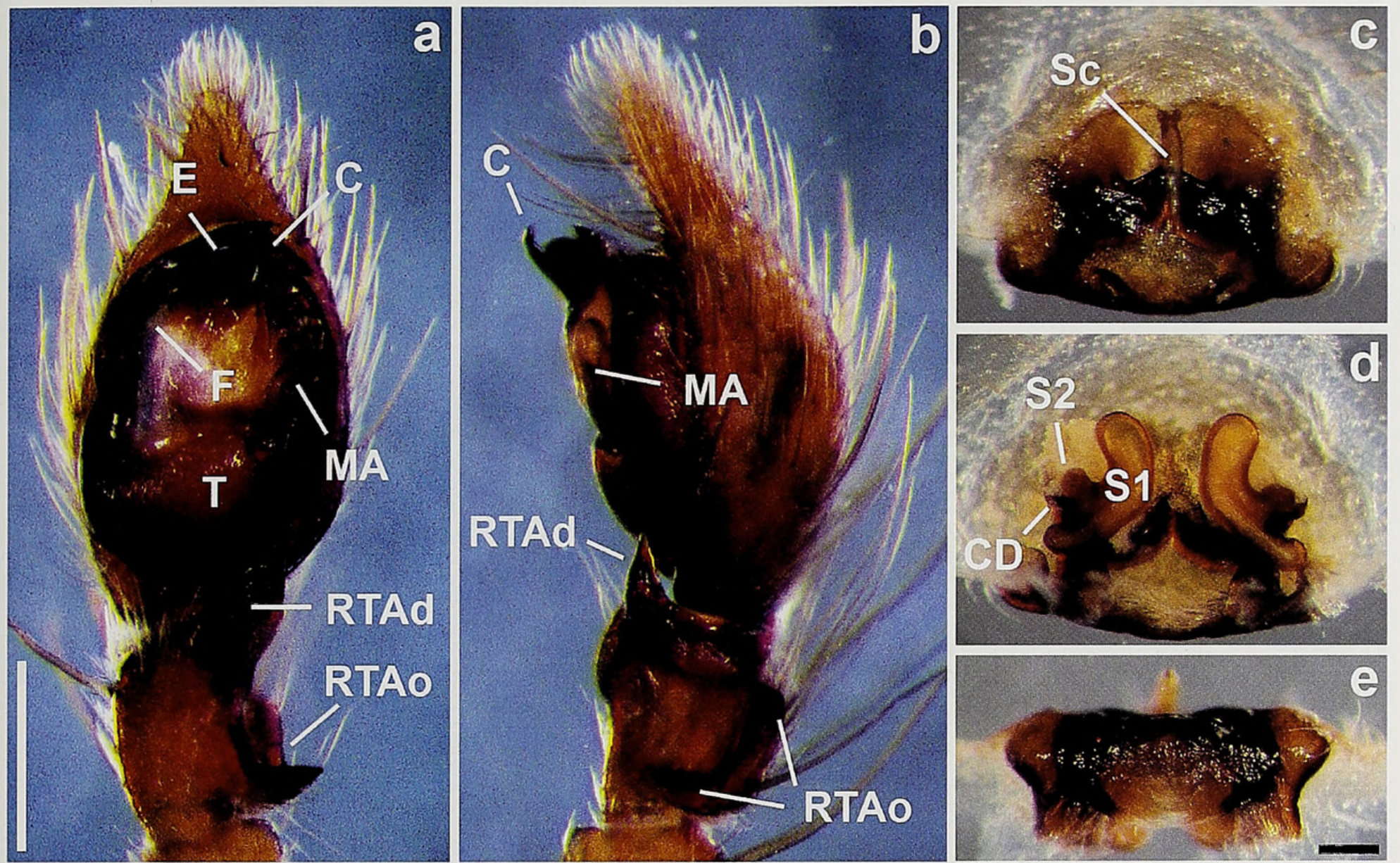

Figure 3.-Calilena angelena, genitalia. a, b. Male pedipalp. c-e. Epigynum. a, c. Ventral view. b. Retrolateral view. d. Dorsal view. e. Posterior view. Abbreviations: CD, copulatory ducts; E, embolus; F, fulcrum; FD, fertilization ducts; MA, median apophysis; RTAd, distal projection of RTA; RTAo, dorsal projection of RTA; Sc, scape; S1, primary spermathecae; S2, secondary spermathecae; T, tegulum. Scale bars: $\mathrm{a}=0.5 \mathrm{~mm} ; \mathrm{e}=0.15 \mathrm{~mm}$.

Description.-Male (CARCIB 3427): Coloration: Carapace light brown with a black band around the border of thoracic region and two longitudinal symmetrical dark bands, intensified by brown feathery scale-like setae. Chelicerae and condyles brown. Endites and labium light brown with white tip. Sternum yellow with brown border. Legs yellow with three rings on femur and one on tibia. Opisthosoma light brown, three anterior brown spots, four pairs of lateral light spots and lateral brown lines. Spinnerets yellow, basal segment of PLS with dark brown spots.

Habitus: Total length 6.38. Carapace length 2.88, width 2.13 , cephalic region width 1.06 , ocular region width 0.61 . Eye diameter: AME, ALE and PLE 0.15, PME 0.13. Distance between eyes: AME-AME 0.02, AME-ALE 0.04, AME-PME 0.12 , ALE-PLE 0.02, ALE-ALE 0.25, PME-PME 0.08, PMEPLE 0.08. Clypeus height 0.23 . Chelicerae with three promarginal teeth and two retromarginal teeth; basal segment length 1.15 , fang length 0.85 . Labium wider than long $(0.45 /$ 0.33 ). Endites slightly convergent (distance at their base compared to their tips $0.45 / 0.27$ ). Sternum longer than wide (1.43/1.24). Opisthosoma longer than wide (3.13/1.75). ALS separated by less than their basal diameter $(0.21 / 0.27)$, PLS with distal segment slightly longer than basal segment $(0.45 /$ $0.33)$.
Legs: Length: I- femur $2.62 /$ patella-tibia $3.31 /$ metatarsus $2.62 /$ tarsus 1.77; II- 2.62/3.15/2.38/ 1.62; III- 2.77/ 3.08/ 2.92/ 1.69; IV- 3.31/ 3.85/4.08/2.08.

Spination: Femur dorsal I- 1-2-2/ II- 1-3-2/ III- 1-3-2/ IV- 12-2; patella I- dorsal $1-1 /$ prolateral $1 /$ retrolateral 0 ; II- $1-1 / 1$ / 0 ; III- 1-1/ 1/ 1; IV- 1-1/ 1/ 1; tibia I- dorsal 0/ ventral 2-2-2/ prolateral 1-1-0/ retrolateral 0; II- 0/ 2-2-2/ 1-1-0/ 0; III- 1-1-0/ 1-2-2/1-1-0/ 1-1-0; IV- 1-1-0/ 2-2-2/ 1-1-0/ 1-1-0; metatarsus I$0 / 2-2-2 / 0-1-1 / 0$; II- 0-0-1/ 2-2-2/ 0-1-1/ 0; III- 2-0-2/ 2-2-2/0$1-1 / 0-1-1$; IV- 3-2-2/ 1-1-1-2-2/ 0-1-1/ 0-1-1. Number of trichobothria on tarsus: I- 6, II- 6, III- 6, IV- 6 .

Pedipalp: Number of dorsal spines: femur 2, tibia 4. Cymbium length 1.09 , width 0.64. Embolus sinuous. Conductor with distal and mesal projections beak-shaped, ectal projection rounded. Dorsal projection of RTA ends in a sharp tip and is directed ventrally; anterior margin is straight (Figs. 6a, c, e, 7).

Variation.-The epigynum presents slight differences between localities: the copulatory ducts may be closer to each other in females from El Triunfo and San Antonio; secondary spermathecae are directed laterally in specimens from Sierra La Laguna, El Triunfo, San Antonio, and El Comitán, and anteriorly in specimens from Sierra Las Cacachilas (Fig. 6b, f). 

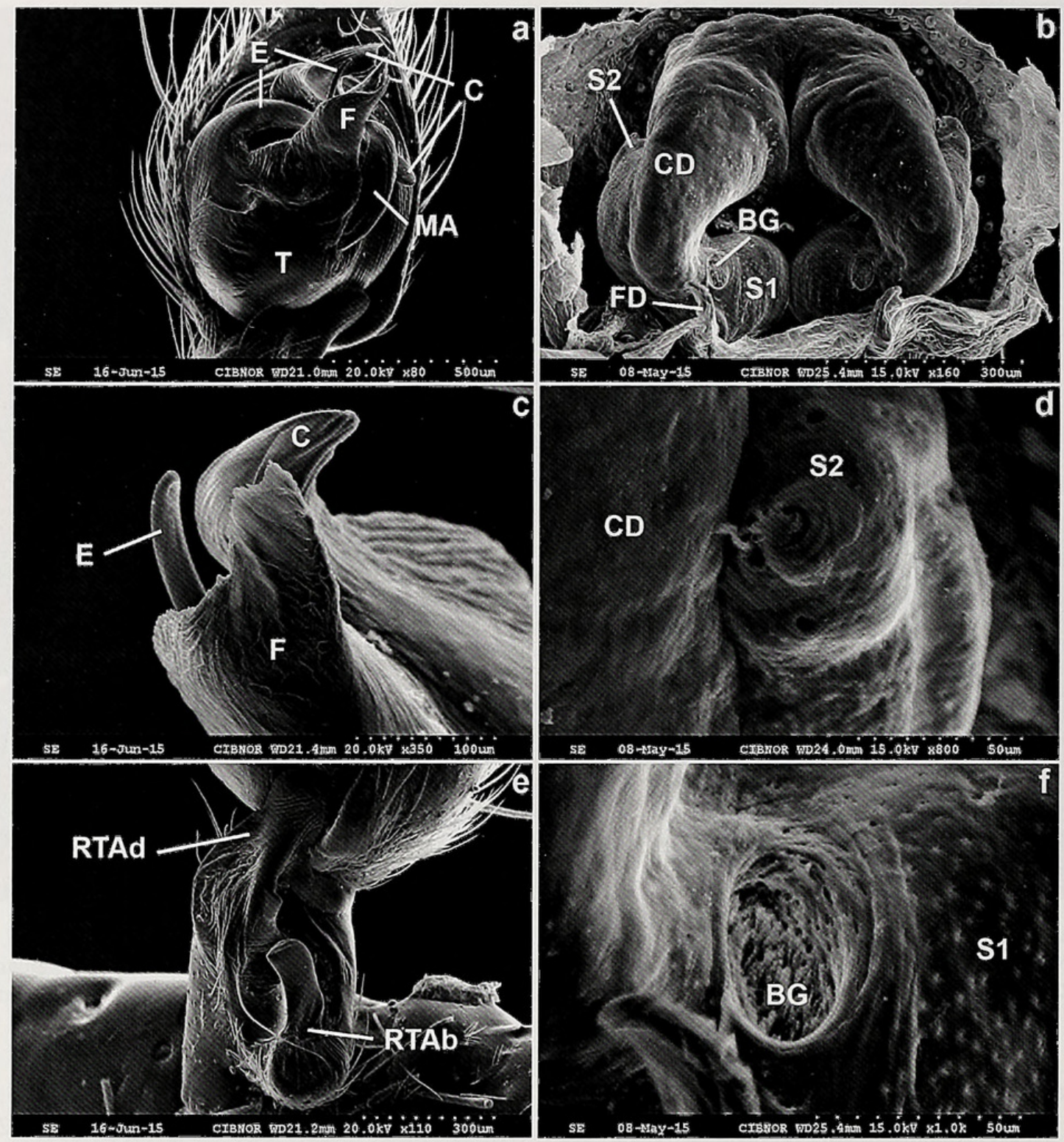

Figure 4.-Hololena septata, genitalia (SEM): a, c, e. Male pedipalp. b, d, f. Epigynum. Abbreviations: BG, Bennett's glands; CD, copulatory ducts; Cd, dorsal projection of conductor; $\mathrm{Cv}$, ventral projection of conductor; E, embolus; F, fulcrum; FD, fertilization ducts; MA, median apophysis; RTAb, basal projection of RTA; RTAd, distal projection of RTA; S1, primary spermathecae; S2, secondary spermathecae; T, tegulum.

Habitat.-Deciduous lowland forest and desert shrubland. The specimens were found on the ground, between rocks and low vegetation (Fig. 1b, d).

Distribution.-Baja California Sur (Mexico).

Genus Bajacalilena Maya-Morales \& Jiménez gen. nov. http://zoobank.org/?lsid=urn:lsid:zoobank.

org:act:60362154-56FF-49D4-BA78-3AB0A9AB32EF

Type species.-Bajacalilena clarki sp. nov.

Etymology. - The generic name is derived from the region where the species of the genus are found and are potentially endemic. The gender is feminine.

Diagnosis.-Bajacalilena gen. nov. is diagnosed by the following characters in combination: male pedipalp with a coiled embolus supported by a membranous horseshoe-shaped conductor (Fig. 9a); and RTA covering the entire tibia length with distal and dorsal projections. Epigynum with the atrium as a deep cavity and spurs in lateral position (Fig. 8a, b); copulatory openings in lateral position; copulatory ducts larger than primary spermathecae and in two parts (Figs. 8c, 9b); primary spermathecae spherical, adjacent (Fig. 8e) or separated by less than their width (Fig. 8d); secondary spermathecae small and connected to copulatory ducts (Fig. $9 \mathrm{~b}, \mathrm{f}$ ); and fertilization ducts short (Fig. 8f).

Bajacalilena gen. nov. differs from Eratigena Bolzern, Burckhardt \& Hänggi, 2013 and Tegenaria by having strongly procurved eye rows in frontal view. Bajacalilena gen. nov. shares with Agelenopsis, Barronopsis, Melpomene O. P.-Cambridge, 1898, and Tortolena Chamberlin \& Ivie, 1941 a strongly modified embolus, and like Agelenopsis, Barronopsis and Tortolena, Bajacalilena gen. nov. has a coiled embolus (Fig. 9c). However, Bajacalilena gen. nov. differs from these genera by the shape of the median apophysis, which is not 

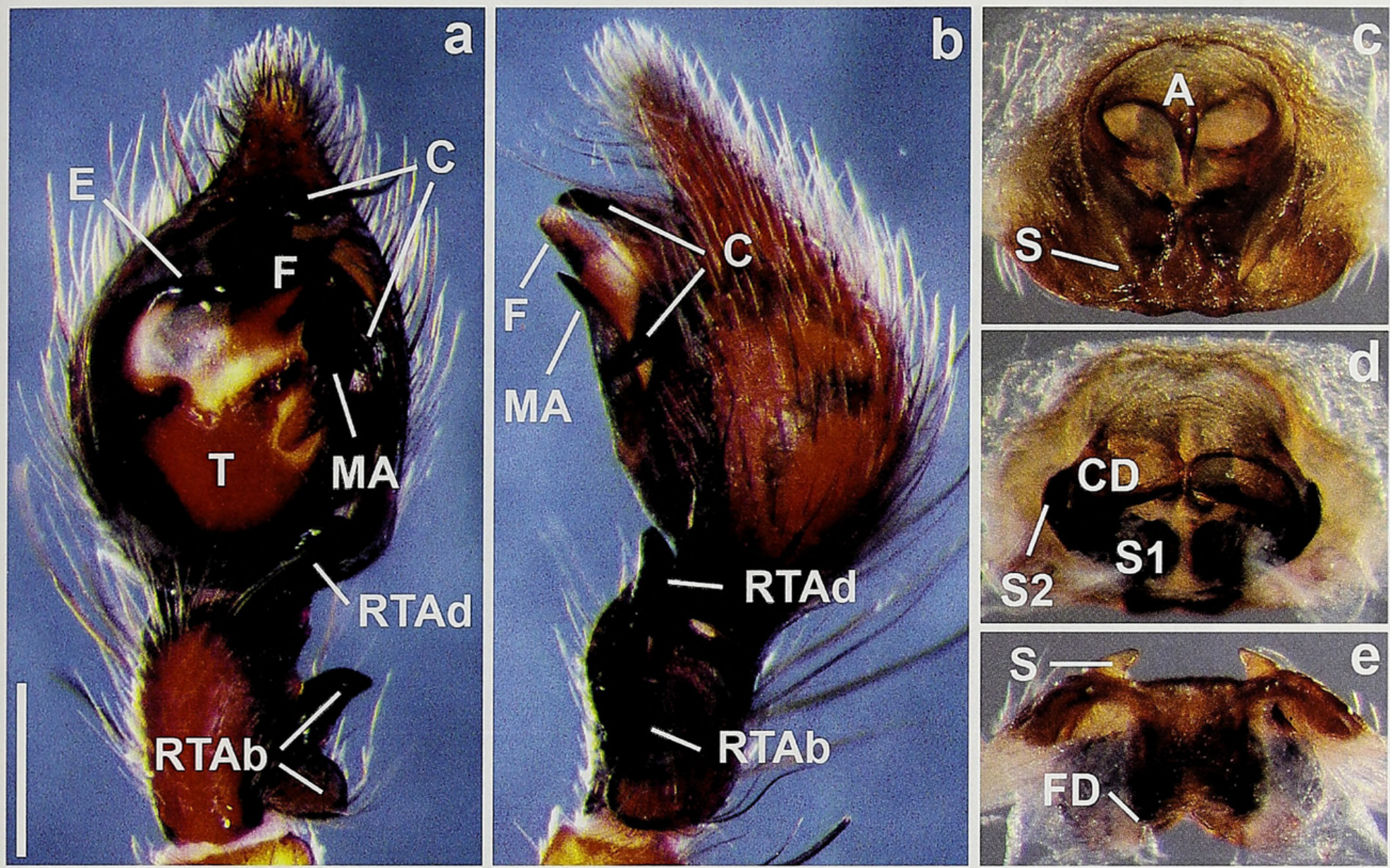

Figure 5.-Hololena septata, genitalia. a, b. Male pedipalp. c-e. Epigynum. a, c. Ventral view. b. Retrolateral view. d. Dorsal view. e. Posterior view. Abbreviations: A, atrium; CD, copulatory ducts; E, embolus; F, fulcrum; FD, fertilization ducts; MA, median apophysis; RTAb, basal projection of RTA; RTAd, distal projection of RTA; S, spurs; S1, primary spermathecae; S2, secondary spermathecae; T, tegulum. Scale bar = $0.5 \mathrm{~mm}$.

reduced (Fig. 9a), and by the absence of a tegular lateral process on the male pedipalp. Bajacalilena gen. nov. differs from Hoffmannilena Maya-Morales \& Jiménez, 2016 by the absence of a tegular median process (as in Maya-Morales \& Jiménez 2016: fig. 114) and the poorly sclerotized epigynum (as in Maya-Morales \& Jiménez 2016: fig. 116); from Novalena by the absence of a tegular median process on the male pedipalp (as in Maya-Morales \& Jiménez 2016: fig. 87) and having the primary spermathecae spherical; from Cabolena gen. nov. by having the embolus coiled and primary spermathecae spherical; from Lagunella gen. nov. by having the embolus originating from the median part of the tegulum and the copulatory ducts connected anteriorly to primary spermathecae; from Calilena by the absence of both a membranous fulcrum on the male pedipalp (as in Fig. 3a) and a scape on the epigynum (Fig. 3c); from Hololena by having the embolus supported by the conductor only and the absence of a median septum on the epigynal atrium (Fig. 5c); from Rualena by the absence of a fulcrum on the male pedipalp (as in Maya-Morales \& Jiménez 2016: fig. 43) and having the atrium wider than long; from Rothilena by having the conductor with two projections and no hoods on the atrium (as in Maya-Morales \& Jiménez 2013: fig. 26); and from Callidalena gen. nov. by having the embolus coiled and the atrium as an anterior deep cavity.

Description.-Medium sized spiders, 5-11 in total length. Eight eyes. Both eye rows strongly procurved in frontal view. Feathery scale-like setae present on carapace, opisthosoma, pedipalps and legs. Carapace with two longitudinal symmetrical dark bands intensified by feathery setae, a black band around the border of thoracic region, and a clear median band wider on cephalic region. Chelicerae with three promarginal teeth and two retromarginal teeth. Sternum longer than wide. Pedipalp femur with two dorsal spines. Legs with spines. Leg IV the longest. Rings present on femur, patella and tibia. Patella-tibia I longer than carapace in males and usually shorter than carapace in females. Patella I and II with two dorsal spines and one prolateral spine, patella III and VI with two dorsal spines, one prolateral spine, and one retrolateral spine. Leg tarsi with five to six trichobothria. Capsulate tarsal organ in distal position of trichobothrial row. Opisthosoma oval with dorsal foliate pattern and/or posterior chevrons. Colulus divided, represented by few hairs. PLS longest with distal segment as long as or slightly longer than basal segment. Male pedipalp with a distinct coiled embolus supported by a conductor which is membranous and horseshoe-shaped (Fig. 10a). Median apophysis is an elongated, curved membrane 


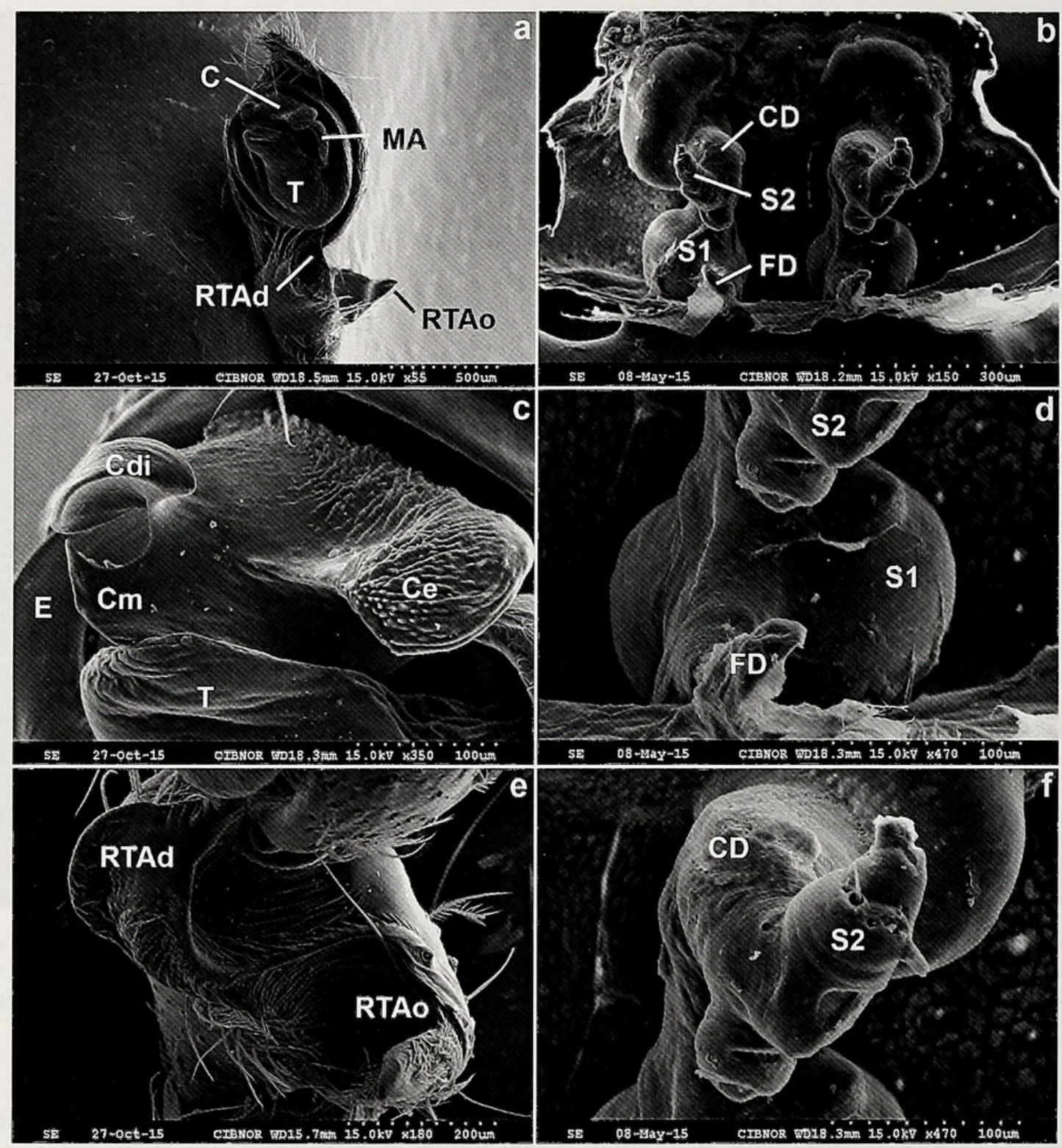

Figure 6.-Rothilena sudcaliforniensis, genitalia (SEM). a, c, e. Male pedipalp. b, d, f. Epigynum. Abbreviations: CD, copulatory ducts; Cdi, distal projection of conductor; $\mathrm{Ce}$, ectal projection of conductor; $\mathrm{Cm}$, mesal projection of conductor; E, embolus; FD, fertilization ducts; MA, median apophysis; RTAd, distal projection of RTA; RTAo, dorsal projection of RTA; S1, primary spermathecae; S2, secondary spermathecae; $\mathrm{T}$, tegulum.

(Fig. 9a). RTA covering the entire tibia length with distal and dorsal projections (Fig. 10c); tibia also with posterodorsal apophysis (Fig. 9b). Epigynal plate wider than long (Fig. 8a). Atrium is a strongly deep cavity without divisions, on anterior part of plate. Lateral hyaline spurs present (Fig. 8b). Copulatory openings at lateral position. Copulatory ducts anterior to spermathecae (Fig. 8d). Spermathecae composed by primary spermathecae and secondary spermathecae. Primary spermathecae spherical (Fig. 9d). Secondary spermathecae are small blind receptacles (diverticula) with primary pores and connected to copulatory ducts (Fig. 9b, f). Fertilization ducts short, originating from the posterior part of epigynum (Fig. 8f).

Distribution.-Bajacalilena gen. nov. is distributed in Mexico in the States of Baja California and Baja California Sur (Fig. 23a).
Included taxa.-Two species: $B$. bolzerni sp. nov. and $B$. clarki sp. nov.

Bajacalilena bolzerni Maya-Morales \& Jiménez sp. nov. http://zoobank.org/?lsid=urn:lsid:zoobank. org:act:B9D5627B-54AE-40F6-AD71-CBD98866D19C (Figs. 8a, c, e, 23a)

Type material.-Holotype female: Municipality of Ensenada, $3.2 \mathrm{~km} \mathrm{~W}$. of Ejido Morelos, Baja California, Mexico, 28 December 1978, D. Weissman, R. Love, V. Lee \& C. Mullinex (CASENT 9048907). Paratype female: MEXICO: Baja California Sur: Municipality of Mulegé, Isla Natividad, 5-6 June 1945, B.F. Osorio (AMNH).

Etymology.-The specific name is a patronym in honor of Angelo Bolzern for his contribution to systematics of Agelenidae. 


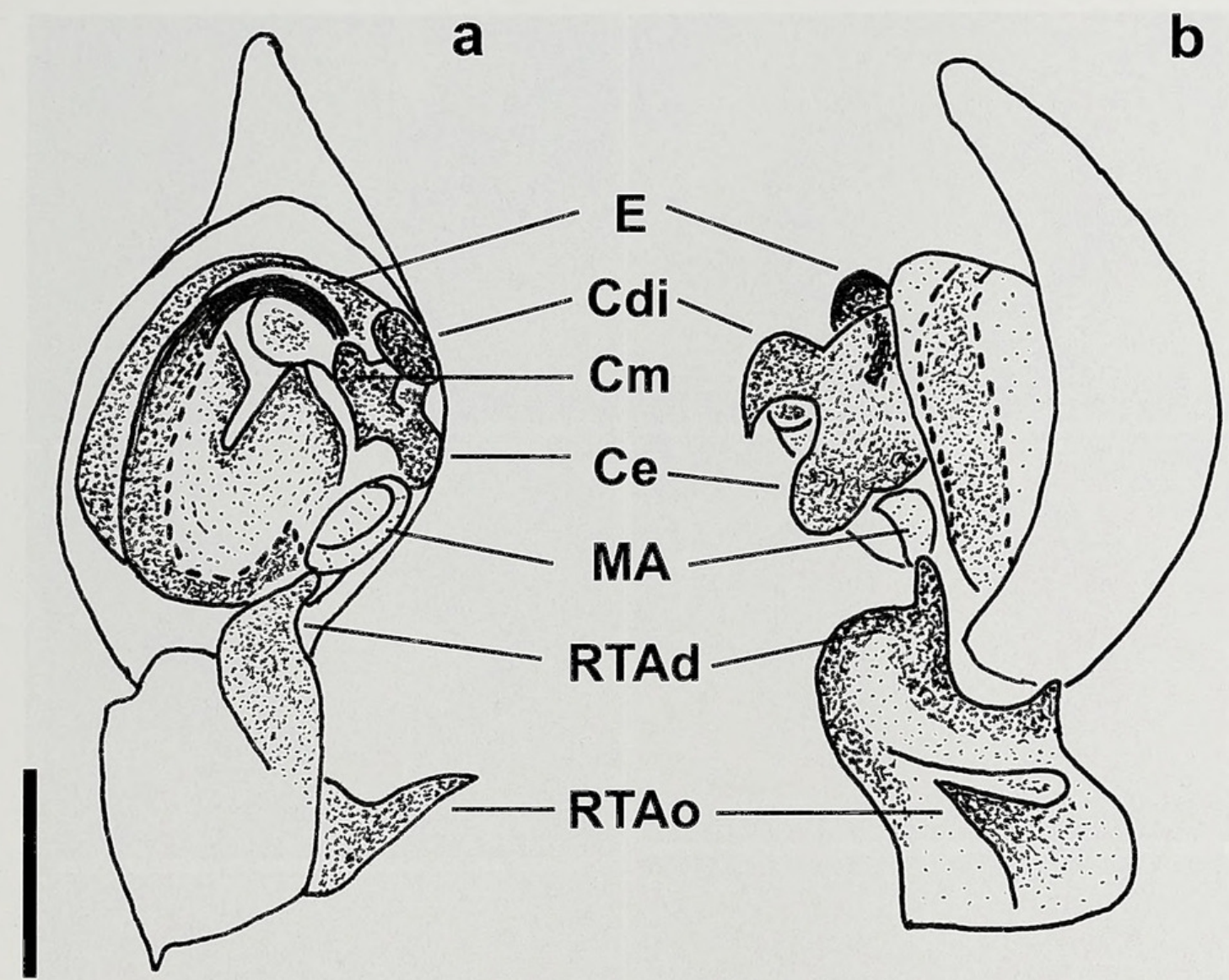

Figure 7.-Rothilena sudcaliforniensis, male pedipalp. a. Ventral view. b. Retrolateral view. Abbreviations: Cdi, distal projection of conductor; $\mathrm{Ce}$, ectal projection of conductor; $\mathrm{Cm}$, mesal projection of conductor; E, embolus; MA, median apophysis; RTAd, distal projection of RTA; RTAo, dorsal projection of RTA. Scale bar $=0.35 \mathrm{~mm}$.

Diagnosis.-Bajacalilena bolzerni differs from B. clarki sp. nov. by having the primary spermathecae adjacent (Fig. 8e) and copulatory ducts with anterior extensions (Fig. 8c).

Description.-Female (holotype): Coloration: Carapace yellow. Chelicerae light brown. Condyles greyish. Endites and labium yellow with white tips and small brown spots. Sternum yellow with brown border and four pairs of brown spots. Legs yellow. Three rings on femur, one on patella, and two on tibia. Opisthosoma orange with an anterior reddish spot, seven pairs of white spots, and several lateral brown spots. Spinnerets yellow, PLS with black borders on basal segments.

Habitus: Total length 7. Carapace length 3.13 , width 2 , cephalic region width 1.24 , ocular region width 0.67 . Eye diameter: AME, ALE and PLE 0.15, PME 0.13. Distance between eyes: AME-AME 0.04, AME-ALE 0.04, AME-PME 0.13, ALE-PLE 0.06, ALE-ALE 0.29, PME-PME 0.08, PMEPLE 0.08. Clypeus height 0.25. Chelicerae: basal segment length 1.21 , fang length 0.6 . Labium wider than long $(0.36 /$ 0.3 ). Endites slightly convergent (distance at their base compared to their tips $0.36 / 0.3$ ). Sternum longer than wide (1.57/1.24). Opisthosoma longer than wide (4.1/2.48). ALS separated by less than their basal diameter $(0.24 / 0.3)$, PLS with distal segment slightly longer than basal segment $(0.52 /$ 0.48).

Legs: Length: I- femur 2.15/ patella-tibia 2.69/ metatarsus $1.92 /$ tarsus 1.38; II- 2.31/ 2.15/ 1.92/ 1.31; III- 2.38/ 2.46/ 2.31 / 1.31 ; IV- 3.08/3.31/ 3.46/ 2 .
Spination: Femur dorsal I- 1-2-3/ II- 1-3-3/ III- 1-3-2/ IV- 12-2; patella I- dorsal 1-1/ prolateral 1/ retrolateral 0; II- 1-1/ 1 / 0 ; III- $1-1 / 1 / 1$; IV- 1-1/ 1/ 1; tibia I- dorsal 1-1-0/ ventral 2-22/ prolateral 1-1-0/ retrolateral 0; II- 1-1-0/ 1-2-2/ 1-1-0/0; III$1-1-0 / 1-1-2 /$ 1-1-0/ 1-1-0; IV- 1-1-0/ 0-2-2/ 1-1-0/ 1-1-0; metatarsus I- $0 / 2-2-2 / 0-1-1 / 0$; II- 1-0-1/ 2-2-2/ 0-1-1/ 0-0-1; III- 3-1-2/ 2-2-2/ 0-1-1/ 0-1-1; IV- 3-2-2/ 1-1-1-2-2/ 0-1-1/ 0-01. Number of trichobothria on tarsus: I- 5 , II- 5 , III- 5, IV- 5. Pedipalp: Dorsal spines on femur: 2. Prolateral spines on tibia: $1-2$.

Epigynum: Plate length 0.67 , width 1.03 . Copulatory ducts with mesal extensions and separated by their width. Primary spermathecae adjacent (Fig. 8a, c, e).

Male: Unknown.

Variation.-Total body length varies between 7 and $7.75(n$ $=2)$. Carapace length varies between 3.13 and $3.75(n=2)$. Patella-tibia I length varies between 2.69 and $4(n=2)$.

Distribution.-Baja California and Baja California Sur (Mexico) (Fig. 23a).

Bajacalilena clarki Maya-Morales \& Jiménez sp. nov. http://zoobank.org/?lsid=urn:lsid:zoobank org:act:527CBDDC-38DB-4CD6-A1DE-1EDEA1E90CD0 (Figs. 8b, d, f, 9, 10, 23a)

Type material.-Holotype male: Municipality of Ensenada, $9 \mathrm{~km}$ NW. of Rancho Santa Inés, Baja California, Mexico, $29^{\circ} 46^{\prime} \mathrm{N}, 114^{\circ} 46^{\prime} \mathrm{W}, 550 \mathrm{~m}$, pitfall trap, 19 September 1980 , 

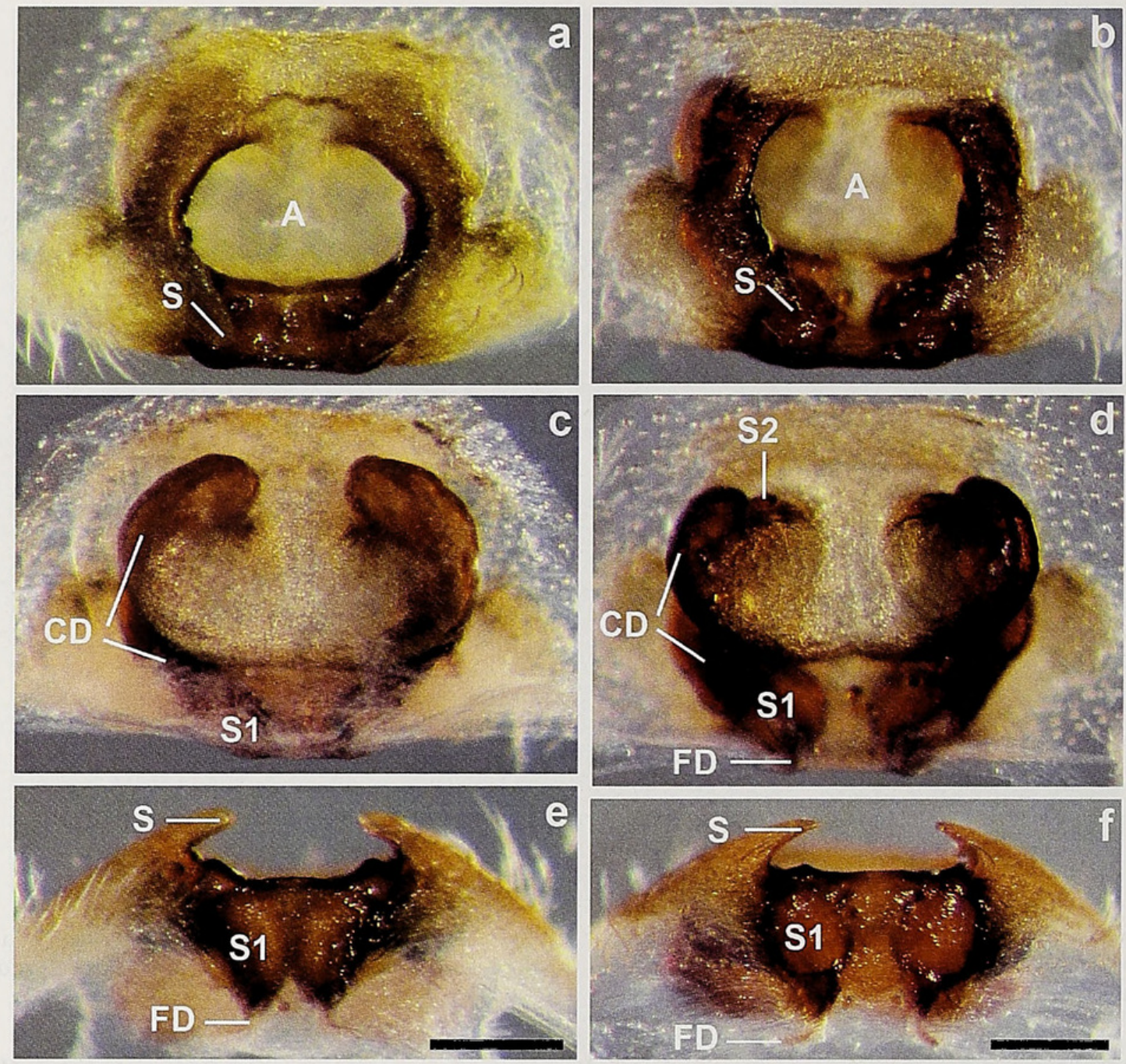

Figure 8.-Bajacalilena spp., epigyna. a, c, e. B. bolzerni sp. nov. b, d, f. B. clarki sp. nov. a, b. Ventral view. c, d. Dorsal view. e, f. Posterior view. Abbreviations: A, atrium; CD, copulatory ducts; FD, fertilization ducts; S1, primary spermathecae; S2, secondary spermathecae. Scale bars $=0.25 \mathrm{~mm}$.

W.H. Clark (CIDA 107,457) (OJSMNH). Paratypes: MEXICO: Baja California: 1 \&, Municipality of Ensenada, $66 \mathrm{~km}$ E. of El Rosario, Misión San Fernando, 11 January 1965, V. Roth (AMNH); 1 , $12.9 \mathrm{~km} \mathrm{~N}$. of Laguna Chapala, 16 April 1965, D.Q. Cavagnaro, C.E. Ross, E.S. Ross \& V.L. Vesterby (CASENT 9048906); 2 o, same data as holotype (CIDA 107,457); 1 \&, same data as holotype except 17 July 1991 - 26 May 1992 (CIDA 90,622); 5 ऽ, same data as holotype except 10 September 1980, P. Finlayson, C. Ross \& D. Webster (CIDA 107,413); 1 s, same data as holotype except 20 September 1980, C. Ross \& P. Finlayson (CIDA 107,420); 2 ऊ, 1 \%, same data as holotype except 18 September 1980, D. Webster \& D. Guyot (CIDA 107,465); 1 ๙, same data as holotype except 13 September 1980, P. Finlayson, C. Ross \& D. Webster (CIDA 107,466); 1 б, $11.7 \mathrm{~km}$ E. of El Rosario, $30^{\circ} 04^{\prime} 30^{\prime \prime} \mathrm{N}, 115^{\circ} 37^{\prime} 55^{\prime \prime} \mathrm{W}, 180 \mathrm{~m}$, pitfall trap, 7 February 1982 - 2 April 1985, W.H. Clark \& P.E. Blom (CIDA 107,428); 1 , La Ramona camp, Punta Catarina road, hand collecting on ground, 21 March 2005, J. Berrian (SDNHM a000846). Baja California Sur: 1 ๙, Municipality of Mulegé, SE. of Mesa El Tecolote, $29^{\circ} 59^{\prime} \mathrm{N}, 113^{\circ} 26^{\prime} \mathrm{W}, 120 \mathrm{~m}$, pitfall trap, $16 \mathrm{March}-8$ July 1991, W.H. Clark (ALBRCIDA 83,066); 1 $\$, 7 \mathrm{~km} \mathrm{~N}$. of Rancho El Tablón, $27^{\circ} 37^{\prime} \mathrm{N}, 113^{\circ} 21^{\prime} \mathrm{W}, 130 \mathrm{~m}$, pitfall trap, 18
March -13 July 1991, W.H. Clark (ALBRCIDA 83,086); 1 శึ, Arroyo San Lorenzo, $26^{\circ} 56^{\prime} \mathrm{N}, 113^{\circ} 47^{\prime} \mathrm{W}, 20 \mathrm{~m}$, pitfall trap, 17 March - 8 July 1991, W.H. Clark (ALBRCIDA 83,091); 1 q, foot of Sierra San Francisco, on main road, 8 April 2006, J. Berrian (SDNHM a000845).

Etymology.-The specific name is a patronym in honor of William H. Clark, collector of the holotype, for his work with terrestrial arthropods in North America.

Diagnosis.-Bajacalilena clarki differs from B. bolzerni by having the primary spermathecae separated (Fig. 9b) and by the absence of mesal extensions on the copulatory ducts (Fig. 8d).

Description.-Male (holotype): Coloration: Carapace yellow with central white spot. Chelicerae brown. Condyles light brown. Endites and labium light brown with white tips. Sternum dark brown with a central yellow foliage-shaped band. Legs yellow, patella-tibia with borders dark brown. Opisthosoma light brown with anterior dark brown spot, yellow foliage, and lateral dark brown spots. Spinnerets yellow, basal segment of PLS with black borders.

Habitus: Total length 7.75. Carapace length 4.25, width 2.88 , cephalic region width 1.43 , ocular region width 0.76 . Eye diameter: AME 0.13, ALE, PME and PLE 0.15. Distance 


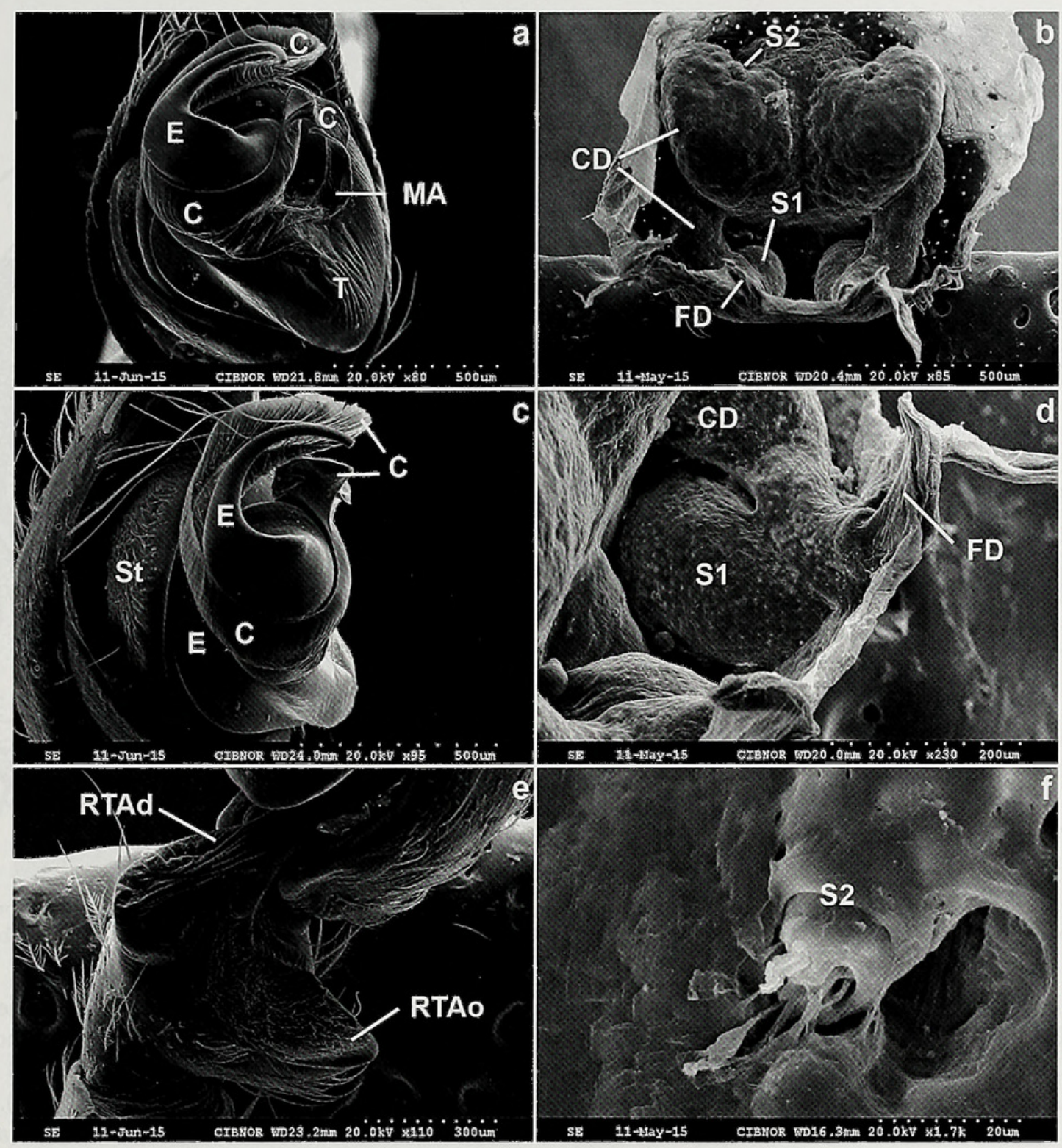

Figure 9.-Bajacalilena clarki sp. nov., genitalia (SEM). a, c, e. Male pedipalp. b, d, f. Epigynum. Abbreviations: C, conductor; CD, copulatory ducts; E, embolus; FD, fertilization ducts; MA, median apophysis; RTAd, distal projection of RTA; RTAo, dorsal projection of RTA; S1, primary spermathecae; S2, secondary spermathecae; St, subtegulum; T, tegulum.

between eyes: AME-AME 0.04, AME-ALE 0.04, AME-PME 0.19, ALE-PLE 0.06, ALE-ALE 0.35, PME-PME 0.08, PMEPLE 0.06. Clypeus height 0.31. Chelicerae: basal segment length 1.67 , fang length 0.71 . Labium wider than long $(0.62 /$ 0.52 ). Endites slightly convergent (distance at their base compared to their tips $0.68 / 0.38)$. Sternum longer than wide (1.95/1.52). Opisthosoma longer than wide (4/2.25). ALS separated by less than their basal diameter $(0.3 / 0.36)$, PLS with distal segment as long as basal segment $(0.61 / 0.61)$.

Legs: Length: I- femur 3.38/ patella-tibia $4.63 /$ metatarsus $3.88 /$ tarsus 2.38; II- 3.5/4.38/4/ 2.25; III- 3.38/4.38/4.63/ 2.38; IV- 4.75/ $5.63 / 6.38 / 2.88$.

Spination: Femur dorsal I- 1-2-2/ II- 1-3-2/ III- 1-3-3/ IV- 12-3; patella I- dorsal 1-1/ prolateral $1 /$ retrolateral 0; II- 1-1/ 1/ 0; III- $1-1 / 1 / 1$; IV- 1-1/ 1/ 1; tibia I- dorsal 1-1-0/ ventral 2-2$2 /$ prolateral 1-1-0/ retrolateral 0 ; II- 1-1-0/ 1-2-2/ 1-1-0/ 0; III$1-1-0 / 1-1-2 / 1-1-0 / 1-1-0 ;$ IV- $1-1-0 / 1-2-2 / 1-1-0 / 1-1-0$; metatarsus I- 0/ 2-2-2/ 0-1-1/ 0; II- 0/ 2-2-2/ 0-1-1/ 0-1-1; III- 3-
1-2/ 2-2-2/ 0-1-1/ 0-1-1; IV- 3-1-2/ 1-1-1-2-2/ 0-1-1/ 0-1-1. Number of trichobothria on tarsus: I- 5, II- 5, III- 5, IV- 6.

Pedipalp: Number of dorsal spines: femur 2, tibia 4. Cymbium length 1.7, width 1. Embolus with one and a half coils. Horseshoe-shaped membranous conductor. RTA with distal and dorsal projections and without excavations (Figs. 9a, c, e, 10).

Female (paratype) (AMNH): Coloration: Carapace brown, black spot between AME. Chelicerae reddish and condyles yellow. Endites and labium orange with white tips. Sternum orange with three pairs of black spots. Legs with three rings on femur and two on tibia. Coxa IV with diffuse spot on proximal part. Opisthosoma with an anterior red spot with a pair of lateral white spots that form a foliage and four pairs of black spots. Diffuse black spots laterally and ventrally. Spinnerets yellow.

Habitus: Total length 9. Carapace length 3.88, width 2.63, cephalic region width 1.19 , ocular region width 0.71 . Eye 


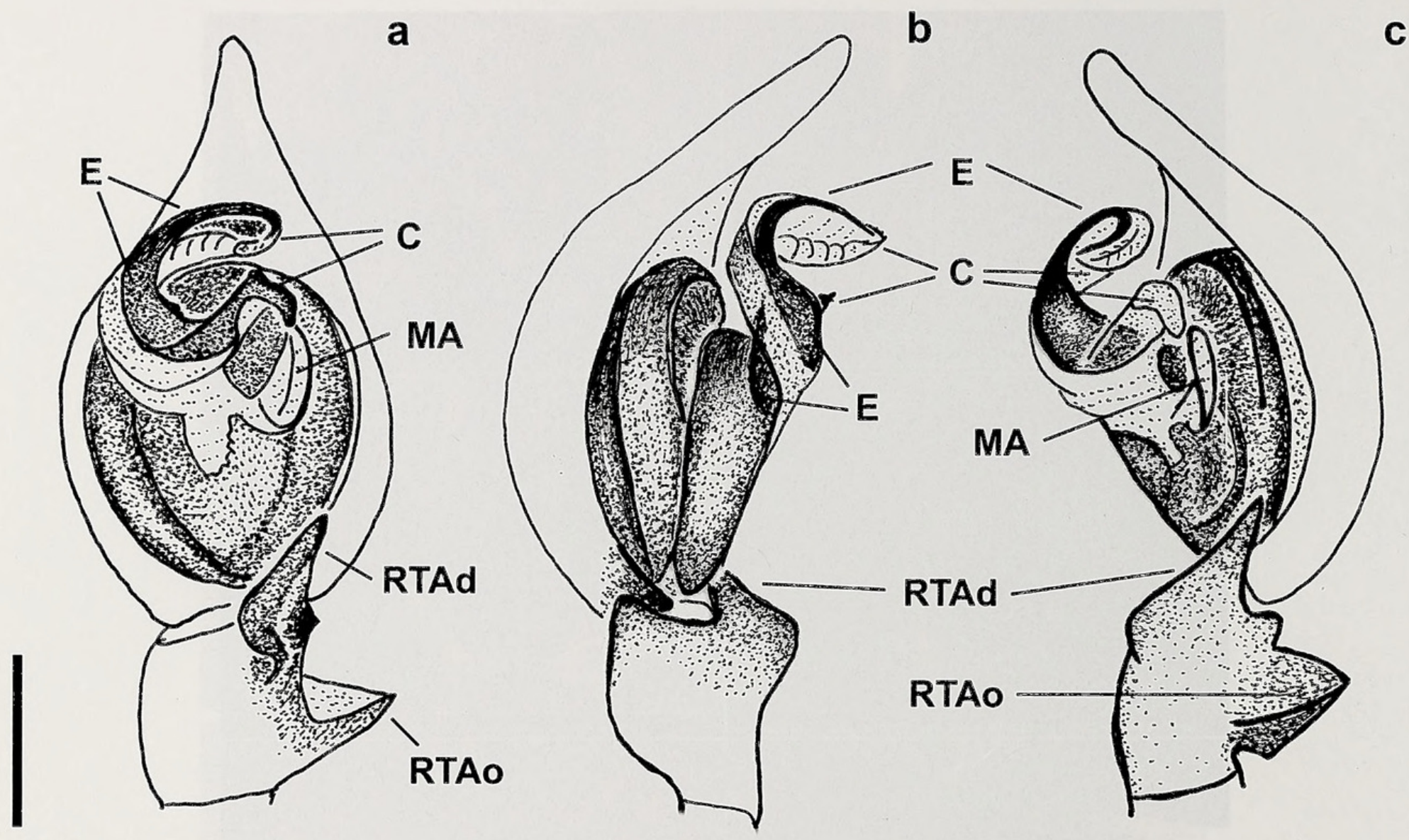

Figure 10.-Bajacalilena clarki sp. nov., male pedipalp. a. Ventral view. b. Prolateral view. c. Retrolateral view. Abbreviations: C, conductor; E, embolus; MA, median apophysis; RTAd, distal projection of RTA; RTAo, dorsal projection of RTA; T, tegulum. Scale bar $=0.5$ mm.

diameter: AME 0.15, ALE 0.17, PME and PLE 0.13. Distance between eyes: AME-AME 0.06, AME-ALE 0.04, AME-PME 0.15, ALE-PLE 0.04, ALE-ALE 0.35, PME-PME 0.1, PMEPLE 0.1. Clypeus height 0.25. Chelicerae: basal segment length 1.43, fang length 0.67 . Labium wider than long $(0.61 / 0.45)$. Endites slightly convergent (distance at their base compared to their tips $0.61 / 0.39)$. Sternum longer than wide (1.81/1.52). Opisthosoma longer than wide (5/3.25). ALS separated by less than their basal diameter $(0.27 / 0.33)$, PLS with distal segment as long as basal segment $(0.61 / 0.61)$.

Legs: Length: I- femur 2.88/ patella-tibia 3.38/ metatarsus $2.5 /$ tarsus 1.75 ; II- $2.88 / 3.38 / 2.5 / 1.5$; III- $2.88 / 2.38 / 2.75 /$ 1.63; IV- 3.13/4.38/4.38/ 2.

Spination: Femur dorsal I- 1-2-3/ II- 1-3-3/ III- 1-3-3/ IV- 12-2; patella I- dorsal 1-1/ prolateral 1 / retrolateral 0 ; II- 1-1/ 1 / 0 ; III- 1-1/ 1/ 1; IV- 1-1/ 1/ 1; tibia I- dorsal 1-1-0/ ventral 2-22/ prolateral 1-1-0/ retrolateral 0; II- 1-1-0/ 1-2-2/ 1-1-0/ 0; III$1-1-0 / 1-1-2 /$ 1-1-0/ 1-1-0; IV- 1-1-0/ 1-2-2/ 1-1-0/ 1-1-0; metatarsus I- $0 / 2-2-2 / 0-1-1 / 0-0-1$; II- $0 / 1-2-2 / 0-1-1 / 0-0-1$; III- 3-1-2/ 2-2-2/ 0-1-1/ 0-1-1; IV- 3-1-2/ 1-1-1-2-2/ 0-1-1/0-11. Number of trichobothria on tarsus: I- 5 , II- 5 , III- 5 , IV- 5 . Pedipalp: Dorsal spines on femur: 2. Prolateral spines on tibia: 1-2.

Epigynum: Plate length 0.76 , width 1.1. Copulatory ducts with anterior part separated by three times their width. Primary spermathecae separated by less than their width (Figs. $8 b, d, f, 9 b, d, f)$.
Variation.- Total body length in males varies between 5.75 and $10(n=14)$ and in females between 7.5 and $10.38(n=7)$. Carapace length in males varies between 2.88 and $5(n=15)$ and in females between 2.75 and $4.63(n=7)$. Patella-tibia I length in males varies between 3 and $5.25(n=15)$ and in females between 3 and $4.25(n=7)$.

Distribution.-Baja California and Baja California Sur (Mexico) (Fig. 23a).

\section{Cabolena Maya-Morales \& Jiménez gen. nov. http://zoobank.org/?lsid=urn:lsid:zoobank. org:act:4E727171-8324-4492-9B62-C33F30C89392}

Type species.-Cabolena kosatli sp. nov.

Etymology.-The generic name is derived from Los Cabos, the region where the genus is distributed. The gender is feminine.

Diagnosis.-Cabolena gen. nov. is diagnosed by the following characters in combination: epigynum with the median field of plate wider posteriorly and clearly differentiated from lateral lobes by epigynal folds or sutures (Figs. 12c, $14 \mathrm{c}, 16 \mathrm{c})$; copulatory openings at central position of plate length (Figs. 12c, 16c); copulatory ducts at ventral (Fig. 13d) or mesal (Fig. 11d) position in relation to primary spermathecae; primary spermathecae longer than wide (Figs. 11b, 13b); and secondary spermathecae in diverticula (Fig. 14d). Male pedipalp with simple curved embolus originating at median part of bulb length (Fig. 13a); conductor with two 

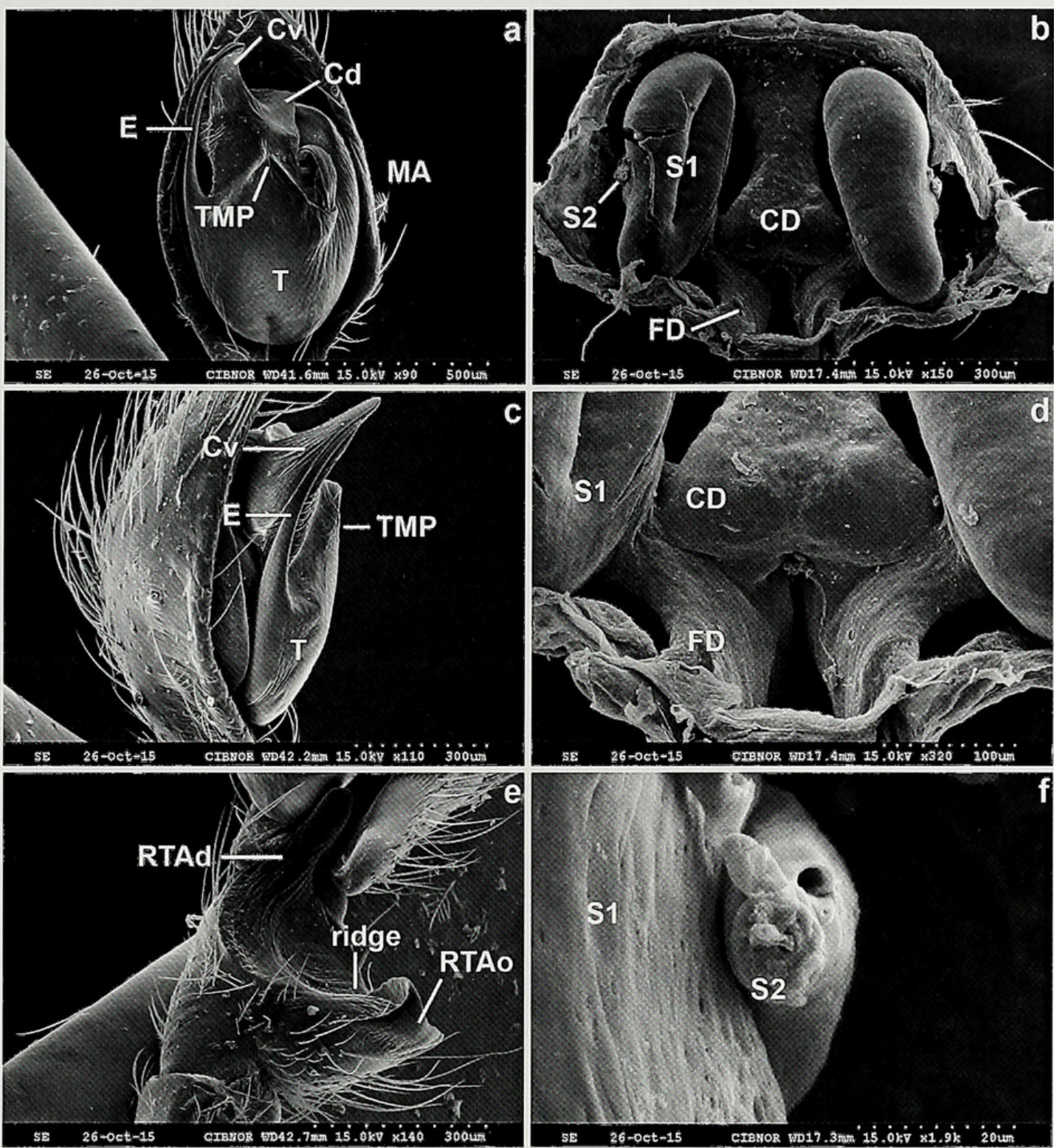

Figure 11.-Cabolena huiztocatl sp. nov., genitalia (SEM). a, c, e. Male pedipalp. b, d, f. Epigynum. Abbreviations: CD, copulatory ducts; Cd, dorsal projection of conductor; Cv, ventral projection of conductor; E, embolus; FD, fertilization ducts; MA, median apophysis; RTAd, distal projection of RTA; RTAo, dorsal projection of RTA; S1, primary spermathecae; S2, secondary spermathecae; T, tegulum; TMP, tegular median process.

projections (Fig. 11a, 15a); and RTA with a ridge on the dorsal projection (Figs. 11e, 15e).

Cabolena gen. nov. differs from Eratigena and Tegenaria by having strongly procurved eye rows in frontal view; from Agelenopsis, Barronopsis, Melpomene and Tortolena by having the embolus slightly curved and by the absence of a tegular lateral process; from Calilena by the absence of both a membranous fulcrum on the male pedipalp and a scape on the epigynum; from Hololena by having the embolus supported by the conductor only and having the primary spermathecae longer than wide; from Rualena by the absence of both a fulcrum and a posterior ridge on the epigynal plate (as in Maya-Morales 2016: fig. 30); from Rothilena by having the conductor with two projections and by the absence of hoods on the atrium; from Bajacalilena gen. nov. by having the embolus slightly curved and by the shape of the epigynal plate, which has the median field clearly differentiated from the lateral lobes; and from Callidalena gen. nov. by having the conductor with two projections and the primary spermathecae not folded. Cabolena gen. nov. also differs from Bajacalilena gen. nov., Callidalena gen. nov., Calilena, Hololena, Rualena, and Rothilena by having three to four retromarginal teeth on the chelicerae. Cabolena gen. nov. differs from Lagunella gen. nov. by having the embolus short and slightly curved and by the shape of the epigynal plate, which has the median field clearly differentiated from the lateral lobes; from Novalena by having a ridge on the dorsal projection of the RTA and copulatory openings separated by less than their width; and from Hoffmannilena by having a dorsal projection on the RTA and by the absence of a strongly sclerotized epigynal plate.

Description.-Medium-sized spiders, 4-13 $\mathrm{mm}$ total length. Both eye rows strongly procurved in frontal view. Feathery scale-like setae present on carapace, opisthosoma, pedipalps, and legs. Carapace with two longitudinal symmetrical dark 

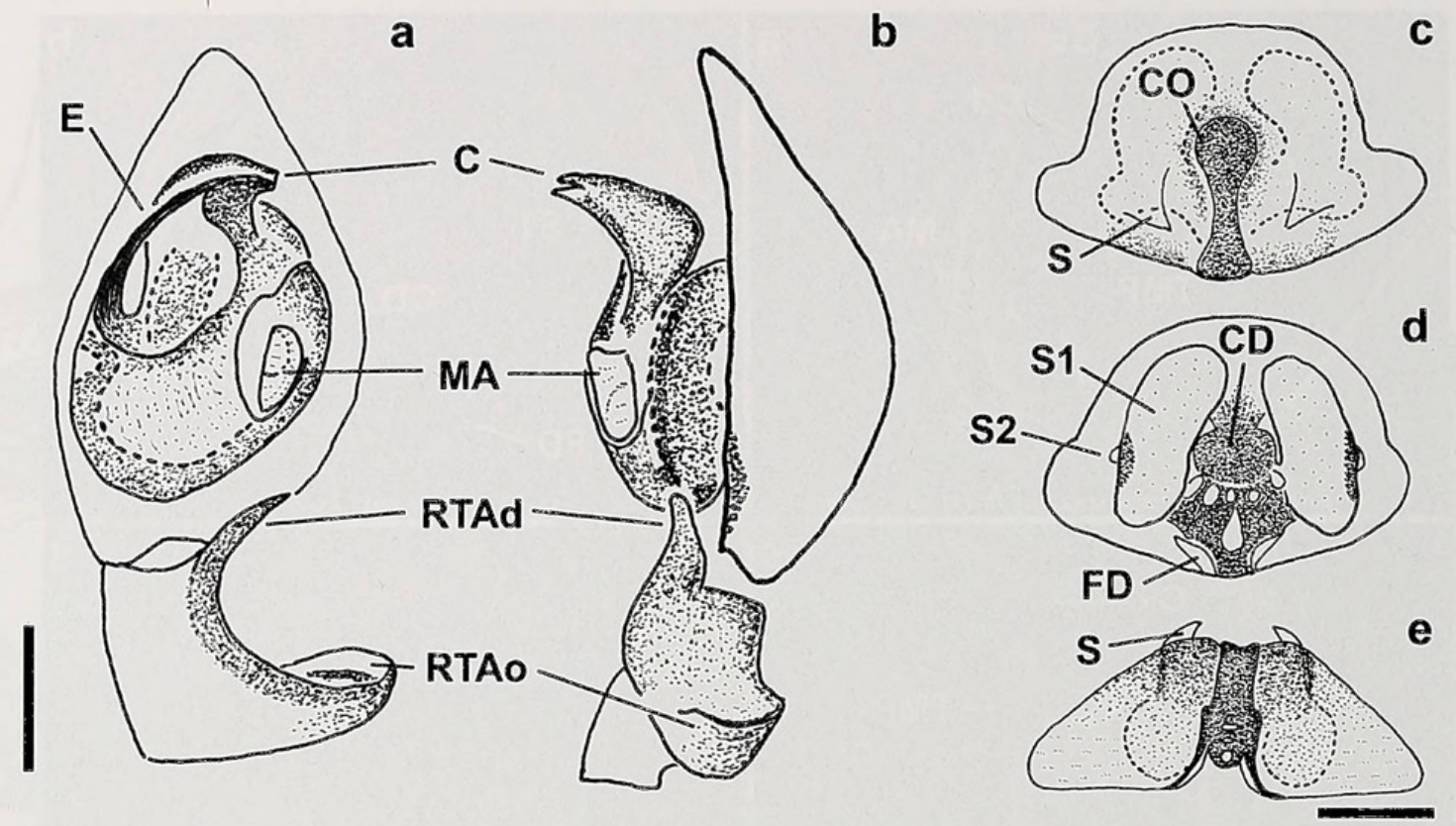

Figure 12.-Cabolena huiztocatl sp. nov., genitalia. a, b. Male pedipalp. c-e. Epigynum. a, c. Ventral view. b. Retrolateral view. d. Dorsal view. e. Posterior view. Abbreviations: $\mathrm{C}$, conductor; $\mathrm{CD}$, copulatory ducts; $\mathrm{CO}$, copulatory openings; $\mathrm{E}$, embolus; $\mathrm{FD}$, fertilization ducts; $\mathrm{MA}$, median apophysis; RTAd, distal projection of RTA; RTAo, dorsal projection of RTA; S, spurs; S1, primary spermathecae; S2, secondary spermathecae. Scale bars $=0.25 \mathrm{~mm}$.

bands intensified by feathery setae, a black band around the border of thoracic region, and a clear median band wider on cephalic region. Chelicerae with three promarginal teeth and three to four retromarginal teeth. Sternum longer than wide. Pedipalp femur with three dorsal spines. Legs with spines, longer in males than in females. Leg IV the longest. Rings present on femur, patella and tibia. Patella-tibia I longer than carapace in males and usually longer than carapace in females. Patella I and II with two dorsal spines and one prolateral spine, patella III and VI with two dorsal spines, one prolateral spine, and one retrolateral spine. Leg tarsi with five to seven trichobothria. Capsulate tarsal organ in distal position of trichobothrial row. Opisthosoma oval with dorsal foliate pattern and/or posterior chevrons. Colulus divided, represented by few hairs. PLS longest with distal segment usually as long as basal. Male pedipalp with short embolus originating at medium part of tibia length (Fig. 16a). Conductor with two projections (Fig. 11a). Median apophysis an elongated, spoonshaped membrane (Fig. 14a). RTA covering the entire tibia length with distal and dorsal projections and a ridge (Fig. 15e). Tibia with prolaterodorsal protuberance. Epigynal plate wider than long (Fig. 12c) with median field of plate wider posteriorly and clearly differentiated from lateral lobes by epigynal folds or sutures (Fig. 16c). Anterolateral hyaline spurs present (Fig. 14c). Copulatory openings in central position of plate length (Fig. 14c). Copulatory ducts in ventral (Fig. 13d) or mesal (Fig. 11b) position in relation to primary spermathecae. Primary spermathecae longer than wide (Fig. 16d). Secondary spermathecae in diverticula (Fig. 15d). Fertilization ducts short (Fig. 13b).

Distribution.-Cabolena gen. nov. is distributed in Mexico in the State of Baja California Sur (Fig. 23b).

Included taxa.-Three species: C. huiztocatl sp. nov., $C$. kosatli sp. nov. and C. sotol sp. nov.
Cabolena huiztocatl Maya-Morales \& Jiménez sp. nov. http://zoobank.org/?lsid=urn:lsid:zoobank. org:act:64F8B9F5-F8F0-4D46-93FB-88E84CDA1B89

(Figs. 1a, c, e, 11, 12, 23b)

Type material.-Holotype female: Municipality of La Paz, Biosphere Reserve Sierra La Laguna, La Cieneguita, Baja

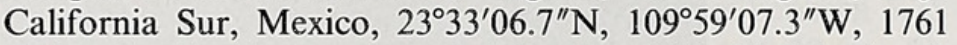
$\mathrm{m}$, hand collecting on ground, 4 October 2011, C. Palacios, J. Maya \& J. Villarreal (CARCIB 1876). Paratypes: MEXICO: Baja California Sur: 1 \%, same data as holotype except Las Cascadas, $23^{\circ} 32^{\prime} 58^{\prime \prime} \mathrm{N}, 109^{\circ} 58^{\prime} 55^{\prime \prime} \mathrm{W}, 1748 \mathrm{~m}, 3$ November 2006, M. Correa (CARCIB 2523); 1 đ, same data as holotype except road to La Palma, $23^{\circ} 33^{\prime} 22.6^{\prime \prime} \mathrm{N}, 109^{\circ} 58^{\prime} 43.5^{\prime \prime} \mathrm{W}, 1818$ $\mathrm{m}$, beat sheet, 5 October 2011 (CARCIB 1886); 3 ㅇ, Municipality of La Paz, Punta San Pedro, $23^{\circ} 23^{\prime} 22.4^{\prime \prime} \mathrm{N}$, $110^{\circ} 12^{\prime} 30.2^{\prime \prime} \mathrm{W}, 6 \mathrm{~m}$, hand collecting, 7 February 2013, M.L. Jiménez, C. Palacios \& J. Maya (CARCIB 32); 1 , same data (CARCIB 3345); 2 \%, same data (CARCIB 3611); 2 o, same data (CARCIB 3612); 1 , same data except 18 January 2013 (CARCIB 3613); 1 , same data except beat sheet, 28 August 2005, M. Correa (CARCIB 1893); 1 ô, same data except 7 August 2005, C. Palacios (CARCIB 1903); 1 , same data except 31 August 2005 (CARCIB 1895); 1 , same data except 3 August 2005 (CARCIB 1899).

Other material examined.-MEXICO: Baja California Sur:

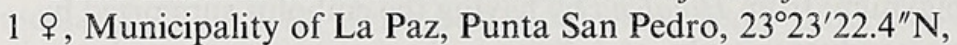
$110^{\circ} 12^{\prime} 30.2^{\prime \prime} \mathrm{W}, 6 \mathrm{~m}$, hand collecting, 7 February 2013, M.L. Jiménez, C. Palacios \& J. Maya (CARCIB 41); 2 \%, same data (CARCIB 44); 1 , same data (CARCIB 3344); 1 , same data (CARCIB 3420); 1 , same data except beat sheet, 31 August 2005, C. Palacios (CARCIB 1894); 1 \&, Biosphere Reserve Sierra La Laguna, Cerro Madroñito, $23^{\circ} 32^{\prime} 58^{\prime \prime} \mathrm{N}$, $109^{\circ} 58^{\prime} 55^{\prime \prime} \mathrm{W}$, beat sheet, 3 November 2006, C. Palacios (CARCIB 2522). 


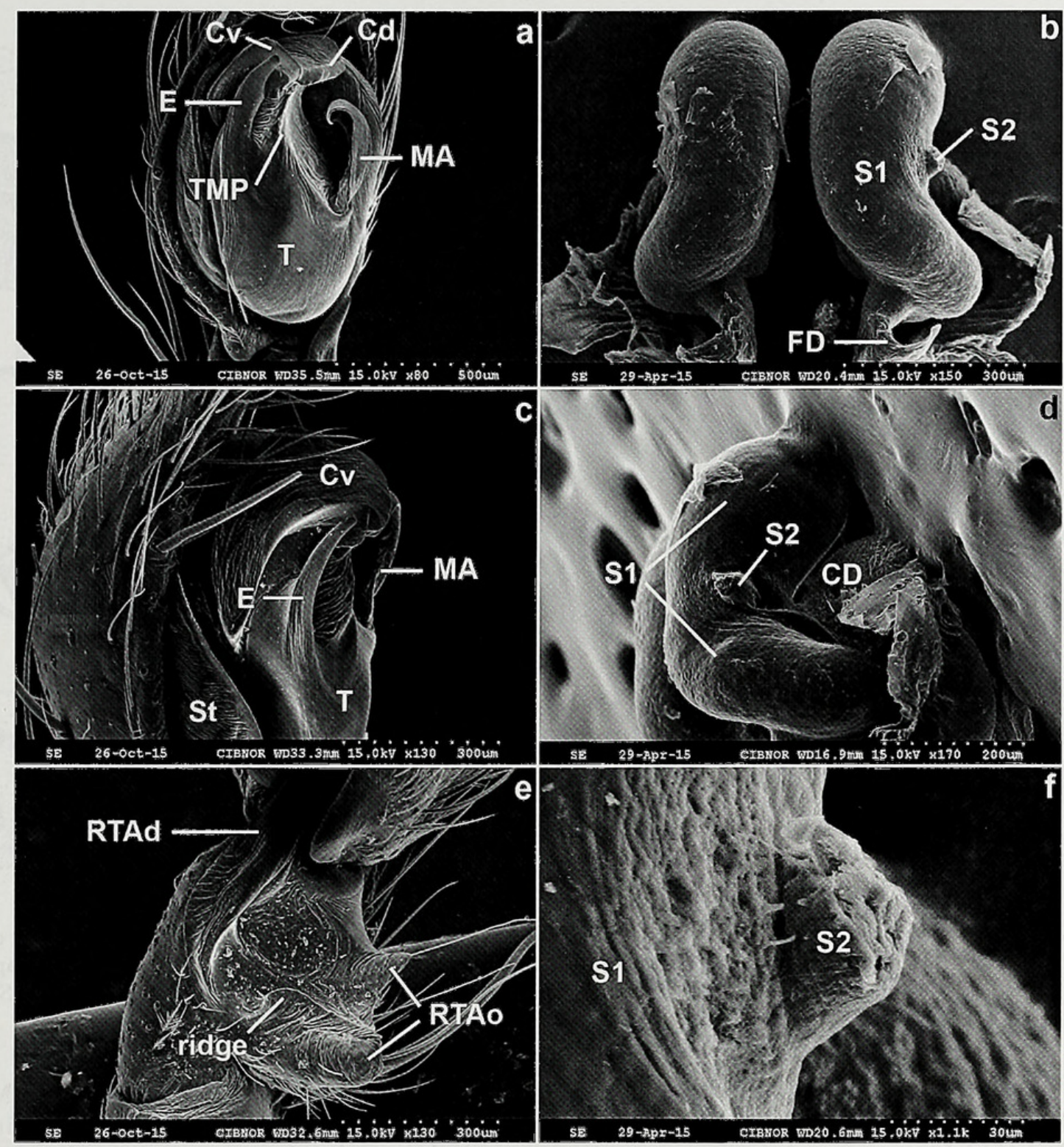

Figure 13.-Cabolena kosatli sp. nov., genitalia (SEM). a, c, e. Male pedipalp. b, d, f. Epigynum. Abbreviations: CD, copulatory ducts; Cd, dorsal projection of conductor; Cv, ventral projection of conductor; E, embolus; FD, fertilization ducts; MA, median apophysis; RTAd, distal projection of RTA; RTAo, dorsal projection of RTA; S1, primary spermathecae; S2, secondary spermathecae; St, subtegulum; T, tegulum; TMP, tegular median process.

Etymology.-The specific name is the Náhuatl word "huiztocatl" which means "spider with spines".

Diagnosis.-Females of this species differ from C. kosatii and $C$. sotol by having the median plate of the epigynum strongly sclerotized (Fig. 12c) and by the copulatory ducts, which are clearly visible in dorsal view (Fig. 12d). Males differ from $C$. kosatli by having a conductor with the ventral projection longer than the dorsal one (Fig. 12a); and from $C$. sotol by having one spermophore coil visible through the tegulum (Fig. 12a).

Description.-Female (holotype): Coloration: Carapace yellow. Chelicerae and condyles brown. Endites yellow with white tips. Labium greyish with white tips. Sternum greyish with a yellow central band and three pairs of lateral spots. Legs yellow, patella-metatarsus brown. Three black rings on femur, one on patella, and two on tibia. Opisthosoma black, anterior reddish spot, six pairs of lateral yellow spots. ALS yellow with black border, PLS black, distal segment reddish.

Habitus: Total length 7. Carapace length 3.38 , width 2.13, cephalic region width 1.15 , ocular region width 0.7 . Eye diameter: AME 0.12, ALE 0.17, PME and PLE 0.15. Distance between eyes: AME-AME 0.06, AME-ALE 0.06, AME-PME 0.13, ALE-PLE 0.06, ALE-ALE 0.29, PME-PME 0.1, PMEPLE 0.08. Clypeus height 0.17 . Chelicerae with three retromarginal teeth; basal segment length 1.12, fang length 0.52 . Labium wider than long $(0.48 / 0.39)$. Endites convergent (distance at their base compared to their tips 0.48/0.21). Sternum longer than wide (1.48/1.19). Opisthosoma longer than wide $(3.5 / 2.13)$. ALS separated by less than their basal diameter $(0.12 / 0.3)$, PLS with distal segment as long as basal segment $(0.36 / 0.36)$. 

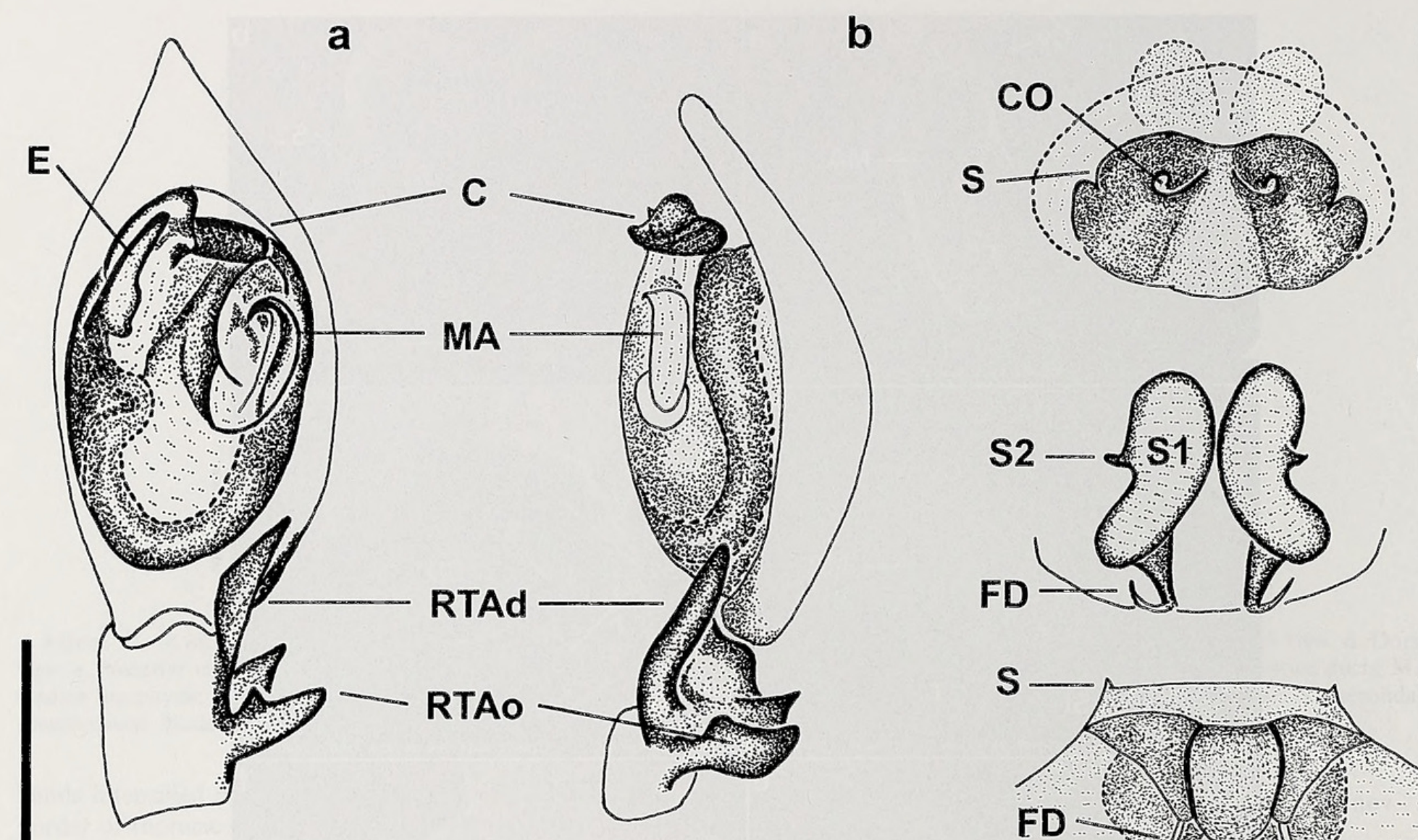

C

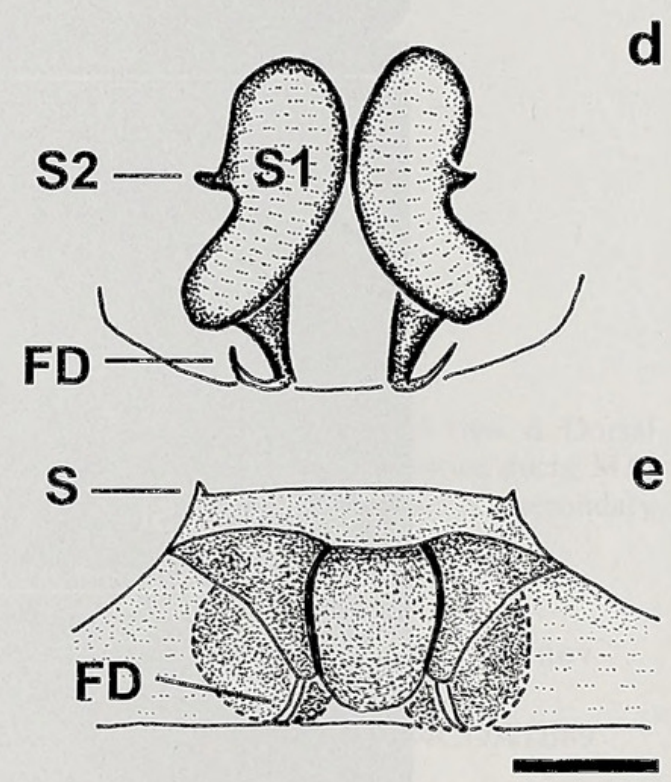

Figure 14.-Cabolena kosatli sp. nov., genitalia. a, b. Male pedipalp. c-e. Epigynum. a, c. Ventral view. b. Retrolateral view. d. Dorsal view. e. Posterior view. Abbreviations: C, conductor; CO, copulatory openings; E, embolus; FD, fertilization ducts; MA, median apophysis; RTAd, distal projection of RTA; RTAo, dorsal projection of RTA; S, spurs; S1, primary spermathecae; S2, secondary spermathecae. Scale bars: a $=0.5$ $\mathrm{mm} ; \mathrm{e}=0.25 \mathrm{~mm}$.

Legs: Length: I- femur 2.46/ patella-tibia 3.23/ metatarsus 2.31 / tarsus 1.46 ; II- $2.31 / 2.92 / 2.15 / 1.15$; III- $2.3 / 2.92 / 2.46 /$ 1.15 ; IV- 3.08/3.77/3.46/1.69.

Spination: Femur dorsal I- 1-2-3/ II- 1-3-3/ III- 1-3-3/ IV-12-3; patella I- dorsal 1-1/ prolateral 1 / retrolateral 0; II- 1-1/ 1 / 0 ; III- 1-1/ 1/ 1; IV- 1-1/ 1/ 1; tibia I- dorsal 1-1-0/ ventral 2-2$2 /$ prolateral $1-1-0 /$ retrolateral 0 ; II- $1-1-0 / 1-2-2 / 1-1-0 / 0$; III$1-1-0 / 1-2-2 /$ 1-1-0/ 1-1-0; IV- 1-1-0/ 1-2-2/ 1-1-0/ 1-1-0; metatarsus I- 0/ 2-2-2/ 0-1-1/ 0; II- 0-0-1/ 2-2-2/ 0-1-1/ 0-1-0; III- 3-1-2/ 1-2-2/ 0-1-1/ 0-1-1; IV- 3-1-2/ 1-1-1-2-2/0-1-1/ 0-11. Number of trichobothria on tarsus: I- 5, II- 6, III- 5, IV- 5 .

Pedipalp: Dorsal spines on femur: 3. Prolateral spines on tibia: $1-2$.

Epigynum: Plate length 0.67 , width 0.85 . Median plate strongly sclerotized. In posterior view, median plate uniformly wide. Copulatory ducts visible in dorsal view. Primary spermathecae uniformly wide and separated by their width (Figs. 11b, d, f, 12c-e).

Male (CARCIB 1903): Coloration: Similar to female, opisthosoma light brown with anterior brown spots and lateral white spots (Fig. 1c).

Habitus: Total length 5. Carapace length 2.38, width 1.88 , cephalic region width 0.91 , ocular region width 0.55 . Eye diameter: AME and PME 0.1, ALE 0.12, PLE 0.13. Distance between eyes: AME-AME 0.04, AME-ALE 0.04, AME-PME
0.12, ALE-PLE 0.06, ALE-ALE 0.23, PME-PME 0.06, PMEPLE 0.1. Clypeus height 0.1. Chelicerae with three retromarginal teeth; basal segment length 0.91, fang length 0.39 . Labium wider than long $(0.36 / 0.27)$. Endites strongly convergent (distance at their base compared to their tips $0.36 / 0.06$ ). Sternum longer than wide (1.52/1.1). Opisthosoma longer than wide $(2.5 / 1.75)$. ALS separated by their basal diameter $(0.21 /$ $0.21)$, PLS with distal segment as long as basal segment $(0.3 /$ $0.3)$.

Legs: Length: I- femur 2.25/ patella-tibia $2.75 /$ metatarsus 1.88 / tarsus 1.5; II- $2.25 / 2.5 / 1.88 / 1.38$; III- $1.88 / 2.25 / 2.25$ / 1.13 ; IV- $2.5 / 3.13 / 3 / 1.5$.

Spination: Femur dorsal I- 1-2-3/ II- 1-3-3/ III- 1-3-3/ IV- 12-3; patella I- dorsal $1-1 /$ prolateral $1 /$ retrolateral 0 ; II- 1-1/ 1 / 0 ; III- $1-1 / 1 / 1$; IV- $1-1 / 1 / 1$; tibia I- dorsal $0 /$ ventral 2-2-2/ prolateral 1-1-0/ retrolateral 0 ; II- 1-0-0/ 1-2-2/ 1-1-0/ 0 ; III- $1-$ 1-0/ 1-2-2/ 1-1-0/ 1-1-0; IV- 1-1-0/ 2-2-2/ 1-1-0/ 1-1-0; metatarsus I- $0 / 2-2-2 / 0-1-1 / 0-1-1$; II- 0/ 2-2-2/ 0-1-1/ 0-1-0; III- 2-1-2/ 2-2-2/ 0-1-1/ 0-1-1; IV- 3-1-2/ 1-1-1-2-2/ 0-1-1/ 0-11. Number of trichobothria on tarsus: I- 6 , II- 5 , III- 5 , IV- 6 .

Pedipalp: Number of dorsal spines: femur 3, tibia 3. Cymbium length 0.88 , width 0.55 . Embolus uniformly slender. Conductor with ventral projection larger than dorsal one. One coil visible through the tegulum on mesal margin. RTA with dorsal projection flattened (Figs. 11a, c, e, 12a, b). 

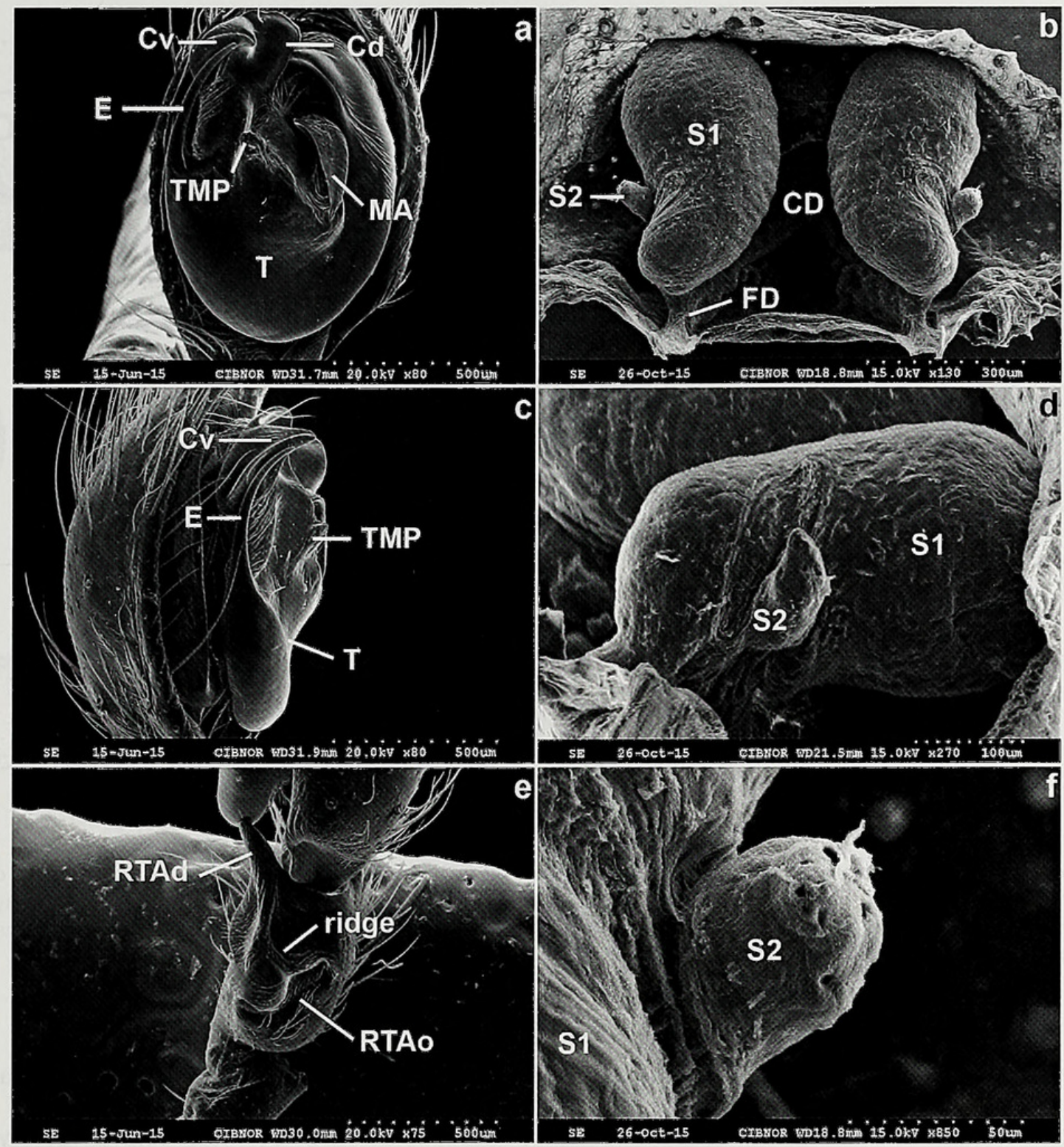

Figure 15.-Cabolena sotol sp. nov., genitalia (SEM). a, c, e. Male pedipalp. b, d, f. Epigynum. Abbreviations: CD, copulatory ducts; Cd, dorsal projection of conductor; $\mathrm{Cv}$, ventral projection of conductor; E, embolus; FD, fertilization ducts; MA, median apophysis; RTAd, distal projection of RTA; RTAo, dorsal projection of RTA; S1, primary spermathecae; S2, secondary spermathecae; T, tegulum; TMP, tegular median process.

Variation. - Total body length in males varies between 4.63 and $5.75(n=4)$ and in females between 4.88 and $7(n=12)$. Carapace length in males varies between 2.38 and $2.88(n=4)$ and in females between 2.5 and $3.38(n=12)$. Patella-tibia I length in males varies between 2.75 and $3.25(n=4)$ and in females between 2.38 and $3.25(n=12)$. One female paratype with four retromarignal teeth on chelicerae.

Natural history.-Seven adult females and two immature males from Punta San Pedro were kept under laboratory conditions for five months. Each female laid one to seven egg sacs. The males died two to three months after their last molt. As reported for Agelenopsis aperta (Gertsch, 1934) (Gering 1953; Becker et al. 2005), the male induces the female to a state of quiescence before they mate. In one mating observation, the male held the female with four legs on the same side of the pedipalp used to copulate (Fig. 1e). The pedipalp was constantly lubricated. The other pedipalp moved from top to bottom during lubrication. Fourteen minutes later, the pedipalp (and side) was changed. After 38 minutes of mating, the female recovered from the state of quiescence and the male and female separated quickly.

Habitat. - The specimens from Sierra La Laguna (1748$1818 \mathrm{~m}$ ) were found in the understory and on the ground of the pine-oak forest dominated by Pinus lagunae, Quercus tuberculata, Arbutus peninsularis, and Mimosa xanti (Wiggins 1980; Rebman \& Roberts 2012). The webs of spiders from the Punta San Pedro Oasis $(6 \mathrm{~m})$ were sighted from 0.5 to $4 \mathrm{~m}$ above the ground (Fig. 1a). The oasis is dominated by Washingtonia robusta and Phoenix dactylifera and is fed by a spring and separated from the sea by a broad beach and sand dunes (Llinas \& Jiménez 2004).

Distribution.-Baja California Sur (Mexico) (Fig. 23b). 


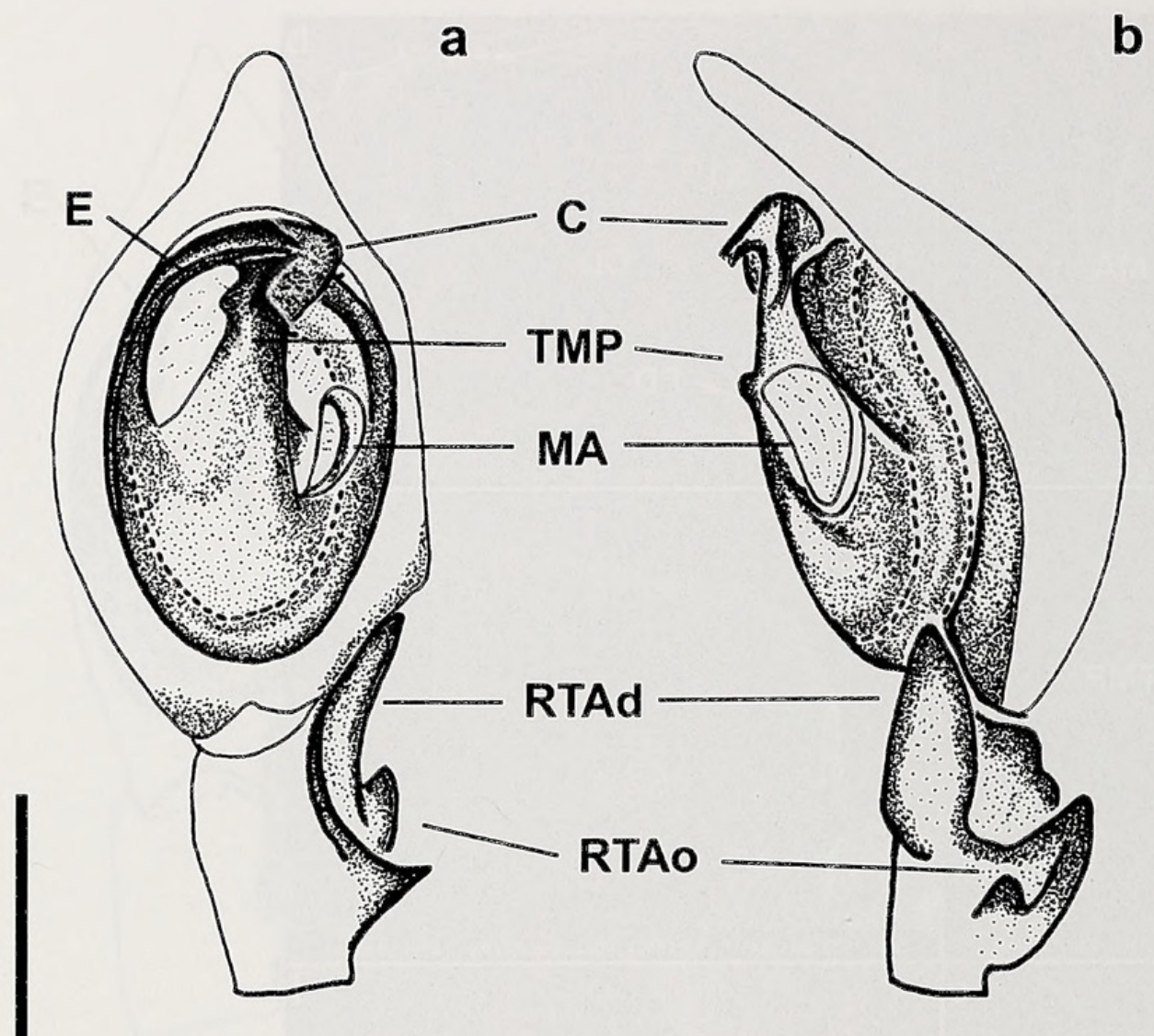

b

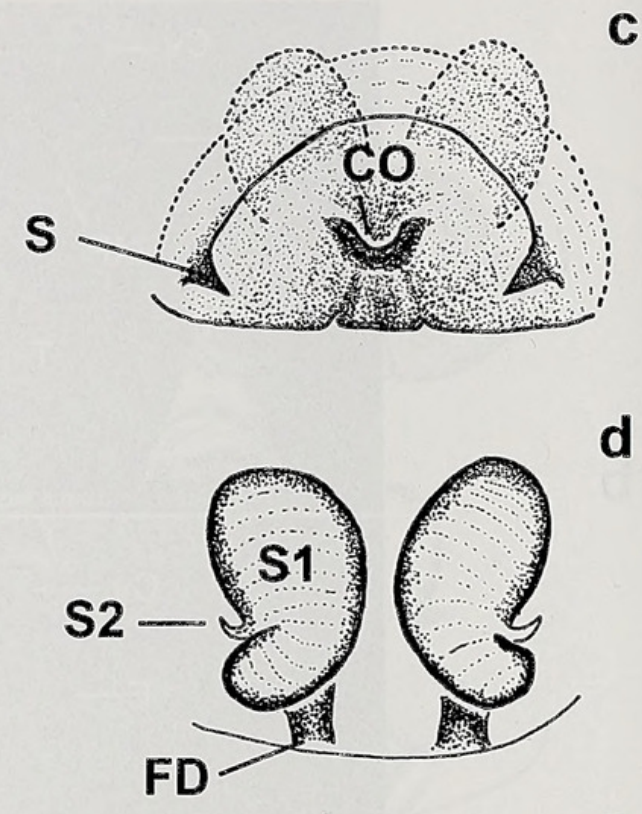

C

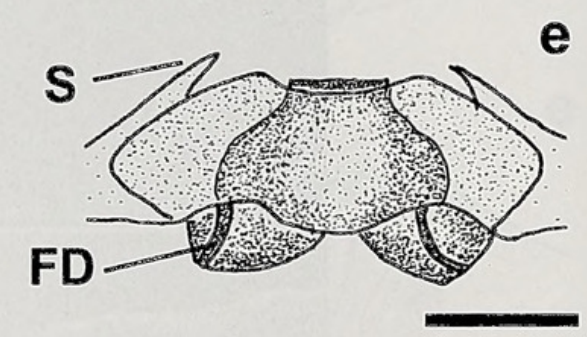

Figure 16.-Cabolena sotol sp. nov., genitalia. a, b. Male pedipalp. c-e. Epigynum. a, c. Ventral view. b. Retrolateral view. d. Dorsal view. e. Posterior view. Abbreviations: C, conductor; CO, copulatory openings; E, embolus; FD, fertilization ducts; MA, median apophysis; RTAd, distal projection of RTA; RTAo, dorsal projection of RTA; S, spurs; S1, primary spermathecae; S2, secondary spermathecae; TMP, tegular median process. Scale bars: $\mathrm{a}=0.5 \mathrm{~mm}$; $=0.35 \mathrm{~mm}$.

Cabolena kosatli Maya-Morales, Jiménez \& Palacios-Cardiel sp. nov.

http://zoobank.org/?lsid=urn:lsid:zoobank. org:act:217C9080-F457-4331-B393-2DC547BD3E33

(Figs. 13, 14, 23b)

Type material.-Holotype female: Municipality of La Paz, Biosphere Reserve Sierra La Laguna, road to Arroyo La

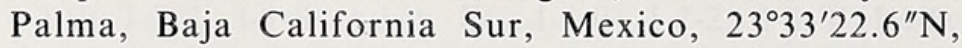
$109^{\circ} 58^{\prime} 43.5^{\prime \prime} \mathrm{W}, 1818 \mathrm{~m}$, hand collecting on ground, 5 October 2011, C. Palacios, J. Maya \& J. Villarreal (CARCIB 1877). Paratypes: MEXICO: Baja California Sur: 1 \%, same data as holotype except Cañón La Zorra, 1640 m, 3 July 1986, A. Cota (CARCIB 3); 1 o, 6 \%, same data except 4 March 1986, F. \& A. Cota (CARCIB 6); 1 o, 1 \%, same data as holotype except Valle La Laguna, 1630 m, 30 September 1987, M.L. Jiménez (CARCIB 13); 1 ठ์, same data except 19 April 1988 (CARCIB 17); 1 of, same data except 12 December 1986, F. Cota (CARCIB 3750); 1 ơ, same data except 25 February 1984 (CARCIB 3751); 1 \%, same data except March 1988 (CARCIB 3752); 1 \& , same data as holotype except La Cieneguita, $23^{\circ} 33^{\prime} 06.7^{\prime \prime} \mathrm{N}, 109^{\circ} 59^{\prime} 07.3^{\prime \prime} \mathrm{W}, 1761 \mathrm{~m}$, hand collecting on ground, 4 October 2011 (CARCIB 45); 1 के, same data (CARCIB 1878); 1 ठ, 1 \%, same data except $1640 \mathrm{~m}, 1$ November 1984, M.L. Jiménez (CARCIB 53); 2 đ, 1 \%, same data except 12 December 1986, A. Cota (CARCIB 1855); 1 으, same data as holotype except road to La Laguna, $23^{\circ} 33^{\prime} 06.8^{\prime \prime} \mathrm{N}$, $109^{\circ} 59^{\prime} 03.9^{\prime \prime} \mathrm{W}, 1757 \mathrm{~m}$, night collecting, 7 October 2011 (CARCIB 1874); 1 $\delta$, same data as holotype except Las Cascadas, $23^{\circ} 33^{\prime} 58^{\prime \prime} \mathrm{N}, 109^{\circ} 58^{\prime} 05^{\prime \prime} \mathrm{W}, 1748 \mathrm{~m}$, hand collecting on ground, 3 November 2006, M. Correa (CARCIB 2520);

Other material examined.-MEXICO: Baja California Sur: 4 , same data as holotype (CARCIB 46); 19 , same data as holotype (CARCIB 1896); 1 , same data as holotype except Cañón La Zorra, 1640 m, 28 September 1988, A. \& F. Cota (CARCIB 1); 1 \&, same data except M.L. Jiménez \& A. Cota (CARCIB 2); 1 o, 2 \%, same data except 13 January 1986, M.L. Jiménez (CARCIB 7); 1 \%, same data except 25 February 1987, M. Acevedo \& M.L. Jiménez (CARCIB 49); 1 ठ , same data except 19 August 1986, collectors unknown (CARCIB 1867); 4 \%, same data as holotype except Valle La Laguna, 20 April 1988, M.L. Jiménez \& S. Guzmán (CARCIB 8); 1 \&, same data except 20 April 1988, M.L. Jiménez (CARCIB 12); 12 \%, same data except $1630 \mathrm{~m}, 16$ January 1988, V. Roth \& M.L. Jiménez (CARCIB 14); 1 \%, same data (CARCIB 3343); 1 đ, same data except M.L. Jiménez (CARCIB 55); 2 \%, same data except 12 December 1986, A. Cota (CARCIB 1852); 1 \%, same data except 10 May 1985 (CARCIB 1853); 2 \&, same data as holotype except Cañón La Burrera, 11 December 1986, M. Acevedo (CARCIB 18); 1 , same data (CARCIB 20); 19 , same data as holotype except Palo Extraño, 21 April 1988, M.L. Jiménez \& D. Domínguez 


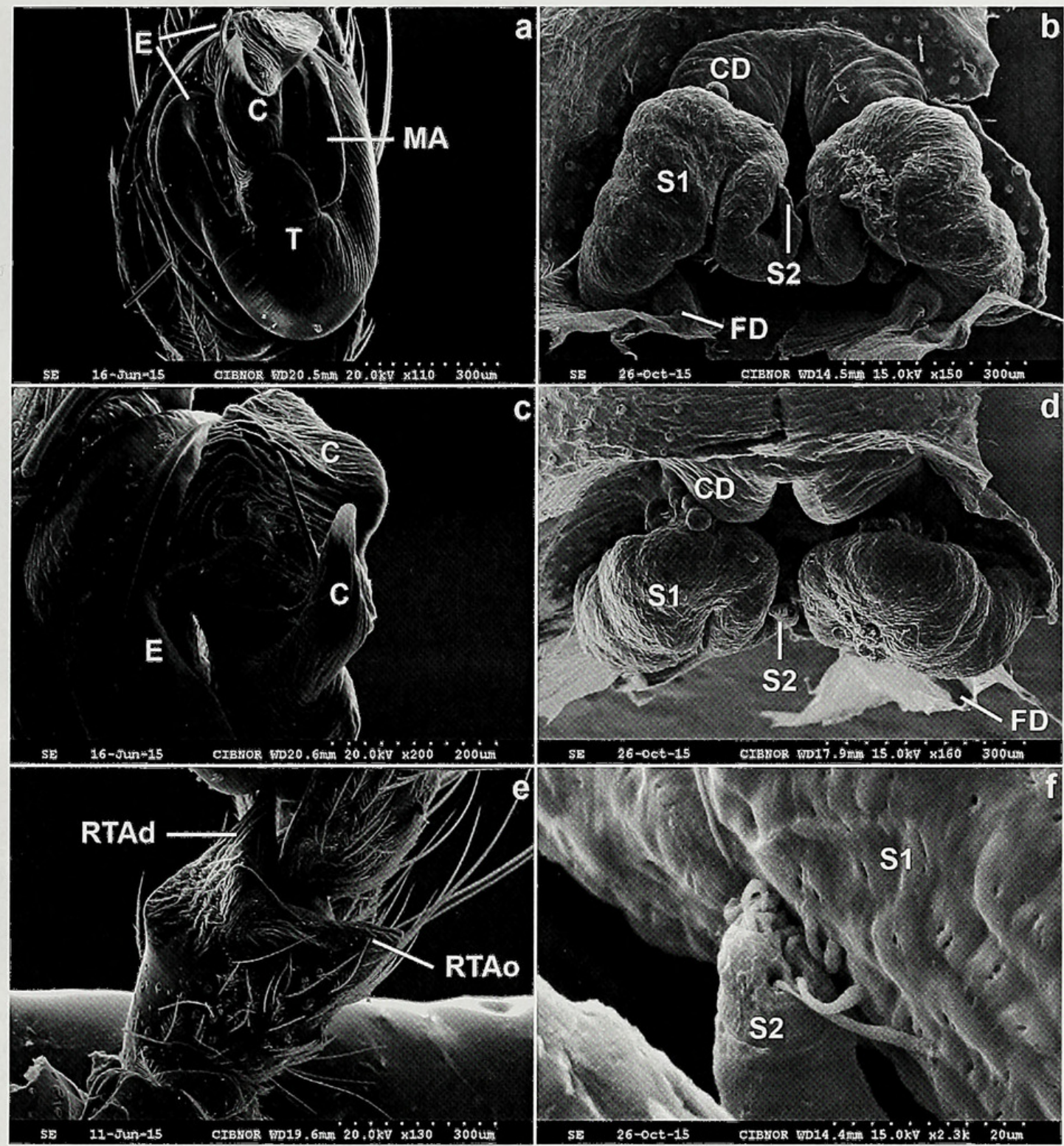

Figure 17.-Callidalena quintin sp. nov., genitalia (SEM). a, c, e. Male pedipalp. b, d, f. Epigynum. Abbreviations: CD, copulatory ducts; E, embolus; FD, fertilization ducts; MA, median apophysis; RTAd, distal projection of RTA; RTAo, dorsal projection of RTA; S1, primary spermathecae; S2, secondary spermathecae; T, tegulum.

(CARCIB 52); 4 \&, same data except 14 May 1986, F. Cota (CARCIB 11); 2 \%, same data as holotype except Las Cascadas, $23^{\circ} 32^{\prime} 56.9^{\prime \prime} \mathrm{N}, 109^{\circ} 58^{\prime} 07.6^{\prime \prime} \mathrm{W}, 1734 \mathrm{~m}, 8$ October 2011 (CARCIB 1879); 1 ㅇ, same data as holotype except Arroyo La Cieneguita, $23^{\circ} 33^{\prime} 02^{\prime \prime} \mathrm{N}, 109^{\circ} 56^{\prime} 26.8^{\prime \prime} \mathrm{W}, 1758 \mathrm{~m}, 7$ October 2011 (CARCIB 1888); 2 , same data except 19 April 1988, M.L. Jiménez (CARCIB 16); 1 \%, same data as holotype except Arroyo La Palma, 23⒊'24. $8^{\prime \prime} \mathrm{N}, 109^{\circ} 58^{\prime} 27^{\prime \prime} \mathrm{W}, 1798 \mathrm{~m}$, 6 October 2011 (CARCIB 1890).

Etymology.-The specific name is the Náhuatl word "kosatli" which means "vixen" ("zorra" in Spanish, the name of the canyon in the Sierra La Laguna where the species was found).

Diagnosis. - Females of $C$. kosatli differ from $C$. huiztocatl and $C$. sotol by having the copulatory openings easily distinguishable (Fig. 14c). Males differ from C. huiztocatl by having a conductor with the projections of similar size (Fig. 13a) and from $C$. sotol by having one spermophore coil visible through the tegulum (Fig. 14a).

Description.-Female (holotype): Coloration: Carapace yellow. Chelicerae brown. Condyles light brown. Endites orange with white tips. Labium light brown with white tip. Sternum yellow with black lateral lines. Femur yellow, patella-tarsus light brown. Three rings on femur, one on patella, and two on tibia. Opisthosoma brown, anterior reddish spot, two lateral white lines, four arrowhead shaped spots, several pairs of black spots, and one pair of white spots next to anal tubercle. Spinnerets yellow, basal segment of PLS with black spots.

Habitus: Total length 5.88. Carapace length 2.75, width 1.88 , cephalic region width 1.12 , ocular region width 0.61 . Eye diameter: AME 0.1, ALE, PME and PLE 0.13. Distance between eyes: AME-AME 0.04, AME-ALE 0.06, AME-PME 0.13, ALE-PLE 0.04, ALE-ALE 0.23, PME-PME 0.08, PMEPLE 0.06. Clypeus height 0.19 . Chelicerae with three retro- 

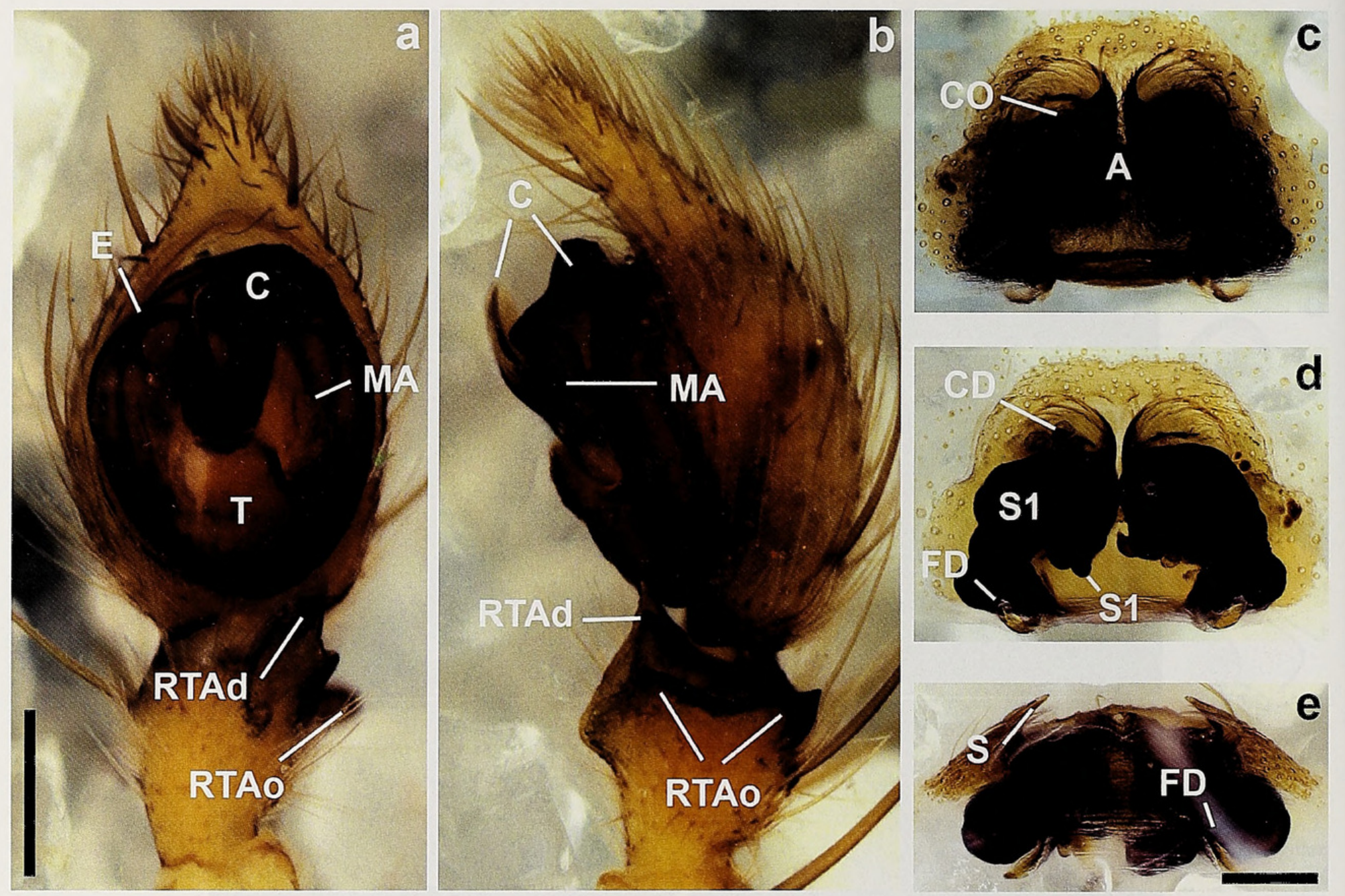

Figure 18.-Callidalena quintin sp. nov., genitalia. a, b. Male pedipalp. c-e. Epigynum. a, c. Ventral view; b. Retrolateral view. d. Dorsal view. e. Posterior view. Abbreviations: C, conductor; CO, copulatory openings; E, embolus; FD, fertilization ducts; MA, median apophysis; RTAd, distal projection of RTA; RTAo, dorsal projection of RTA; S, spurs; S1, primary spermathecae; S2, secondary spermathecae. Scale bars: a = 0.25 $\mathrm{mm} ; \mathrm{e}=0.2 \mathrm{~mm}$

marginal teeth; basal segment length 1.1 , fang length 0.45 . Labium wider than long $(0.45 / 0.36)$. Endites slightly convergent (distance at their base compared to their tips $0.45 / 0.3$ ). Sternum longer than wide $(1.45 / 1.18)$. Opisthosoma longer than wide $(3.13 / 2.25)$. ALS separated by less than their basal diameter $(0.21 / 0.27)$, PLS with distal segment slightly longer than basal segment $(0.52 / 0.48)$.

Legs: Length: I- femur 2.38/ patella-tibia 3.13/ metatarsus 2.13 / tarsus 1.5; II- $2.25 / 2.63 / 2 / 1.38$; III- 2.25/ $2.75 / 2.38$ / 1.25 ; IV- $2.88 / 3.75 / 3.13 / 1.63$.

Spination: Femur dorsal I- 1-2-3/ II- 1-3-3/ III- 1-3-3/ IV- 1$2-2$; patella I- dorsal $1-1 /$ prolateral $1 /$ retrolateral 0 ; II- $1-1 / 1$ / 0 ; III- $1-1 / 1 / 1$; IV- $1-1 / 1 / 1$; tibia I- dorsal $0 /$ ventral 2-2-2/ prolateral 1-1-0/ retrolateral 0; II- 1-0-0/ 1-2-2/ 1-1-0/ 0; III- 1$1-0 / 1-2-2 / 1-1-0 / 1-1-0$; IV- 1-1-0/ 1-1-1-2/ 1-1-0/ 1-1-0; metatarsus I- $0 / 2-2-2 / 0-1-1 / 0-0-1$; II- $0 / 2-2-2 / 0-1-0 / 0-1-1$; III- 2-1-2/ 2-2-2/ 0-1-1/ 0-1-1; IV- 3-1-2/ 2-1-2-2/ 0-1-1/ 0-1-1. Number of trichobothria on tarsus: I- 6, II- 5, III- 5, IV- 6.

Pedipalp: Dorsal spines on femur: 3. Prolateral spines on tibia: 1-2.

Epigynum: Plate length 0.61 , width 0.88 . In posterior view, median plate uniformly wide. Copulatory openings separated by less than their width. L-shaped primary spermathecae separated by less than their width (Figs. 13b, d, f, 14c-d).

Male (paratype) (CARCIB 6): Coloration: Yellow, opisthosoma with several light brown spots.

Habitus: Total length 6.88. Carapace length 3.38, width 2.5, cephalic region width 1.21 , ocular region width 0.67 . Eye diameter: AME, PME and PLE 0.12, ALE 0.13. Distance between eyes: AME-AME 0.04, AME-ALE 0.08, AME-PME 0.19, ALE-PLE 0.06, ALE-ALE 0.25, PME-PME 0.1, PMEPLE 0.1. Clypeus height 0.23 . Chelicerae with three retromarginal teeth; basal segment length 1.3, fang length 0.55 . Labium wider than long $(0.45 / 0.39)$. Endites slightly convergent (distance at their base compared to their tips $0.45 / 0.33$ ). Sternum longer than wide (1.67/1.42). Opisthosoma longer than wide $(3.5 / 1.88)$. ALS separated by less than their basal diameter $(0.21 / 0.27)$, PLS with distal segment as long as basal segment $(0.45 / 0.45)$.

Legs: Length: I- femur 3.13/ patella-tibia 3.75/ metatarsus $3.13 / \operatorname{tarsus} 2.13$; II- 3.13/3.63/3.63/ 1.75; III- 3.13/3.75/3.63/ 1.88; IV- 3.75/4.25/4.88/ 2.25

Spination: Femur dorsal I- 1-2-3/ II- 1-3-3/ III- 1-3-3/ IV- 12-3; patella I- dorsal 1-1/ prolateral 1/ retrolateral 0; II- 1-1/ 1 / 


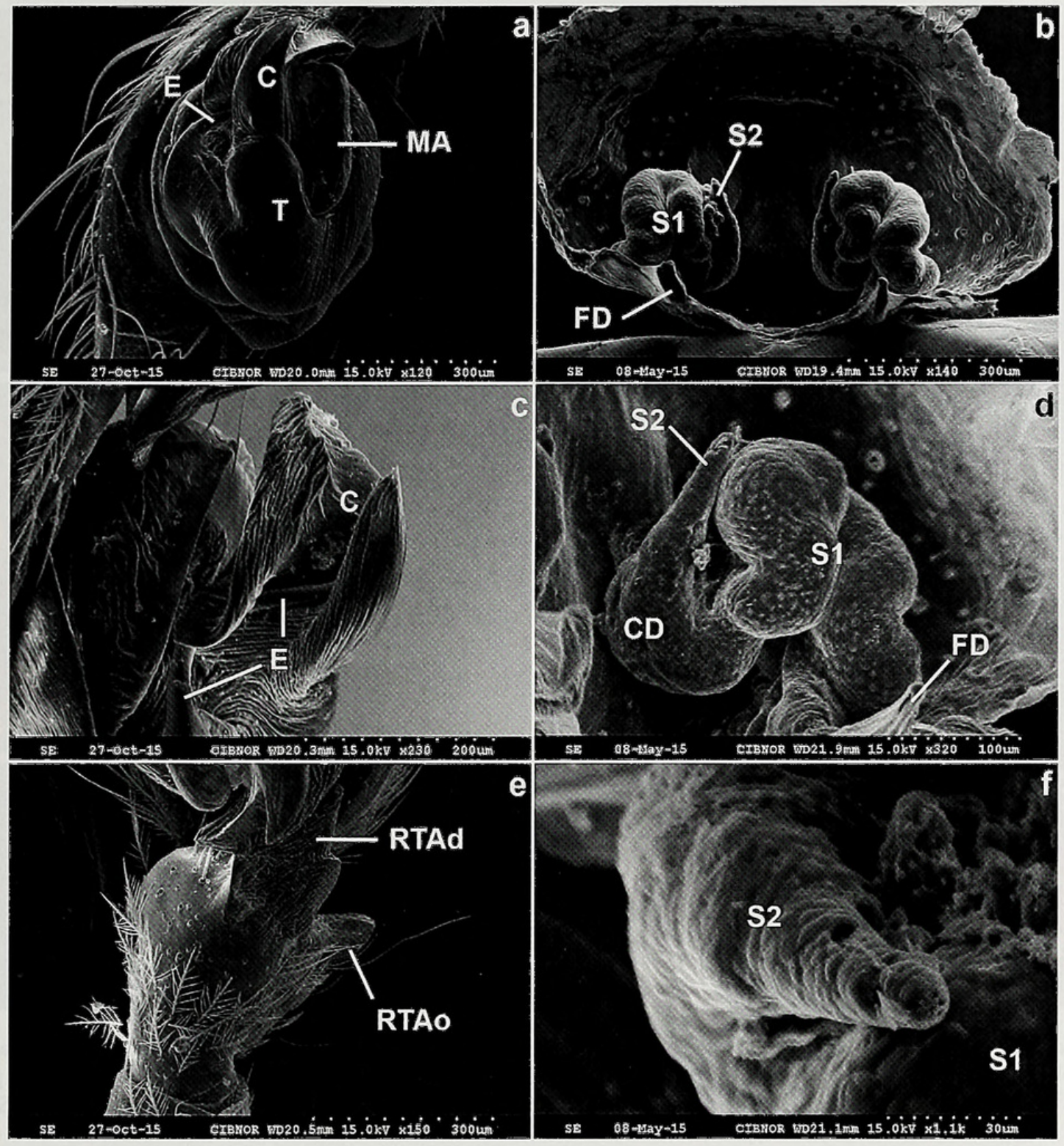

Figure 19.-Callidalena tijuana sp. nov., genitalia (SEM). a, c, e. Male pedipalp. b, d, f. Epigynum. Abbreviations: CD, copulatory ducts; E, embolus; FD, fertilization ducts; MA, median apophysis; RTAd, distal projection of RTA; RTAo, dorsal projection of RTA; S1, primary spermathecae; S2, secondary spermathecae; T, tegulum.

0 ; III- 1-1/ 1/ 1; IV- 1-1/ 1/ 1; tibia I- dorsal 0/ ventral 2-2-2/ prolateral 1-1-0/ retrolateral 1-1-0; II- 0/ 1-2-2/ 1-1-0/ 1-1-0; III- 1-1-0/ 2-2-2/ 1-1-0/ 1-1-0; IV- 1-1-0/ 1-1-1-2/ 1-1-0/ 1-1-0; metatarsus I- $0 / 2-2-2 / 0-1-0 / 0-1-1$; II- 1-2-0/ 2-2-2/ 0-1-0/ 0-11; III- 3-2-2/ 2-2-2/0-1-1/0-1-1; IV-2-1-2-2/1-1-1-2-2/0-1-1/01-1. Number of trichobothria on tarsus: I- 6, II- 6, III- 6, IV- 5.

Pedipalp: Number of dorsal spines: femur 3, tibia 3 . Cymbium length 1.24, width 0.7 . Embolus with stout base. Conductor with projections of similar size. One coil visible through the tegulum on mesal margin. RTA with two subprocesses on dorsal projection (Figs. 13a, c, e, 14a, b).

Variation.-Total body length in males varies between 5.63 and $6.88(n=8)$ and in females between 5.38 and $8.75(n=18)$. Carapace length in males varies between 2.75 and $4(n=9)$ and in females between 2.63 and $4.38(n=18)$. Patella-tibia I length in males varies between 3.38 and $4.38(n=9)$ and in females between 2.5 and $4.25(n=18)$. Specimens with a central band and three pairs of yellow spots on sternum.

Distribution.-Baja California Sur (Mexico) (Fig. 23b).

Cabolena sotol Maya-Morales, Jiménez \& Palacios-Cardiel sp. nov.

http://zoobank.org/?lsid=urn:lsid:zoobank.

org:act:A1962DE3-F6A0-46B9-9D72-AB7D35AA16FC

(Figs. 15, 16, 23b)

Type material.-Holotype female: Municipality of La Paz, Biosphere Reserve Sierra La Laguna, Cañón La Zorra, Baja California Sur, Mexico, 1640 m, 13 January 1988, V. Roth (CARCIB 36). Paratypes: MEXICO: Baja California Sur: 3 , same data as holotype (CARCIB 22); 1 \%, same data as holotype (CARCIB 3755); 3 ${ }^{*}$, same data as holotype except 10 May 1986, M.L. Jiménez (CARCIB 5); 1 đิ, same data except 12 February 1986 (CARCIB 1860); 1 ऽे, same data 

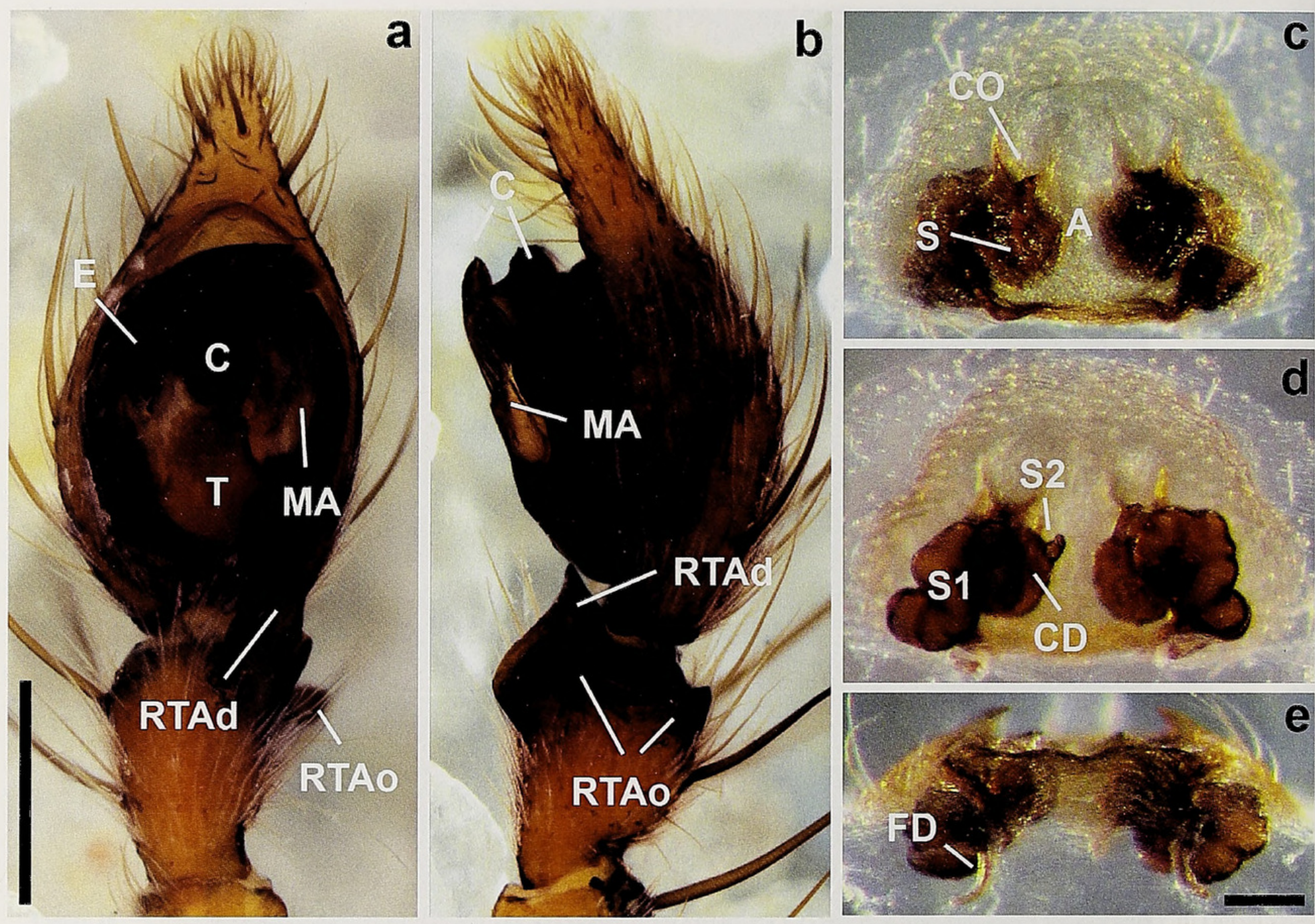

Figure 20.-Callidalena tijuana sp. nov., genitalia. a, b. Male pedipalp. c-e. Epigynum. a, c. Ventral view. b. Retrolateral view. d. Dorsal view. e. Posterior view. Abbreviations: C, conductor; CO, copulatory openings; E, embolus; FD, fertilization ducts; MA, median apophysis; RTAd, distal projection of RTA; RTAo, dorsal projection of RTA; S, spurs; S1, primary spermathecae; S2, secondary spermathecae. Scale bars: a $=0.5$ $\mathrm{mm} ; \mathrm{e}=0.15 \mathrm{~mm}$.

except F. Cota (CARCIB 3753); 1 đ, same data as holotype except 15 January 1988, V. Roth \& M.L. Jiménez (CARCIB 23); 1 o, 2 ㅇ, same data as holotype except 25 February 1984, F. Cota \& M.L. Jiménez (CARCIB 38); 1 đิ, same data except

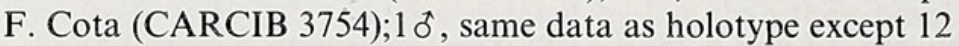
December 1986, M. Acevedo (CARCIB 1862); 1 \%, same data as holotype except Valle La Laguna, 1830 m, 20 April 1988, M.L. Jiménez \& R. Domínguez (CARCIB 1868); 1 , same data as holotype except Las Cascadas, $23^{\circ} 32^{\prime} 56.9^{\prime \prime} \mathrm{N}$, $109^{\circ} 58^{\prime} 07.6^{\prime \prime} \mathrm{W}, 1734 \mathrm{~m}$, hand collecting on ground, 8 October 2011, C. Palacios, J. Maya \& J. Villarreal (CARCIB 1881); 1 $\uparrow$, same data as holotype except Arroyo La Palma, $23^{\circ} 34^{\prime} 24.8^{\prime \prime} \mathrm{N}, 109^{\circ} 58^{\prime} 27^{\prime \prime} \mathrm{W}, 1798 \mathrm{~m}$, hand collecting on ground, 6 October 2011, C. Palacios, J. Maya \& J. Villarreal (CARCIB 1883); 3 б, same data as holotype except Palo Extraño, 14 April 1986, A. \& F. Cota (CARCIB 25).

Other material examined.-MEXICO: Baja California Sur: 2 \&, same data as holotype except 12 December 1986, A. Acevedo (CARCIB 26); 1 \%, same data except 4 March 1986, F. \& A. Cota (CARCIB 30); 1 , same data except 12 April 1986, M.L. Jiménez (CARCIB 33); 1 \%, same data except 3 July 1986, A. Cota (CARCIB 35); 2 , same data as holotype except Palo Extraño, 1840 m, 13 January 1988, F. Cota (CARCIB 10); 1 으, same data except 21 March 1988, A. \& F. Cota (CARCIB 31); 1 ơ, 3 \%, same data except $1640 \mathrm{~m}, 13$ January 1988, V. Roth (CARCIB 37); 2 o, 1 ㅇ, same data as holotype except Paso La Golondrina, 13 January 1987, V. Roth \& M.L. Jiménez (CARCIB 15); 2 \%, same data as holotype except Valle La Laguna, 6 June 1988, A. Cota (CARCIB 21); 1 \%, same data except 27 September 1987, F. Cota (CARCIB 1856); 3 \&, same data except 13 January 1984, V. Roth (CARCIB 1857); 1 ㅇ, same data except 1630 m, 29 September 1987, A. Cota \& M.L. Jiménez (CARCIB 29); 1 ㅇ, same data as holotype except Arroyo La Palma, 1640 m, 11 December 1986, A. Acevedo (CARCIB 1866); 1 \%, same data as holotype except road to La Palma, 23⒊'22.6" $\mathrm{N}$, $109^{\circ} 58^{\prime} 43.5^{\prime \prime} \mathrm{W}, 1818 \mathrm{~m}$, beat sheet, 5 October 2011, C. Palacios, J. Maya \& J. Villarreal (CARCIB 1884); 1 q, same data (CARCIB 1902); 1 \%, same data (CARCIB 1910); 1 , same data as holotype except Cerro Madroñito, $23^{\circ} 32^{\prime} 58^{\prime \prime} \mathrm{N}$, $109^{\circ} 58^{\prime} 05^{\prime \prime} \mathrm{W}, 1812 \mathrm{~m}, 3$ November 2006, C. Palacios (CARCIB 2521).

Etymology.- The specific name refers to the "sotol" plant (Nolina beldingii), where the species was found. 


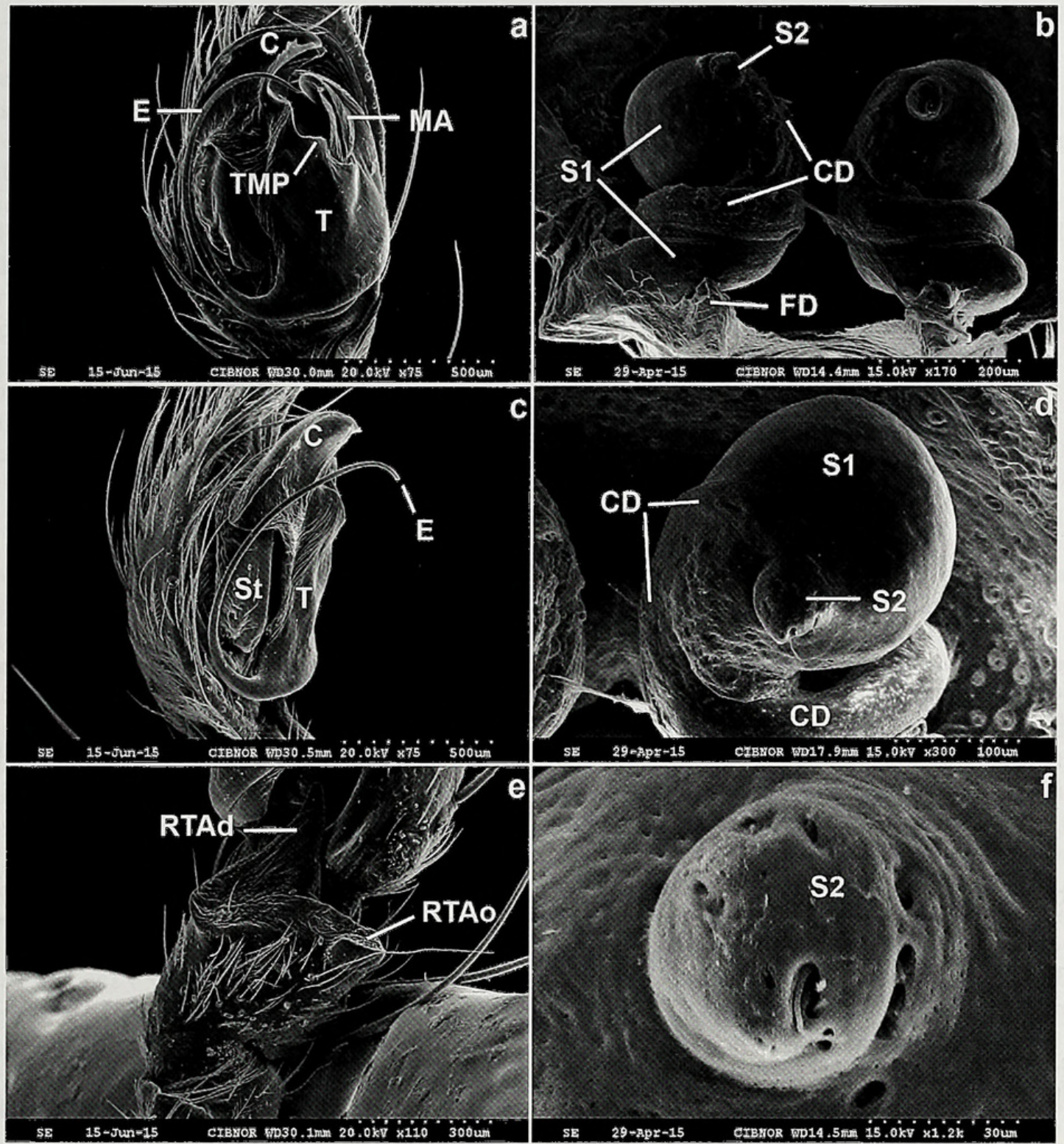

Figure 21.-Lagunella guaycura sp. nov., genitalia (SEM). a, c, e. Male pedipalp. b, d, f. Epigynum. Abbreviations: C, conductor; CD, copulatory ducts; E, embolus; FD, fertilization ducts; MA, median apophysis; RTAd, distal projection of RTA; RTAo, dorsal projection of RTA; S1, primary spermathecae; S2, secondary spermathecae; St, subtegulum; T, tegulum; TMP, tegular median process.

Diagnosis.-Females of this species differ from C. huiztocatl by having the median plate of the epigynum wider and less sclerotized (Fig. 16c); and from C. kosatli by having smaller copulatory openings which are not visible in ventral view (Fig. 16c) and bean-shaped primary spermathecae with the anterior part wider than the posterior part (Fig. 16d). Males differ from $C$. huiztocatl and C. kosatli by the absence of any visible spermophore coils through the tegulum (Fig. 16a).

Description.-Female (holotype): Coloration: Carapace yellow, cephalic region brown, with white feathery scale-like setae. Chelicerae dark brown. Condyles orange. Endites and labium brown with white tips. Sternum yellow. Legs yellow, tibia-metatarsus I-II brown. Opisthosoma light brown with an anterior reddish spot and several lateral brown spots. Spinnerets yellow.

Habitus: Total length 10. Carapace length 4.5 , width 3.63 , cephalic region width 1.86 , ocular region width 0.81 . Eye diameter: AME 0.15, ALE 0.19, PME 0.13, PLE 0.17.
Distance between eyes: AME-AME 0.08, AME-ALE 0.08, AME-PME 0.19, ALE-PLE 0.06, ALE-ALE 0.33, PME-PME 0.12 , PME-PLE 0.13. Clypeus height 0.27. Chelicerae with three retromarginal teeth; basal segment length 1.67 , fang length 0.62 . Labium as long as wide $(0.62 / 0.62)$. Endites slightly convergent (distance at their base compared to their tips $0.62 / 0.38)$. Sternum longer than wide (2.14/1.81). Opisthosoma longer than wide (5/3.13). ALS separated by less than their basal diameter $(0.27 / 0.36)$, PLS with distal segment as long as basal segment $(0.36 / 0.36)$.

Legs: Length: I- femur 3.5/ patella-tibia 4.38/ metatarsus $3.25 /$ tarsus 2.13; II- 3.38/4.13/3.13/ 1.88; III- 3.38/4.13/ 3.5 1.5; IV- 4.13/5.38/5/2.13.

Spination: Femur dorsal I- 1-2-3/ II- 1-3-3/ III- 1-3-3/ IV- 12-3; patella I- dorsal 1-1/ prolateral $1 /$ retrolateral 0 ; II- 1-1/ 1 / 0 ; III- $1-1 / 1 / 1$; IV- 1-1/ 1/ 1; tibia I- dorsal 0/ ventral 2-2-2/ prolateral 1-1-0/ retrolateral 0 ; II- $0 / 2-2-2 / 1-1-0 / 1-0-0$; III- 1 $1-0 / 1-2-2 / 1-1-0 /$ 1-1-0; IV- $1-1-0 / 1-2-2 / 1-1-0 / 1-1-0$; 

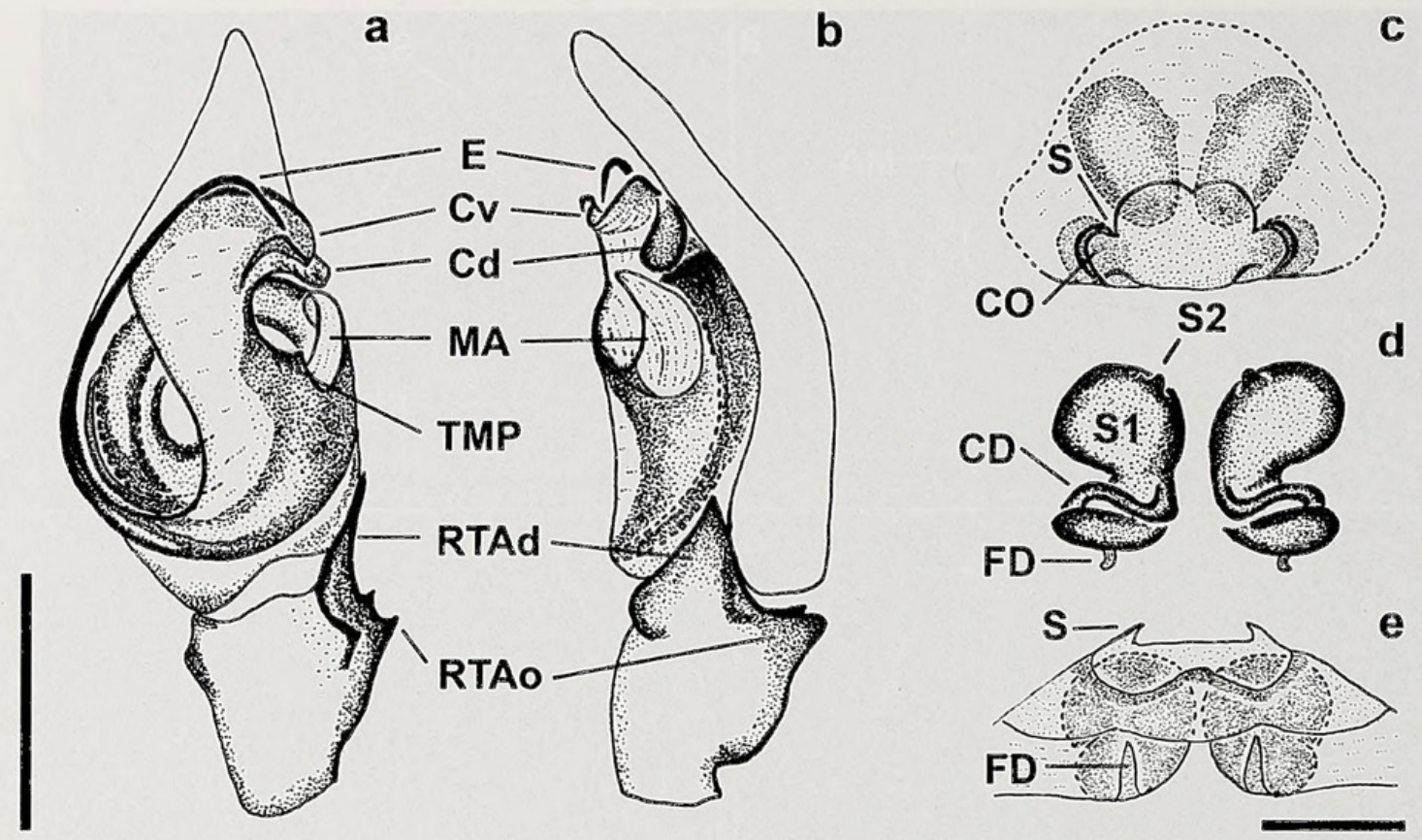

Figure 22.-Lagunella guaycura sp. nov., genitalia. a, b. Male pedipalp. c-e. Epigynum. a, c. Ventral view. b. Retrolateral view. d. Dorsal view. e. Posterior view. Abbreviations: CD, copulatory ducts; Cd, dorsal projection of conductor; CO, copulatory openings; $\mathrm{Cv}$, ventral projection of conductor; E, embolus; FD, fertilization ducts; MA, median apophysis; RTAd, distal projection of RTA; RTAo, dorsal projection of RTA; S, spurs; S1, primary spermathecae; S2, secondary spermathecae; TMP, tegular median process. Scale bars: $a=0.5 \mathrm{~mm}$; e =0.35 mm.
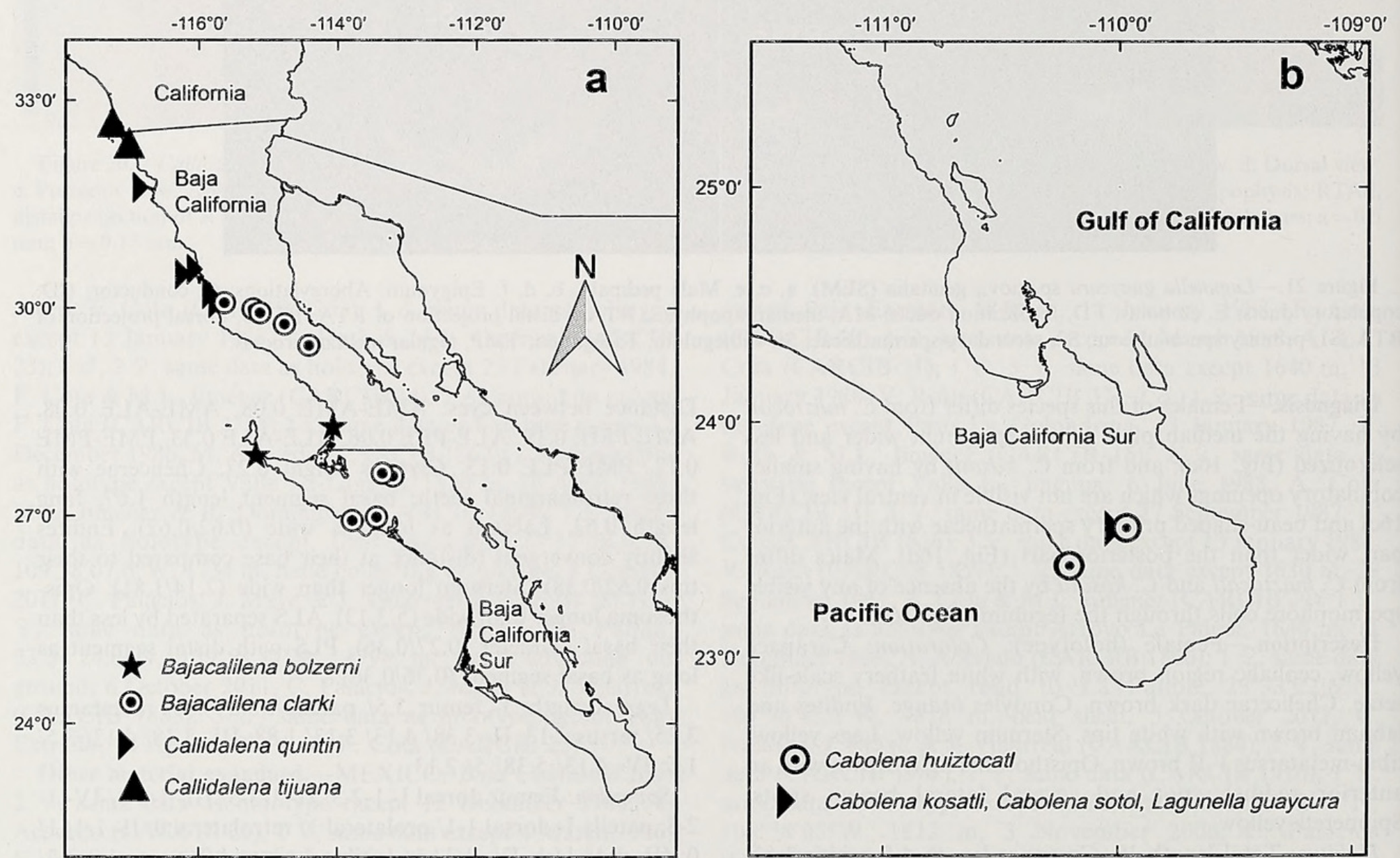

Figure 23.- a. Map showing distribution of Bajacalilena bolzerni sp. nov., B. clarki sp. nov., Callidalena quintin sp. nov. and C. tijuana sp. nov. b. Map showing distribution of Cabolena huiztocatl sp. nov., C. kosatli sp. nov., C. sotol sp. nov. and Lagunella guaycura sp. nov. 
metatarsus I- 0/ 2-2-2/ 0-1-0/ 0-0-1; II- 0/ 2-2-2/ 0-1-1/ 0-1-1; III- 3-1-2/ 2-2-2/ 0-1-1/ 0-1-1; IV- 3-2-2/ 1-1-1-2-2/ 0-1-1/ 0-11. Number of trichobothria on tarsus: I- 7, II- 7, III- 7, IV- 7 .

Pedipalp: Dorsal spines on femur: 3. Prolateral spines on tibia: $1-2$.

Epigynum: Plate length 0.67 , width 1.09. In posterior view, median plate narrower toward ventral margin. Copulatory openings as small holes visible in anterior view. Bean-shaped primary spermathecae, wider at anterior part, and separated by less than their width (Figs. 15b, d, f, 16c-e).

Male (paratype from holotype locality) (CARCIB 5): Coloration: Carapace yellow, cephalic region brown. Chelicerae brown. Condyles orange. Endites and labium light brown with white tips. Sternum yellow. Femur yellow, patella-tarsus orange. Opisthosoma similar to female, spots darker. Spinnerets yellow, basal segment of PLS with black spots.

Habitus: Total length 7.38. Carapace length 4.25, width 2.5, cephalic region width 1.27 , ocular region width 0.76 . Eye diameter: AME 0.13, ALE 0.21, PME and PLE 0.19. Distance between eyes: AME-AME 0.06, AME-ALE 0.06, AME-PME 0.17 , ALE-PLE 0.04, ALE-ALE 0.31, PME-PME 0.08, PMEPLE 0.08. Clypeus height 0.25 . Chelicerae with three retromarginal teeth; basal segment length 1.42 , fang length 0.64 . Labium slightly longer than wide $(0.52 / 0.48)$. Endites slightly convergent (distance at their base compared to their tips 0.48 / $0.29)$. Sternum longer than wide $(2 / 1.48)$. Opisthosoma longer than wide $(3.75 / 2)$. ALS separated by their basal diameter $(0.24 / 0.24)$, PLS with distal segment slightly shorter than basal segment $(0.42 / 0.45)$.

Legs: Length: I- femur 3.5/ patella-tibia 4.38/ metatarsus 3.5/ tarsus 2.5; II- 3.5/3.88/3.5/2.13; III- 3.5/ 4.25/3.63/2.25; IV- $4.38 / 5.38 / 5.5 / 2.5$.

Spination: Femur dorsal I- 1-2-3/ II- 1-3-3/ III- 1-3-3/ IV- 12-3; patella I- dorsal $1-1 /$ prolateral $1 /$ retrolateral 0 ; II- $1-1 / 1$ / 0 ; III- 1-1/ 1/ 1; IV- 1-1/ 1/ 1; tibia I- dorsal 0/ ventral 2-2-2/ prolateral 1-1-0/ retrolateral 0-1-1; II- $0 / 1-2-2 / 1-1-0 / 1-1-0$; III- 1-1-0/ 2-2-2/ 1-1-0/ 1-1-0; IV- 1-1-0/ 1-2-2/ 1-1-0/ 1-1-0; metatarsus I- $0 / 2-2-2 / 0-1-1 / 0-1-1$; II- $0 / 2-2-2 / 0-1-1 / 0-1-1$; III- 3-2-2/ 2-2-2/ 0-1-1/ 0-1-1; IV- 3-2-2/ 2-1-1-2/ 0-1-1/ 0-0-1. Number of trichobothria on tarsus: I- 6, II- 6, III- 5, IV- 5 .

Pedipalp: Number of dorsal spines: femur 3, tibia 4 . Cymbium length 1.33 , width 0.76 . Embolus uniformly slender. Conductor with dorsal projection slightly longer than ventral one. Tegular median process present. RTA with two subprocesses on dorsal projection (Figs. 15a, c, e, 16a, b).

Variation.-Total body length in males varies between 6.63 and $8.75(n=10)$ and in females between 7.5 and $12.13(n=$ 10). Carapace length in males varies between 3.13 and $4.5(n=$ $10)$ and in females between 3.38 and $5.13(n=10)$. Patella-tibia I length in males varies between 3.88 and $5.38(n=10)$ and in females between 3.63 and $5.13(n=10)$. Some paratypes with four retromarginal teeth on chelicerae.

Distribution.-Baja California Sur (Mexico) (Fig. 23b).

Callidalena Maya-Morales \& Jiménez gen. nov. http://zoobank.org/?lsid=urn:lsid:zoobank. org:act:BDD8A68E-C793-4169-AA0B-28DE3332BCB1

Type species.-Callidalena quintin $\mathrm{sp}$. nov.
Etymology.-The generic name is derived from Latin "Callida" which means "hot" and is part of the origin of the word California. The gender is feminine.

Diagnosis.-Callidalena gen. nov. is diagnosed by the following characters in combination: male pedipalp with the embolus sinuous and supported by a folded conductor which has a deep ventral notch (Figs. 18a, 20a); and RTA confined to the distal part of the tibia and composed of two projections, one distal and one lateral across the tibia (Figs. 17e, 20b). Epigynum with an inverse $\mathrm{T}$-shaped appearance in ventral view (Fig. 18c); spurs in a lateral position (Fig. 20c); copulatory openings at anterior position of plate (Fig. 20c); copulatory ducts short (Fig. 19d) and ventrally position relative to the folded primary spermathecae (Figs. 17b, 19b); and secondary spermathecae in diverticula (Figs. 17f, 19d).

Callidalena gen. nov. differs from Eratigena and Tegenaria by having strongly procurved eye rows in frontal view; from Agelenopsis, Barronopsis, Melpomene and Tortolena by having the embolus slightly curved and by the absence of a tegular lateral process; from Hoffmannilena by having the RTA on the distal part of the tibia and the epigynum poorly sclerotized; from Novalena by having a ridge on the dorsal projection of the RTA and by the folded primary spermathecae; from Calilena by the absence of both a fulcrum at the base of the embolus and a scape on the epigynum; from Hololena by having the embolus supported by the conductor only and by the shape of the epigynum, which has an inverse T-shaped appearance in ventral view; from Rothilena by having the embolus sinuous and supported by a folded conductor with a deep ventral notch and by the absence of hoods on the epigynal atrium; from Bajacalilena gen. nov. by having the embolus sinuous and the primary spermathecae folded; from Cabolena by having the RTA on the distal part of the tibia and by the shape of the epigynum, which has an inverse T-shaped appearance in ventral view; and from Rualena by the absence of both a membranous fulcrum and a thickened ridge on the posterior margin of the epigynal atrium.

Description.-Medium sized spiders, $4-9 \mathrm{~mm}$ in total length. Both eye rows strongly procurved in frontal view. Feathery scale-like setae present on carapace, opisthosoma, pedipalps, and legs. Carapace with two longitudinal symmetrical dark bands intensified by feathery setae, a black band around the border of thoracic region, and a clear median band wider on cephalic region. Chelicerae with three promarginal teeth and two retromarginal teeth. Sternum longer than wide. Pedipalp femur usually with two dorsal spines. Legs with spines and longer in males than in females. Leg IV the longest. Rings present on femur, patella and tibia. Patella-tibia I usually longer than carapace in males and shorter than carapace in females. Patella I and II with two dorsal spines and one prolateral spine, patella III and VI with two dorsal spines, one prolateral spine, and one retrolateral spine. Leg tarsi with five to six trichobothria. Capsulate tarsal organ in distal position of trichobothrial row. Opisthosoma oval with dorsal foliate pattern and/or posterior chevrons. Colulus divided, represented by few hairs. PLS longest with distal segment as long as or slightly longer than basal. Male pedipalp with folded conductor (Fig. 19c) with a deep ventral notch, forming two projections, the ectal one the longest (Fig. 18a). Median apophysis an elongated, spoon-shaped membrane (Fig. 19a). 
RTA with a distal projection and a lateral projection across the tibia (Fig. 18b). Tibia with prolaterodorsal protuberance. Epigynal plate wider than long with an inverse $\mathrm{T}$-shaped appearance in ventral view (Fig. 18c). Lateral hyaline spurs present (Fig. 20c). Copulatory openings in anterior position (Fig. 18c). Copulatory ducts short, in ventral position in relation to primary spermathecae (Fig. 17b). Primary spermathecae folded (Figs. 18d, 20d). Secondary spermathecae in diverticula (Figs. 17d, 19f). Fertilization ducts short (Fig. 19b).

Distribution.-Callidalena gen. nov. is distributed in the USA in the State of California and in Mexico in the State of Baja California (Fig. 23a).

Included taxa.-Two species: $C$. quintin sp. nov. and $C$. tijuana sp. nov.

Callidalena quintin Maya-Morales \& Jiménez sp. nov. http://zoobank.org/?lsid=urn:lsid:zoobank. org:act:0350041E-8FBC-418C-8043-0311A4A5A73A (Figs. 17, 18, 23a)

Type material.-Holotype male: Municipality of Ensenada, San Quintín, Baja California, Mexico, 24 November 1962, P.R. Craig \& D.L. Dailey (CASENT 9048919). Paratypes: MEXICO: Baja California: 2 , same data as holotype (CASENT 9048919); 1 , same data as holotype (CASENT 9048917); 2 , same data as holotype (CASENT 9048918); 1 ๙, 2 o, same data as holotype except 23 November 1962 (CASENT 9048912); 1 ð, same data (CASENT 9048914); 1 ðे, same data (CASENT 9048915); 1 \&, Punta Banda, 2 December 1973, S.C. Williams \& C.L. Mullinex (CASENT 9048921); 1 đo, Isla San Martín, 30 June 1983, V.F. Lee (CASENT 9048922); 1 ð, 2 क, $17.2 \mathrm{~km} \mathrm{~N}$. of El Rosario, 25 November 1962, P.R. Craig \& D.L. Dailey (CASENT 9048924); 1 o, $11.7 \mathrm{~km} \mathrm{E.} \mathrm{of} \mathrm{El} \mathrm{Rosario,} 30^{\circ} 04^{\prime} 30^{\prime \prime} \mathrm{N}$, $115^{\circ} 37^{\prime} 55^{\prime \prime} \mathrm{W}, 180 \mathrm{~m}$, pitfall trap, 7 January 1984 - 2 March 1986, W.H. Clark (CIDA 98,372); 1 ऽ, same data except 3 January - 27 August 1989 (CIDA 99,732); 2 đo, same data except 7 February 1984 - 2 April 1985, W.H. Clark \& P.E. Blom (CIDA 107,417); 1 ๙。, same data (CIDA 107,454); 3 \%, same data (OJSMNH); 1 ๙, $10.7 \mathrm{~km} \mathrm{E.} \mathrm{of} \mathrm{El} \mathrm{Rosario,}$ $30^{\circ} 04^{\prime} 35^{\prime \prime} \mathrm{N}, 115^{\circ} 38^{\prime} 25^{\prime \prime} \mathrm{W}, 160 \mathrm{~m}$, pitfall trap, 7 February 1984 - 2 April 1985, W.H. Clark (CIDA 107,432).

Etymology.-The specific name is a noun in apposition taken from the type locality.

Diagnosis.-Males of this species differ from C. tijuana by having the ventral notch of the conductor deeper and wider (Fig. 18a) and by the more pronounced curves of the embolus (Fig. 17c). Females differ from C. tijuana by having copulatory openings occupying two-thirds of the anterior part of the epigynal plate (Fig. 18c) and primary spermathecae with a single pronounced curve (Fig. 17b)

Description.-Male (holotype): Coloration: Carapace yellow, black spot between AME. Chelicerae and condyles yellow. Endites and labium yellow with white tips. Sternum yellow with greyish border. Legs yellow, distal part of metatarsus brown. Opisthosoma greyish, brown anterior spot, lateral white spots, white foliage, and five pairs of lateral dark brown spots. Spinnerets yellow, basal segment of PLS with diffuse spots.

Habitus: Total length 4.63. Carapace length 2.5, width 1.38, cephalic region width 1.21 , ocular region width 0.52 . Eye diameter: AME, ALE, PME and PLE 0.1. Distance between eyes: AME-AME 0.06, AME-ALE 0.04, AME-PME 0.1, ALE-PLE 0.04, ALE-ALE 0.23, PME-PME 0.08, PME-PLE 0.08 . Clypeus height 0.13 . Chelicerae: basal segment length 0.91 , fang length 0.45 . Labium wider than long $(0.39 / 0.24)$. Endites slightly convergent (distance at their base compared to their tips $0.39 / 0.33)$. Sternum longer than wide $(1.1 / 0.95)$. Opisthosoma longer than wide $(2.1 / 1.05)$. ALS separated by their basal diameter $(0.19 / 0.19)$, PLS with distal segment slightly longer than basal segment $(0.48 / 0.42)$.

Legs: Length: I- femur $1.92 /$ patella-tibia $2.31 /$ metatarsus $1.77 /$ tarsus 1.54 ; II- $2.08 / 2.46 / 2.23 / 1.62$; III- $2.15 / 2.62 / 2.38 /$ 1.38; IV- $2.85 / 3.54 / 3.62 / 1.92$.

Spination: Femur dorsal I- 1-1-2/ II- 1-3-2/ III- 1-3-2/ IV- 12-2; patella I- dorsal 1-1/ prolateral $1 /$ retrolateral 0 ; II- 1-1/ 1 / 0 ; III- $1-1 / 1 / 1$; IV- 1-1/ 1/ 1; tibia I- dorsal 1-1-0/ ventral 2-2$2 /$ prolateral 1-1-0/ retrolateral 0; II- 1-1-0/ 1-2-2/ 1-1-0/ 0; III$1-1-0 / 1-1-2 / \quad 1-1-0 / 1-1-0 ;$ IV- 1-1-0/ 1-2-2/ 1-1-0/ 1-1-0; metatarsus I- 0/ 2-2-2/ 1-0-0/ 0-1-1; II- 0-0-1/ 2-2-2/ 0-1-1/ 0-10 ; III- 3-1-2/ 2-2-2/ 0-1-1/ 0-1-1; IV-3-1-2/ 1-1-1-2-2/ 0-1-1/ 0 1-1. Number of trichobothria on tarsus: I- 5, II- 5, III- 5, IV- 5 .

Pedipalp: Number of dorsal spines: femur 2, tibia 4. Cymbium length 0.77 , width 0.48 . Embolus sinuous with a strong curve, exceeding distally the conductor ventral notch. The notch is deep extending two-thirds the conductor length (Figs. 17a, c, e, 18a, b).

Female (paratype from holotype locality) (CASENT 9048919): Coloration: Carapace yellow. Chelicerae light brown. Condyles orange. Endites and labium orange with white tips and small brown spots. Sternum yellow with brown border. Femur yellow, patella-tarsus light brown. Opisthosoma light brown with an anterior brown spots, several pairs of groups of white spots, and four pairs of lateral dark brown spots. Spinnerets orange.

Habitus: Total length 8.75. Carapace length 3.75 , width 2.38 , cephalic region width 1.36 , ocular region width 0.76 . Eye diameter: AME 0.13, ALE and PLE 0.15, PME 0.17. Distance between eyes: AME-AME 0.08, AME-ALE 0.06, AME-PME 0.17, ALE-PLE 0.06, ALE-ALE 0.33, PME-PME 0.1, PMEPLE 0.1. Clypeus height 0.21. Chelicerae: basal segment length 1.57, fang length 0.67 . Labium wider than long $(0.55 / 0.39)$. Endites slightly convergent (distance at their base compared to their tips $0.55 / 0.33)$. Sternum longer than wide $(1.76 / 1.43)$. Opisthosoma longer than wide $(4.75 / 2.88)$. ALS separated by less than their basal diameter $(0.24 / 0.3)$, PLS with distal segment as long as basal segment $(0.39 / 0.39)$.

Legs: Length: I- femur 3/ patella-tibia 3.38/ metatarsus $2.38 /$ tarsus 1.75 ; II- 2.88/3.13/ 2.5/ 1.75; III- 2.5/ 3.38/ 2.75/ 1.5; IV- 3.75/4.38/4.13/ 1.88 .

Spination: Femur dorsal I- 1-1-2/ II- 1-3-2/ III- 1-3-2/ IV- 1$1-2$; patella I- dorsal 1-1/ prolateral $1 /$ retrolateral 0 ; II- 1-1/ 1 / 0 ; III- 1-1/ 1/ 1; IV- 1-1/ 1/ 1; tibia I- dorsal 1-1-0/ ventral 2-2$2 /$ prolateral 1-1-0/ retrolateral 0 ; II- 1-1-0/ 2-2-2/ 1-1-0/ 0; III1-1-0/ 2-2-2/ 1-1-0/ 1-1-0; IV- 1-1-0/ 2-2-2/ 1-1-0/ 1-1-0; metatarsus I- 0/ 2-2-2/ 0-1-1/ 0; II- 0/ 2-2-2/ 0-1-1/ 0; III- 3-1-2/ $2-2-2 / 0-1-1 / 0-1-1$; IV- 3-1-2/ 1-1-1-2-2/ 0-1-1/ 0-1-1. Number of trichobothria on tarsus: I- 5, II- 5, III- 5, IV- 5 .

Pedipalp: Dorsal spines on femur: 1. Prolateral spines on tibia: $1-2$. 
Epigynum: Plate length 0.58 , width 0.91 . Copulatory openings rounded separated by less than their width. Copulatory ducts less sclerotized than spermathecae. Primary spermathecae with one pronounced curve at anterior part where the copulatory ducts are connected. Primary spermathecae separated by less than their width (Figs. 17b, d, f, 18cd).

Variation.-Total body length in males varies between 4.63 and $6.75(n=15)$ and in females between 5.38 and $8.75(n=$ 10). Carapace length in males varies between 2.38 and $3.75(n$ $=15)$ and in females between 2.63 and $3.75(n=10)$. Patellatibia I length in males varies between 2.31 and $4(n=13)$ and in females between 2.38 and $3.38(n=10)$. Paratypes with three to four pairs of brown spots on sternum.

Distribution.-Baja California (Mexico) (Fig. 23a).

Callidalena tijuana Maya-Morales \& Jiménez sp. nov. http://zoobank.org/?lsid=urn:lsid:zoobank.

org:act:324FFC1A-1015-4DE5-AFD6-5AA17834FE92 (Figs. 19, 20, 23a)

Type material.-Holotype male: Highway \#1 km 47, Baja California, Mexico, 20 November 1962, P.R. Craig \& D.L. Dailey (CASENT 9048909). Paratypes: MEXICO: Baja California: 1 \&, same data as holotype (CASENT 9048909); 2 \&, $3.4 \mathrm{~km} \mathrm{~S}$. of Tijuana, Highway \#1 km 35, 10 November 1962, P.R. Craig \& D.L. Dailey (CASENT 9048908); 1 , same data except $4 \mathrm{~km} \mathrm{~S}$. of Tijuana, under stone, 21 November 1962, (CASENT 9048910); 1 , same data (CASENT 9048911). USA: California: 1 o, San Diego Co., Naval Base Point Loma, 32 $41^{\prime} 22.45^{\prime \prime} \mathrm{N}, 117^{\circ} 14^{\prime} 30.52^{\prime \prime} \mathrm{W}$, pitfall trap, 10 August 2009, Naval Base Point Loma team (SDNHM a000797); 1 \%, same data except 26 May 2009 (SDNHM a000842); 1 \%, same data except $32^{\circ} 41^{\prime} 35.95^{\prime \prime} \mathrm{N}$, $117^{\circ} 15^{\prime} 09.17^{\prime \prime} \mathrm{W}, 30$ March 2009 (SDNHM a000808); 1 , same data except 11 May 2009 (SDNHM a000858); 1 ठै, same data except $32^{\circ} 42^{\prime} 35.64^{\prime \prime} \mathrm{N}, 117^{\circ} 15^{\prime} 09.13^{\prime \prime} \mathrm{W}, 27$ February 2009 (SDNHM a000811); $10^{\star}$, same data except $32^{\circ} 41^{\prime} 45.74^{\prime \prime} \mathrm{N}$, $117^{\circ} 14^{\prime} 36.24^{\prime \prime} \mathrm{W}, 21$ December 2009 (SDNHM a000843); 1 क, same data except $32^{\circ} 41^{\prime} 28.83^{\prime \prime} \mathrm{N}, 117^{\circ} 14^{\prime} 55.01^{\prime \prime} \mathrm{W}, 13$ July 2009 (SDNHM a000860); 1 \&, same data except $32^{\circ} 41^{\prime} 50.24^{\prime \prime} \mathrm{N}, 117^{\circ} 14^{\prime} 42.07^{\prime \prime} \mathrm{W}, 15$ June 2000 (SDNHM a000872); 1 o, same data except $32^{\circ} 41^{\prime} 27.85^{\prime \prime} \mathrm{N}$, $117^{\circ} 14^{\prime} 55.11^{\prime \prime} \mathrm{W}, 29$ June 2009 (SDNHM a000862); 1 o, same data except $32^{\circ} 41^{\prime} 35.64^{\prime \prime} \mathrm{N}, 117^{\circ} 15^{\prime} 09.13^{\prime \prime} \mathrm{W}, 18$ February 2010 (SDNHM a000868); 1 ठ", same data except 30 March 2009 (SDNHM a000859); 1 \&, same data except $32^{\circ} 41^{\prime} 28.05^{\prime \prime} \mathrm{N}$, $117^{\circ} 15^{\prime} 14.68^{\prime \prime} \mathrm{W}, 18$ February 2010 (SDNHM a000861); 1 क, same data except $32^{\circ} 41^{\prime} 52.45^{\prime \prime} \mathrm{N}, 117^{\circ} 14^{\prime} 59.26^{\prime \prime} \mathrm{W}, 19$ October 2009 (SDNHM a000856); 1 ơ, same data except $32^{\circ} 41^{\prime} 02.49^{\prime \prime} \mathrm{N}, 117^{\circ} 14^{\prime} 49.14^{\prime \prime} \mathrm{W}, 27$ April 2009 (SDNHM a000867).

Other material examined.-USA: California: San Diego Co., Naval Base Point Loma, 32 $41^{\prime} 49.88^{\prime \prime} \mathrm{N}, 117^{\circ} 14^{\prime} 41.57^{\prime \prime} \mathrm{W}$, pitfall trap, 24 August 2009, Naval Base Point Loma team, 2 ơ (SDNHM a000859); 1 ठ, same data except $32^{\circ} 41^{\prime} 28.99^{\prime \prime} \mathrm{N}$, $117^{\circ} 14^{\prime} 55.25^{\prime \prime} \mathrm{W}, 10$ August 2009 (SDNHM a000793); 1 ऊ, same data except $32^{\circ} 41^{\prime} 28.22^{\prime \prime} \mathrm{N}, 117^{\circ} 14^{\prime} 55.09^{\prime \prime} \mathrm{W}$ (SDNHM a000794); 2 o, same data except 27 July 2009 (SDNHM a000801); 1 o, same data except $32^{\circ} 41^{\prime} 24.41^{\prime \prime} \mathrm{N}$, $117^{\circ} 15^{\prime} 19.45^{\prime \prime} \mathrm{W}, 10$ August 2009 (SDNHM a000795); 1 \%, same data except $32^{\circ} 41^{\prime} 09.28^{\prime \prime} \mathrm{N}, 117^{\circ} 14^{\prime} 28.43^{\prime \prime} \mathrm{W}$ (SDNHM a000796); 1 o, same data except $32^{\circ} 42^{\prime} 13.44^{\prime \prime} \mathrm{N}$, $117^{\circ} 15^{\prime} 11.15^{\prime \prime} \mathrm{W}, 16$ March 2009 (SDNHM a000803); $1 \delta^{\circ}$, same data except $32^{\circ} 42^{\prime} 35.82^{\prime \prime} \mathrm{N}, 117^{\circ} 15^{\prime} 08.9^{\prime \prime} \mathrm{W}, 6$ April 2009 (SDNHM a000805); 1 \%, same data except $32^{\circ} 42^{\prime} 35.64^{\prime \prime} \mathrm{N}$, $117^{\circ} 15^{\prime} 09.13^{\prime \prime} \mathrm{W}, 16$ March 2009 (SDNHM a000804); 1 б, same data except $32^{\circ} 42^{\prime} 36.23^{\prime \prime} \mathrm{N}, 117^{\circ} 15^{\prime} 09.05^{\prime \prime} \mathrm{W}, 27$ July 2009 (SDNHM a000802); 1 o, same data except 30 March 2009 (SDNHM a000874); 1 $\delta$, same data except $32^{\circ} 41^{\prime} 03.06^{\prime \prime} \mathrm{N}, 117^{\circ} 14^{\prime} 49.35^{\prime \prime} \mathrm{W}, 16$ March 2009 (SDNHM a000807); 1 o, same data except $32^{\circ} 41^{\prime} 43.74^{\prime \prime} \mathrm{N}$, $117^{\circ} 15^{\prime} 09.19^{\prime \prime} \mathrm{W}, 27$ February 2009 (SDNHM a000810); 1 \%, same data except $32^{\circ} 41^{\prime} 02.49^{\prime \prime} \mathrm{N}, 117^{\circ} 14^{\prime} 49.14^{\prime \prime} \mathrm{W}, 30$ March 2009 (SDNHM a000809); 1 o , same data except 11 May 2009 (SDNHM a000866); $1 \delta^{\circ}$, same data except $32^{\circ} 41^{\prime} 52.78^{\prime \prime} \mathrm{N}$, $117^{\circ} 14^{\prime} 59.26^{\prime \prime} \mathrm{W}, 27$ February 2009 (SDNHM a000813); 1 , same data except $32^{\circ} 42^{\prime} 36.45^{\prime \prime} \mathrm{N}, 117^{\circ} 15^{\prime} 08.85^{\prime \prime} \mathrm{W}$ (SDNHM a000812); 1 oे, same data except 26 May 2009 (SDNHM a000841); 1 \&, same data except $32^{\circ} 42^{\prime} 28.05^{\prime \prime} \mathrm{N}$, $117^{\circ} 15^{\prime} 14.68^{\prime \prime} \mathrm{W}$ (SDNHM a000839); 1 \% , same data except $32^{\circ} 41^{\prime} 03.36^{\prime \prime} \mathrm{N}, 117^{\circ} 14^{\prime} 52.75^{\prime \prime} \mathrm{W}, 11$ May 2009 (SDNHM a000838); $1 \delta^{\star}$, same data except $32^{\circ} 41^{\prime} 28.99^{\prime \prime} \mathrm{N}$, $117^{\circ} 14^{\prime} 55.25^{\prime \prime} \mathrm{W}, 21$ December $^{2} 009$ (SDNHM a000834); 1 ठ․ same data except $32^{\circ} 39^{\prime} 34.27^{\prime \prime} \mathrm{N}, 117^{\circ} 14^{\prime} 36.67^{\prime \prime} \mathrm{W}, 18$ February 2010 (SDNHM a000875); 2 $\delta$, same data except $32^{\circ} 42^{\prime} 35.45^{\prime \prime} \mathrm{N}, 117^{\circ} 15^{\prime} 08.8^{\prime \prime} \mathrm{W}, 13$ July 2009 (SDNHM a000869); 2 o, same data except $32^{\circ} 41^{\prime} 45.74^{\prime \prime} \mathrm{N}$, $117^{\circ} 14^{\prime} 36.24^{\prime \prime} \mathrm{W}, 18$ February 2010 (SDNHM a000857); $1 \delta^{\top}$, same data except $32^{\circ} 39^{\prime} 34.42^{\prime \prime} \mathrm{N}, 117^{\circ} 14^{\prime} 36.38^{\prime \prime} \mathrm{W}$ (SDNHM a000863); $1 \delta^{\circ}$, same data except $32^{\circ} 41^{\prime} 50.39^{\prime \prime} \mathrm{N}$, $117^{\circ} 14^{\prime} 42.43^{\prime \prime} \mathrm{W}, 11$ May 2009 (SDNHM a000865).

Etymology.-The specific name is a noun in apposition taken from the type locality.

Diagnosis.-Males of this species differ from C. quintin by having the ventral notch of the conductor shallower and narrower (Fig. 20a); and by the embolus, which has less pronounced curves (Fig. 19c). Females differ from C. quintin by having copulatory openings, which are less conspicuous (Fig. 20c); and by the primary spermathecae, which have two pronounced curves (Fig. 19b).

Description.-Male (holotype): Coloration: Carapace yellow. Chelicerae brown. Condyles yellow. Endites yellow with white tips. Labium light brown with white tip. Sternum yellow with brown border. Legs yellow, tibia-metatarsus brown. Three rings on femur, one on patella, and two on tibia. Opisthosoma light brown, several dark brown spots, two pairs of anterior white spots, and a couple of white spots next to anal tubercle. Spinnerets yellow, basal segment of PLS with black borders.

Habitus: Total length 6.5. Carapace length 3.25, width 2.38, cephalic region width 1.21 , ocular region width 0.67 . Eye diameter: AME and PME 0.12, ALE and PLE 0.13. Distance between eyes: AME-AME 0.04, AME-ALE 0.04, AME-PME 0.13, ALE-PLE 0.04, ALE-ALE 0.29, PME-PME 0.1, PMEPLE 0.06. Clypeus height 0.17. Chelicerae: basal segment length 1.12 , fang length 0.61 . Labium wider than long $(0.45 /$ 0.3 ). Endites slightly convergent (distance at their base compared to their tips $0.45 / 0.3$ ). Sternum longer than wide (1.52/1.29). Opisthosoma longer than wide (3.38/1.88). ALS 
separated by more than their basal diameter $(0.27 / 0.23)$, PLS with distal segment as long as basal segment $(0.42 / 0.42)$.

Legs: Length: I- femur 2.88/ patella-tibia 3.38/ metatarsus 2.5/ tarsus 2; II- 2.75/3.38/2.63/ 1.88; III- 3/ 3.25/3.25/ 1.75; IV- $3.63 / 4.38 / 4.5 / 2.25$.

Spination: Femur dorsal I- 1-2-2/ II- 1-3-2/ III- 1-3-2/ IV- 11-2; patella I- dorsal $1-1 /$ prolateral $1 /$ retrolateral 0 ; II- 1-1/ 1 / 0 ; III- 1-1/ 1/ 1; IV- 1-1/ 1/ 1; tibia I- dorsal 0/ ventral 1-2-1-2/ prolateral 0-1-2/ retrolateral 0; II- 1-1-0/ 1-2-2/ 1-1-0/0; III- 1$1-0 / 1-1-2 /$ 1-1-0/ 1-1-0; IV- 1-1-0/ 1-2-2/ 1-1-0/ 1-1-0; metatarsus I- $0 / 2-2-2 / 1-0-1 / 0$; II- 0-0-1/ 2-2-2/ 0-1-1/ 0-1-1; III- 2-1-2/ 2-2-2/ 0-1-1/ 0-1-1; IV- 3-1-2/ 1-1-1-2-2/ 0-1-1/ 0-11. Number of trichobothria on tarsus: I- 5, II- 5, III- 5, IV- 5 .

Pedipalp: Number of dorsal spines: femur 2, tibia 4 . Cymbium length 1.03 , width 0.55 . Embolus sinuous no exceeding distally the conductor ventral notch. The notch extends half the conductor length (Figs. 19a, c, e, 20a, b).

Female (paratype) (CASENT 9048908): Coloration: Carapace yellow, black spot between AME. Chelicerae and condyles brown. Endites and labium light brown with white tips. Sternum yellow with three pairs of brown spots. Femur yellow, patella-tarsus brown. Opisthosoma light brown with anterior brown spot, yellow foliage, and lateral brown spots. Spinnerets yellow, basal segment of PLS with black borders.

Habitus: Total length 7.88. Carapace length 3.13 , width 1.88 , cephalic region width 1.12 , ocular region width 0.61 . Eye diameter: AME and PME 0.12, ALE and PLE 0.15. Distance between eyes: AME-AME 0.04, AME-ALE 0.04, AME-PME 0.17, ALE-PLE 0.04, ALE-ALE 0.29, PME-PME 0.08, PMEPLE 0.1. Clypeus height 0.17. Chelicerae: basal segment length 1.29 , fang length 0.67 . Labium wider than long $(0.45 / 0.36)$. Endites slightly convergent (distance at their base compared to their tips $0.45 / 0.3)$. Sternum longer than wide $(1.57 / 1.19)$. Opisthosoma longer than wide (4.5/2.5). ALS separated by their basal diameter $(0.27 / 0.27)$, PLS with distal segment slightly longer than basal segment $(0.52 / 0.48)$.

Legs: Length: I- femur 2.38/ patella-tibia 2.85/ metatarsus $2 / \operatorname{tarsus} 1.54$; II- 2.23/ 2.54/ 2/ 1.46; III- 2.31/ 2.69/ 2.31/ 1.38; IV- $2.85 / 3.54 / 3.08 / 1.62$.

Spination: Femur dorsal I- 1-2-2/ II- 1-3-2/ III- 1-3-2/ IV- 12-2; patella I- dorsal 1-1/ prolateral $1 /$ retrolateral 0; II- 1-1/ 1 / 0 ; III- 1-1/ 1/ 1; IV- 1-1/ 1/ 1; tibia I- dorsal 0/ ventral 2-2-2/ prolateral 1-1-0/ retrolateral 0; II- 0/ 2-2-2/ 1-1-0/ 0; III- 1-1-0/ 1-1-2/ 1-1-0/ 1-1-0; IV-1-1-0/ 1-1-2/ 1-1-0/ 1-1-0; metatarsus I$0 / 2-2-2 / 0-1-1 / 0$; II- 0-0-1/ 2-2-2/ 0-1-1/ 0-0-1; III- 2-1-2/ 2-2$2 / 0-1-1 / 0-1-1$; IV- 3-1-2/ 1-1-1-2-2/ 0-1-1/ 0-1-1. Number of trichobothria on tarsus: I- 5, II- 5, III- 5, IV- 6.

Pedipalp: Dorsal spines on femur: 2. Prolateral spines on tibia: $1-2$.

Epigynum: Plate length 0.52 , width 0.82 . Copulatory openings separated by their width. Copulatory ducts as sclerotized as spermathecae. Primary spermathecae with two pronounced curves, one at anterior part where the copulatory ducts are connected, and one at posterior part. Primary spermathecae separated by their width (Figs. 19b, d, f, 20c-e).

Variation.-Total body length in males varies between 4.38 and $6.5(n=10)$ and in females between 5 and $7.88(n=10)$. Carapace length in males varies between 2.25 and $3.25(n=10)$ and in females between 2.63 and $3.38(n=10)$. Patella-tibia I length in males varies between 2.5 and $3.5(n=10)$ and in females between 2.25 and $3(n=10)$.

Distribution.-California (USA) and Baja California (Mexico) (Fig. 23a).

\section{Lagunella Maya-Morales \& Jiménez gen. nov. http://zoobank.org/?lsid=urn:lsid:zoobank. org:act:F45F3431-312D-4ED5-8A3C-EC6DC3398752}

Type species.-Lagunella guaycura sp. nov.

Etymology.-The generic name is derived from the Biosphere Reserve Sierra La Laguna, which is unique because it has the largest pine-oak forest on the BCP. The gender is feminine.

Diagnosis.-Lagunella gen. nov. is diagnosed by the following characters in combination: male pedipalp with a whip-shaped embolus originating on the basal part of the tegulum (Fig. 21c); conductor with two projections (Fig. 22b); tegulum with ventral part mostly membranous; tegular median process sclerotized (Fig. 22a); and RTA with distal and dorsal projections (Fig. 21e). Epigynum with atrium wider than long; copulatory openings in lateral position; anterolateral hyaline spurs present (Fig. 22c); copulatory ducts long tubes surrounding the primary spermathecae dorsally (Fig. 22d); primary spermathecae longer than wide and curved (Fig. $21 \mathrm{~b}$ ); secondary spermathecae in short and rounded diverticula (Fig. 21f) at the junction of the copulatory ducts and the primary spermathecae (Fig. 21d); and fertilization ducts short (Fig. 22d).

Lagunella gen. nov. differs from Eratigena and Tegenaria by having strongly procurved eye rows in frontal view. It differs from Agelenopsis, Barronopsis, Melpomene and Tortolena by the absence of a tegular lateral process; from Calilena by the absence of both a fulcrum on the male pedipalp and a scape on the epigynum; from Hololena by having the embolus supported by the conductor only and by the shape of the primary spermathecae, which are longer than wide; from Rualena by the absence of both a membranous fulcrum and a posterior ridge on the posterior margin of the epigynal atrium; from Rothilena by having two projections on the conductor and no hoods on the epigynal atrium; from Callidalena gen. nov. by having the embolus originating from the basal part of tegulum and by the shape of the epigynal atrium, which has as a deep posterior cavity; and from Bajacalilena gen. nov. by having the embolus with a simple curve and the primary spermathecae longer than wide. Lagunella gen. nov. also differs from Calilena, Hololena, Rualena, Rothilena, Callidalena gen. nov. and Bajacalilena gen. nov. by having three to four retromarginal teeth on the chelicerae. Males of Lagunella gen. nov. differ from Hoffmannilena, Novalena, and Cabolena gen. nov. by having the embolus originating from the basal part of the tegulum and the RTA on the distal part of the tibia. Females of Lagunella gen. nov. differ from Hoffmannilena by the absence of a strongly sclerotized epigynal plate, and from Novalena and Cabolena gen. nov. by having the copulatory ducts of the epigynum connected anteriorly to the primary spermathecae.

Description.-Medium-sized spiders, 6-12 $\mathrm{mm}$ total length. Both eye rows strongly procurved in frontal view. Carapace with two longitudinal symmetrical dark bands intensified by feathery scale-like setae, a black band around the border of 
thoracic region, and a clear median band wider on cephalic region. Chelicerae with three promarginal teeth and three to four retromarginal teeth. Sternum longer than wide. Pedipalp femur with three dorsal spines. Legs with spines, longer in males than in females. Leg IV the longest. Rings present on femur, patella and tibia. Patella-tibia I shorter than carapace. Patella I and II with two dorsal spines and one prolateral spine, patella III and VI with two dorsal spines, one prolateral spine, and one retrolateral spine. Leg tarsi with seven to nine trichobothria. Capsulate tarsal organ in distal position of trichobothrial row. Opisthosoma oval with dorsal foliate pattern and/or posterior chevrons. Colulus divided, represented by few hairs. PLS longest with distal segment usually as long as basal. Embolus a long whip originating on basal part of tegulum (Fig. 21a). Conductor with ventral and dorsal projections of similar size. Membranous part covering twothirds the ventral surface of tegulum (Fig. 22a). Tegular median process present (Fig. 21a). RTA on distal part of tibia and with distal and dorsal projections (Fig. 22b). Dorsal projection with one spine. Epigynal plate and atrium wider than long. Copulatory openings in lateral position. Anterolateral hyaline spurs present (Fig. 22c). Copulatory ducts long and surrounding dorsally the primary spermathecae and connected anteriorly (Fig 21b). Primary spermathecae longer than wide and curved (Fig. 22d). Secondary spermathecae in short and rounded diverticula on union of copulatory ducts and primary spermathecae (Fig. 21d). Fertilization ducts short (Fig. 22d).

Distribution.-Lagunella gen. nov. is distributed in Mexico in the State of Baja California Sur (Fig. 23b).

Included taxa.- One species: L. guaycura sp. nov.

\section{Lagunella guaycura Maya-Morales, Jiménez \& Palacios- Cardiel sp. nov. \\ http://zoobank.org/?lsid=urn:lsid:zoobank. org:act:D9FBAD42-9823-4EC6-B6E8-5D287860AC5E}

(Figs. 21, 22, 23b)

Type material.-Holotype male: Municipality of La Paz, Biosphere Reserve Sierra La Laguna, La Cieneguita, Baja California Sur, Mexico, $23^{\circ} 33^{\prime} 02^{\prime \prime} \mathrm{N}, 109^{\circ} 56^{\prime} 26.8^{\prime \prime} \mathrm{W}, 1758 \mathrm{~m}$, 7 October 2011, C. Palacios, J. Maya \& J. Villarreal (CARCIB 3749). Paratypes: MEXICO: Baja California Sur: 1 ô, same data as holotype (CARCIB 1887); 1 , same data as holotype (CARCIB 1911); 4 o, 4 , same data as holotype (CARCIB 1912); 1 , same data as holotype (CARCIB 3749); 1 , same data as holotype except Valle La Laguna, $1630 \mathrm{~m}, 29$ September 1987, A. Cota \& M.L. Jiménez (CARCIB 54); 1 $\delta$, same data as holotype except Cañón La Burrera, Arroyo La Palma, 11 December 1986, A. Acevedo (CARCIB 24); 1 \%, same data except 19 April 1988, M.L. Jiménez (CARCIB 1859); 1 \&, same data as holotype except Cañón La Zorra, 1640 m, 4 November 1986, F. \& A. Cota (CARCIB 48); 1 ơ, same data except 12 February 1988, M.L. Jiménez (CARCIB 1863); 2 \&, same data as holotype except Las Cascadas, $23^{\circ} 33^{\prime} 56.9^{\prime \prime} \mathrm{N}, 109^{\circ} 58^{\prime} 07.6^{\prime \prime} \mathrm{W}, 1734 \mathrm{~m}$, hand collecting on ground, 8 October 2011 (CARCIB 1880); 1 o, same data as holotype except road to La Palma, $23^{\circ} 33^{\prime} 22.6^{\prime \prime} \mathrm{N}$, $109^{\circ} 58^{\prime} 43.9^{\prime \prime} \mathrm{W}, 1818 \mathrm{~m}$, hand collecting on ground, 5 October 2011 (CARCIB 1889); 1 , same data (CARCIB 1913); 4 ơ, 1 ๆ, same data (CARCIB 1914); 1 $\delta$, same data as holotype except La Ventana, 21 April 1988, M.L. Jiménez (CARCIB 3746); 1 \&, same data (CARCIB 3748); 1 o, same data as holotype except Valle La Laguna, 21 September 1987, F. Cota (CARCIB 3747); 1 o, same locality as holotype, 4 December 1944, M. Correa (AMNH).

Other material examined.-MEXICO: Baja California Sur: 2 ㅇ, same data as holotype except Cañón La Zorra, 1640 m, 1 November 1984, M.L. Jiménez (CARCIB 4); 5 \%, same data except 25 February 1987, M. Acevedo \& M.L. Jiménez (CARCIB 19); 9 \%, same data (CARCIB 39); 1 , same data except 19 August 1986, F. Cota \& M.L. Jiménez (CARCIB 34); 7 ô, same data (CARCIB 42); 1 \%, same data except 28 September 1986, A. \& F. Cota (CARCIB 43); 1 의 same data except date unknown, M.L. Jiménez \& A. Cota (CARCIB 51); 3 ऊ, same data except 13 January 1988, M.L. Jiménez (CARCIB 1864); 3 , same data as holotype except Valle La Laguna, 1830 m, 20 April 1988, M.L. Jiménez \& R. Domínguez (CARCIB 27); 7 , same data except $1630 \mathrm{~m}$, 29 September 1987, A. Cota \& M.L. Jiménez (CARCIB 28); 8 , same data except 4 June 1988, A. Cota (CARCIB 50); 5 , same data except 16 January 1988, V. Roth \& M.L. Jiménez (CARCIB 1851); 3 ơ, same data except 27 September 1987, F. Cota (CARCIB 1854); 1 , same data as holotype except road to La Laguna, $23^{\circ} 33^{\prime} 06.8^{\prime \prime} \mathrm{N}, 109^{\circ} 59^{\prime} 03.9^{\prime \prime} \mathrm{W}, 1757 \mathrm{~m}$, night collecting, 7 October 2011, C. Palacios, J. Maya \& J. Villarreal (CARCIB 1875); 8 o, same data as holotype except La Cieneguita, 20 April 1988, M.L. Jiménez \& S. Guzmán (CARCIB 40); 1 \&, same data except 19 April 1988, M.L. Jiménez (CARCIB 1848); 1 \&, same data as holotype except La Ventana, 21 April 1988, M.L. Jiménez (CARCIB 1858); 1 o, same locality as holotype, 12 December 1986, A. Cota (CARCIB 1861); 1 ô, same data as holotype except Paso La Golondrina, 1640 m, 13 January 1988, V. Roth (CARCIB 1865); 1 , same data as holotype except Arroyo La Palma, $23^{\circ} 34^{\prime} 24.8^{\prime \prime} \mathrm{N}, 109^{\circ} 58^{\prime} 27^{\prime \prime} \mathrm{W}, 1798 \mathrm{~m}$, hand collecting on ground, 6 October 2011, C. Palacios, J. Maya \& J. Villarreal (CARCIB 1882); 4 ô, 3 क , same data (CARCIB 3826); 1 ô, same data except beat sheet, A. Orozco (CARCIB 1891); 1 , same data except $23^{\circ} 33^{\prime} 22.6^{\prime \prime} \mathrm{N}, 109^{\circ} 58^{\prime} 43.5^{\prime \prime} \mathrm{W}, 1818 \mathrm{~m}, 5$ October 2011, C. Palacios, J. Maya \& J. Villarreal (CARCIB 1885); 1 đo, same data as holotype except Las Cascadas, $23^{\circ} 32^{\prime} 57.7^{\prime \prime} \mathrm{N}, 109^{\circ} 58^{\prime} 06.2^{\prime \prime} \mathrm{W}, 1739 \mathrm{~m}$, beat sheet, 8 October 2011, C. Palacios, J. Maya \& J. Villarreal (CARCIB 1892).

Etymology.-The specific name is a noun in apposition and refers to the now extinct native tribe "Guaycura" that occupied the southern part of the BCP.

Diagnosis. - By the characters of the genus.

Description.-Male (holotype): Coloration: Carapace yellow with white feathery scale-like setae. Chelicerae and condyles brown. Endites yellow with white tips. Labium light brown with white tip. Sternum orange with a diffuse pattern of black spots. Femur yellow, patella and tarsus orange, metatarsus brown. Three rings on femur, black spots on metatarsus. Opisthosoma reddish with lateral black bands, four arrowhead shaped spots. Spinnerets orange, PLS with basal segment black.

Habitus: Total length 7.25. Carapace length 4, width 2.38, cephalic region width 1.27 , ocular region width 0.7 . Eye diameter: AME 0.12, ALE 0.19, PME 0.15, PLE 0.13. Distance between eyes: AME-AME 0.06, AME-ALE 0.04, AME-PME 0.13, ALE-PLE 0.04, ALE-ALE 0.29, PME-PME 
0.08, PME-PLE 0.12. Clypeus height 0.23. Chelicerae with four retromarginal teeth; basal segment length 1.36 , fang length 0.58 . Labium slightly wider than long $(0.52 / 0.48)$. Endites slightly convergent (distance at their base compared to their tips $0.52 / 0.24)$. Sternum longer than wide (1.9/1.38). Opisthosoma longer than wide (3.75/2). ALS separated by less than their basal diameter $(0.13 / 0.25)$, PLS with distal segment slightly shorter than basal segment $(0.42 / 0.44)$.

Legs: Length: I- femur $2.63 /$ patella-tibia $3.25 /$ metatarsus 2.38/ tarsus 1.75; II- 2.5/3.13/ 2.5/ 1.63; III- 3.13/3.38/ 2.88/ 1.5; IV- 3.13/4/3.75/ 1.75 .

Spination: Femur dorsal I- 1-2-3/ II- 1-3-3/ III- 1-3-3/ IV- 12-2; patella I- dorsal 1-1/ prolateral 1/ retrolateral 0; II- 1-1/ 1/ 0 ; III- 1-1/ 1/ 1; IV-1-1/ 1/ 1; tibia I- dorsal 0/ ventral 2-2-2-2/ prolateral 1-1-0/ retrolateral 0 ; II- 0/ 1-2-2/ 1-1-0/ 0; III- 1-1-0/ 2-2-2/ 1-1-0/ 1-1-0; IV- 1-2-0/ 1-1-2-2/ 1-1-0/ 1-1-1; metatarsus I- $0 / 2-2-2 / 0-1-1 / 0$; II- $0 / 2-2-2 / 0-1-1 / 0$; III- 3-2-2/ 1-2-2/ 0-01/ 0-0-1; IV- 6-0-2/ 2-2-2/ 1-1-1/ 0-0-1. Number of trichobothria on tarsus: I- 8, II- 7, III- 9, IV- 7.

Pedipalp: Number of dorsal spines: femur 3, tibia 7 . Cymbium length 1.12, width 0.58 .

Female (paratype from holotype locality) (CARCIB 3749): Coloration: Carapace yellow. Chelicerae dark brown and condyles orange. Endites and labium orange with white tips. Sternum brown with a central yellow band. Femur-patella yellow, tibia-metatarsus brown, tarsus light brown. Opisthosoma as in male but with five arrowhead shaped spots. ALS orange, PLS with basal segment black, distal segment yellow.

Habitus: Total length 10.63. Carapace length 4.88, width 2.88 , cephalic region width 1.67 , ocular region width 0.88 . Eye diameter: AME and PME 0.19, ALE and PLE 0.21. Distance between eyes: AME-AME 0.04, AME-ALE 0.08, AME-PME 0.19, ALE-PLE 0.06, ALE-ALE 0.37, PME-PME 0.1, PMEPLE 0.15. Clypeus height 0.29 . Chelicerae with three retromarginal teeth; basal segment length 1.64, fang length 0.76 . Labium slightly wider than long $(0.57 / 0.52)$. Endites slightly convergent (distance at their base compared to their tips 0.57 / $0.43)$. Sternum longer than wide $(2.05 / 1.67)$. Opisthosoma longer than wide $(5 / 3.25)$. ALS separated by less than their basal diameter $(0.24 / 0.36)$, PLS with distal segment slightly longer than basal segment $(0.52 / 0.45)$.

Legs: Length: I- femur 3/ patella-tibia 3.88/metatarsus 2.5/ tarsus 1.88; II- 2.88/3.75/2.63/ 1.63; III- 2.75/3.75/3/ 1.5; IV$3.5 / 4.63 / 4.25 / 1.75$.

Spination: Femur dorsal I- 1-2-3/ II- 2-3-3/ III- 1-3-3/ IV- 12-3; patella I- dorsal 1-1/ prolateral $1 /$ retrolateral 0 ; II- $1-1 / 1 /$ 0; III- 1-1/ 1/ 1; IV- 1-1/ 1/ 1; tibia I- dorsal 0/ ventral 2-2-2/ prolateral 1-1-0/ retrolateral 0 ; II- 1-1-0/ 1-2-2/ 1-1-1/ 0; III- 12-1-0/ 2-2-2/ 0-1-0/ 0-0-1; IV- 1-2-1-0/ 1-2-2/ 1-1-0/ 0-1-0; metatarsus I- 0/ 2-1-2-2/ 0/ 0-0-1; II- 0/ 2-2-1/ 0-1-1/ 0-0-1; III$2-2-2 / 2-2-2 / 0-1-1 / 0-1-1$; IV- 2-1-2/ 1-1-1-1-2/ 0-1-1/ 1-0-1. Number of trichobothria on tarsus: I- 7, II- 7, III- 7, IV- 7.

Pedipalp: Dorsal spines on femur: 3. Prolateral spines on tibia: $1-2$.

Epigynum: Plate length 0.64 , width 0.94 .

Variation.- Total body length in males varies between 6.25 and $8.5(n=16)$ and in females between 7.88 and $11.25(n=$ 14). Carapace length in males varies between 3.5 and $4.25(n=$ 16) and in females between 3.38 and $5(n=14)$. Patella-tibia I length in males varies between 3.25 and $3.75(n=15)$ and in females between 3.13 and $4.38(n=14)$.

Distribution.-Baja California Sur (Mexico) (Fig. 23b).

\section{RESULTS}

Molecular data.-We obtained 48 COI sequences from 11 species of Ageleninae, including five of the seven new species described in this study that are found on the BCP and in California. Sequence lengths ranged from 632 to 647 bp. For each species, we obtained one to five unique haplotypes (Table 2), and all 28 haplotypes were used in the molecular analysis. Five haplotypes in a single species were found in Rothilena cochimi from three localities and three unique haplotypes in Cabolena kosatli sp. nov. from one locality (Table 3). High intraspecific pairwise sequence divergence was found in Bajacalilena clarki sp. nov. (2.2\%) while Rothilena cochimi and $R$. pilar showed the smallest interspecific divergence (1.4\%) (Table 3). Genetic divergences between genera ranged from $7.5 \%$ (between Cabolena gen. nov. and Lagunella gen. nov.) to $13.8 \%$ (between Bajacalilena gen. nov. and Calilena, and between Cabolena gen. nov. and Hololena). Bayesian phylogenetic analysis showed Bajacalilena gen. nov. and Rothilena as sister-taxa with a posterior probability of $99 \%$; this clade was sister to Callidalena gen. nov. with a posterior probability of $97 \%$ (Fig. 24). Hololena formed a monophyletic group with all three genera (posterior probability of $95 \%$ ). The other two new genera, Cabolena and Lagunella were sistertaxa with a posterior probability of $100 \%$ (Fig. 24).

\section{DISCUSSION}

In the Western Hemisphere, the subfamily Ageleninae is now composed of 17 genera: Agelenopsis, Barronopsis, Calilena, Eratigena, Hoffmannilena, Hololena, Melpomene, Neotegenaria, Novalena, Rothilena, Rualena, Tegenaria, Tortolena, and the four new genera proposed in this study. With the exception of Eratigena and Tegenaria, the genera are restricted to the Americas and their distribution is mostly limited to North and Central America.

Three of the four new genera are presumably endemic to the BCP and the fourth, Callidalena gen. nov., is also present in southern California (Fig. 23). The richness of agelenine genera on the BCP is greater in the northern part (State of Baja California) with the presence of North America genera such as Agelenopsis, Calilena, Hololena and Rualena. The richness of genera and species is lower in the central part of the BCP, with only Bajacalilena gen. nov. and Rualena (Maya-Morales \& Jiménez 2016). The number of species increases in the southern part of the BCP (State of Baja California Sur), where Rothilena, Cabolena gen. nov. and Lagunella gen. nov. are found. The last two genera are present in the Biosphere Reserve Sierra La Laguna above $1600 \mathrm{~m}$. Cabolena huiztocatl is also present along the Pacific coast (Fig. 23b).

At the genus level, we found substantial sequence divergence $(7.4-13.8 \%)$ among the seven genera analyzed in this study (Table 3). Comparison of these with other genera of agelenids from other regions of the world (data not shown here) further confirmed that the new genera described in this study are indeed distinct. However, genetic distance information showed two species of Cabolena gen. nov., Cabolena 
Table 2.- Haplotype data of included COI sequences of agelenids from the Baja California Peninsula and California.

\begin{tabular}{|c|c|c|c|}
\hline Species & Haplotype & No. & Locality \\
\hline Bajacalilena clarki & $\mathrm{Bc}-\mathrm{H} 1$ & $10^{2}$ & Mexico, Baja California Sur, SE. of Mesa El Tecolote, $26^{\circ} 59^{\prime} \mathrm{N}, 113^{\circ} 26^{\prime} \mathrm{W}$ \\
\hline \multirow[t]{2}{*}{ Bajacalilena clarki } & \multirow[t]{2}{*}{$\mathrm{Bc}-\mathrm{H} 2$} & 10 & Mexico, Baja California Sur, Arroyo San Lorenzo, $26^{\circ} 56^{\prime} \mathrm{N}, 113^{\circ} 47^{\prime} \mathrm{W}$ \\
\hline & & 19 & Mexico, Baja California, $9 \mathrm{~km} \mathrm{NW}$. of Rancho Santa Inés, $26^{\circ} 46^{\prime} \mathrm{N}, 114^{\circ} 46^{\prime} \mathrm{W}$ \\
\hline Bajacalilena clarki & $\mathrm{Bc}-\mathrm{H} 3$ & 10 & Mexico, Baja California, $11.7 \mathrm{~km}$ E. of El Rosario, $30^{\circ} 04^{\prime} 30^{\prime \prime} \mathrm{N}, 115^{\circ} 37^{\prime} 55^{\prime \prime} \mathrm{W}$ \\
\hline Cabolena huiztocatl & $\mathrm{Ch}-\mathrm{H} 1$ & $10^{\top}$ & Mexico, Baja California Sur, Sierra La Laguna, $23^{\circ} 33^{\prime} 22.6^{\prime \prime} \mathrm{N}, 109^{\circ} 58^{\prime} 43.5^{\prime \prime} \mathrm{W}$ \\
\hline Cabolena huiztocatl & $\mathrm{Ch}-\mathrm{H} 2$ & 1 우 & Mexico, Baja California Sur, Punta San Pedro, $23^{\circ} 23^{\prime} 22.4^{\prime \prime} \mathrm{N}, 110^{\circ} 12^{\prime} 30.2^{\prime \prime} \mathrm{W}$ \\
\hline Cabolena huiztocatl & $\mathrm{Ch}-\mathrm{H} 3$ & 29 & Mexico, Baja California Sur, Punta San Pedro, $23^{\circ} 23^{\prime} 22.4^{\prime \prime} \mathrm{N}, 110^{\circ} 12^{\prime} 30.2^{\prime \prime} \mathrm{W}$ \\
\hline Cabolena huiztocatl & $\mathrm{Ch}-\mathrm{H} 4$ & 19 & Mexico, Baja California Sur, Sierra La Laguna, $23^{\circ} 33^{\prime} 06.7^{\prime \prime} \mathrm{N}, 109^{\circ} 59^{\prime} 07.3^{\prime \prime} \mathrm{W}$ \\
\hline Cabolena kosatli & $\mathrm{Ck}-\mathrm{H} 1$ & 1 우 & Mexico, Baja California Sur, Sierra La Laguna, $23^{\circ} 33^{\prime} 06.8^{\prime \prime} \mathrm{N}, 109^{\circ} 59^{\prime} 03.9^{\prime \prime} \mathrm{W}$ \\
\hline Cabolena kosatli & $\mathrm{Ck}-\mathrm{H} 2$ & 10 & Mexico, Baja California Sur, Sierra La Laguna, $23^{\circ} 33^{\prime} 06.7^{\prime \prime} \mathrm{N}, 109^{\circ} 59^{\prime} 07.3^{\prime \prime} \mathrm{W}$ \\
\hline Cabolena kosatli & $\mathrm{Ck}-\mathrm{H} 3$ & 19 & Mexico, Baja California Sur, Sierra La Laguna, $23^{\circ} 33^{\prime} 22.6^{\prime \prime} \mathrm{N}, 109^{\circ} 58^{\prime} 43.5^{\prime \prime} \mathrm{W}$ \\
\hline Cabolena sotol & Cs-H1 & 29 & Mexico, Baja California Sur, Sierra La Laguna, $23^{\circ} 33^{\prime} 22.6^{\prime \prime} \mathrm{N}, 109^{\circ} 58^{\prime} 43.5^{\prime \prime} \mathrm{W}$ \\
\hline Calilena angelena & $\mathrm{Ca}-\mathrm{H} 1$ & 19 & Mexico, Baja California, Highway Ensenada-Tijuana km 14, $31^{\circ} 54^{\prime} 24^{\prime \prime} \mathrm{N}, 116^{\circ} 43^{\prime} 59^{\prime \prime} \mathrm{W}$ \\
\hline Calilena angelena & $\mathrm{Ca}-\mathrm{H} 2$ & 10 & Mexico, Baja California, $8 \mathrm{~km} \mathrm{NW}$. of Santo Tomás, $31^{\circ} 37^{\prime} \mathrm{N}, 116^{\circ} 27^{\prime} \mathrm{W}$ \\
\hline Calilena angelena & $\mathrm{Ca}-\mathrm{H} 3$ & $20^{2}, 19$ & Mexico, Baja California, $8 \mathrm{~km} \mathrm{NW}$. of Santo Tomás, $31^{\circ} 37^{\prime} \mathrm{N}, 116^{\circ} 27^{\prime} \mathrm{W}$ \\
\hline Callidalena tijuana & $\mathrm{Ct}-\mathrm{H} 1$ & 10 & USA, California, San Diego, Naval Base Point Loma, $32^{\circ} 41^{\prime} 28.22^{\prime \prime} \mathrm{N}, 117^{\circ} 14^{\prime} 55.09^{\prime \prime} \mathrm{W}$ \\
\hline Callidalena tijuana & $\mathrm{Ct}-\mathrm{H} 2$ & $3 \sigma^{\circ}, 3 q$ & USA, California, San Diego, Naval Base Point Loma \\
\hline Hololena septata & $\mathrm{Hs}-\mathrm{H} 1$ & $10^{5}$ & USA, California, San Diego, Naval Base Point Loma, $32^{\circ} 42^{\prime} 44.06^{\prime \prime} \mathrm{N}, 117^{\circ} 15^{\prime} 09.04^{\prime \prime} \mathrm{W}$ \\
\hline Hololena septata & $\mathrm{Hs}-\mathrm{H} 2$ & $10^{*}$ & USA, California, Lemon Grove \\
\hline Hololena septata & $\mathrm{Hs}-\mathrm{H} 3$ & 19 & USA, California, Balboa Park East \\
\hline Lagunella guaycura & $\mathrm{Lg}-\mathrm{H} 1$ & $4 \delta^{\circ}, 5 q$ & Mexico, Baja California Sur, Sierra La Laguna \\
\hline Rothilena cochimi & Rc-H1 & 19 & Mexico, Baja California Sur, San José de Comondú, $23^{\circ} 06^{\prime} 34^{\prime \prime} \mathrm{N}, 111^{\circ} 49^{\prime} 13^{\prime \prime} \mathrm{W}$ \\
\hline Rothilena cochimi & $\mathrm{Rc}-\mathrm{H} 2$ & 10 & Mexico, Baja California Sur, San Javier, $25^{\circ} 52^{\prime} 16.4^{\prime \prime} \mathrm{N}, 111^{\circ} 32^{\prime} 46.4^{\prime \prime} \mathrm{W}$ \\
\hline Rothilena cochimi & $\mathrm{Rc}-\mathrm{H} 3$ & 1 oे & Mexico, Baja California Sur, San Javier, $25^{\circ} 52^{\prime} 16.4^{\prime \prime} \mathrm{N}, 111^{\circ} 32^{\prime} 46.4^{\prime \prime} \mathrm{W}$ \\
\hline Rothilena cochimi & $\mathrm{Rc}-\mathrm{H} 4$ & $1 \sigma^{5}$ & Mexico, Baja California Sur, San Javier, $25^{\circ} 52^{\prime} 16.4^{\prime \prime} \mathrm{N}, 111^{\circ} 32^{\prime} 46.4^{\prime \prime} \mathrm{W}$ \\
\hline Rothilena cochimi & Rc-H5 & 19 & Mexico, Baja California Sur, Cuevas Pintas, $25^{\circ} 58^{\prime} 41.4^{\prime \prime} \mathrm{N}, 111^{\circ} 27^{\prime} 54.6^{\prime \prime} \mathrm{W}$ \\
\hline \multirow[t]{2}{*}{ Rothilena pilar } & \multirow[t]{2}{*}{$\mathrm{Rp}-\mathrm{H} 1$} & 19 & Mexico, Baja California Sur, El Pilar, $24^{\circ} 28^{\prime} 19.9^{\prime \prime} \mathrm{N}, 111^{\circ} 00^{\prime} 10.2^{\prime \prime} \mathrm{W}$ \\
\hline & & $2 \sigma^{*}$ & Mexico, Baja California Sur, Rancho El Camarón, $24^{\circ} 19^{\prime} 11.6^{\prime \prime} \mathrm{N}, 110^{\circ} 40^{\prime} 06.9^{\prime \prime} \mathrm{W}$ \\
\hline Rothilena pilar & $\mathrm{Rp}-\mathrm{H} 2$ & 19 & Mexico, Baja California Sur, Rancho El Camarón, $24^{\circ} 19^{\prime} 11.6^{\prime \prime} \mathrm{N}, 110^{\circ} 40^{\prime} 06.9^{\prime \prime} \mathrm{W}$ \\
\hline Rothilena sudcaliforniensis & Rs-H1 & 19 & Mexico, Baja California Sur, Sierra Las Cacachilas, $23^{\circ} 48^{\prime} 15.7^{\prime \prime} \mathrm{N}, 110^{\circ} 06^{\prime} 43.7^{\prime \prime} \mathrm{W}$ \\
\hline
\end{tabular}

huiztocatl sp. nov. and C. kosatli sp. nov. closer to Lagunella guaycura sp. nov. ( $7.8 \%$ and $7.5 \%$ variation, respectively) compared to the congeneric species $C$. sotol sp. nov. $(9.8 \%$ and $9.1 \%$ variation, respectively). Because of the genetic distances and the same distribution of Cabolena gen. nov. and Lagunella gen. nov., these two taxa could be considered as only one genus with high variability. According to Griswold (2001), some genera are necessarily monotypic because they are the sister groups of well defined clades with multiple species, and to define genera more broadly to eliminate monotypy would mean that these more inclusive groups become extremely difficult to diagnose (Griswold 2001). In this case, Lagunella gen. nov. and Cabonela gen. nov. have morphological characters that are useful for diagnosing them as separate genera (see above). Even though Lagunella gen. nov. appears to be monotypic, we think that the two groups will form separate clades when more species of Lagunella gen. nov. are discovered and included in the analysis.

Among the 11 species we studied, except for the three species from the genus Rothilena, all showed inter-specific genetic divergences greater than $3 \%$. The ABGD analysis also showed evidence for nine groups (species) instead of 11 . Bajacalilena clarki sp. nov., Calilena angelena, Callidalena tijuana sp. nov., Cabolena huiztocatl sp. nov., Cabolena kosatli

Table 3.- Kimura 2-parameter distance matrix for mitochondrial COI gene among 11 species of Agelenidae from the Baja California Peninsula and California. Distances within species in diagonal.

\begin{tabular}{|c|c|c|c|c|c|c|c|c|c|c|c|c|}
\hline & Species & 1 & 2 & 3 & 4 & 5 & 6 & 7 & 8 & 9 & 10 & 11 \\
\hline 1 & Bajacalilena clarki & 0.022 & & & & & & & & & & \\
\hline 2 & Cabolena huiztocatl & 0.127 & 0.004 & & & & & & & & & \\
\hline 3 & Cabolena kosatli & 0.120 & 0.061 & 0.009 & & & & & & & & \\
\hline 4 & Cabolena sotol & 0.141 & 0.098 & 0.091 & - & & & & & & & \\
\hline 5 & Calilena angelena & 0.138 & 0.118 & 0.113 & 0.126 & 0.010 & & & & & & \\
\hline 6 & Callidalena tijuana & 0.112 & 0.136 & 0.127 & 0.137 & 0.132 & 0.002 & & & & & \\
\hline 7 & Hololena septata & 0.115 & 0.122 & 0.108 & 0.138 & 0.105 & 0.115 & 0.004 & & & & \\
\hline 8 & Lagunella guaycura & 0.123 & 0.078 & 0.075 & 0.099 & 0.113 & 0.116 & 0.125 & - & & & \\
\hline 9 & Rothilena cochimi & 0.089 & 0.134 & 0.129 & 0.142 & 0.137 & 0.104 & 0.125 & 0.114 & 0.004 & & \\
\hline 10 & Rothilena pilar & 0.091 & 0.129 & 0.126 & 0.137 & 0.131 & 0.103 & 0.121 & 0.106 & 0.014 & 0.002 & \\
\hline 11 & Rothilena sudcaliforniensis & 0.084 & 0.137 & 0.123 & 0.144 & 0.136 & 0.106 & 0.126 & 0.115 & 0.024 & 0.025 & - \\
\hline
\end{tabular}




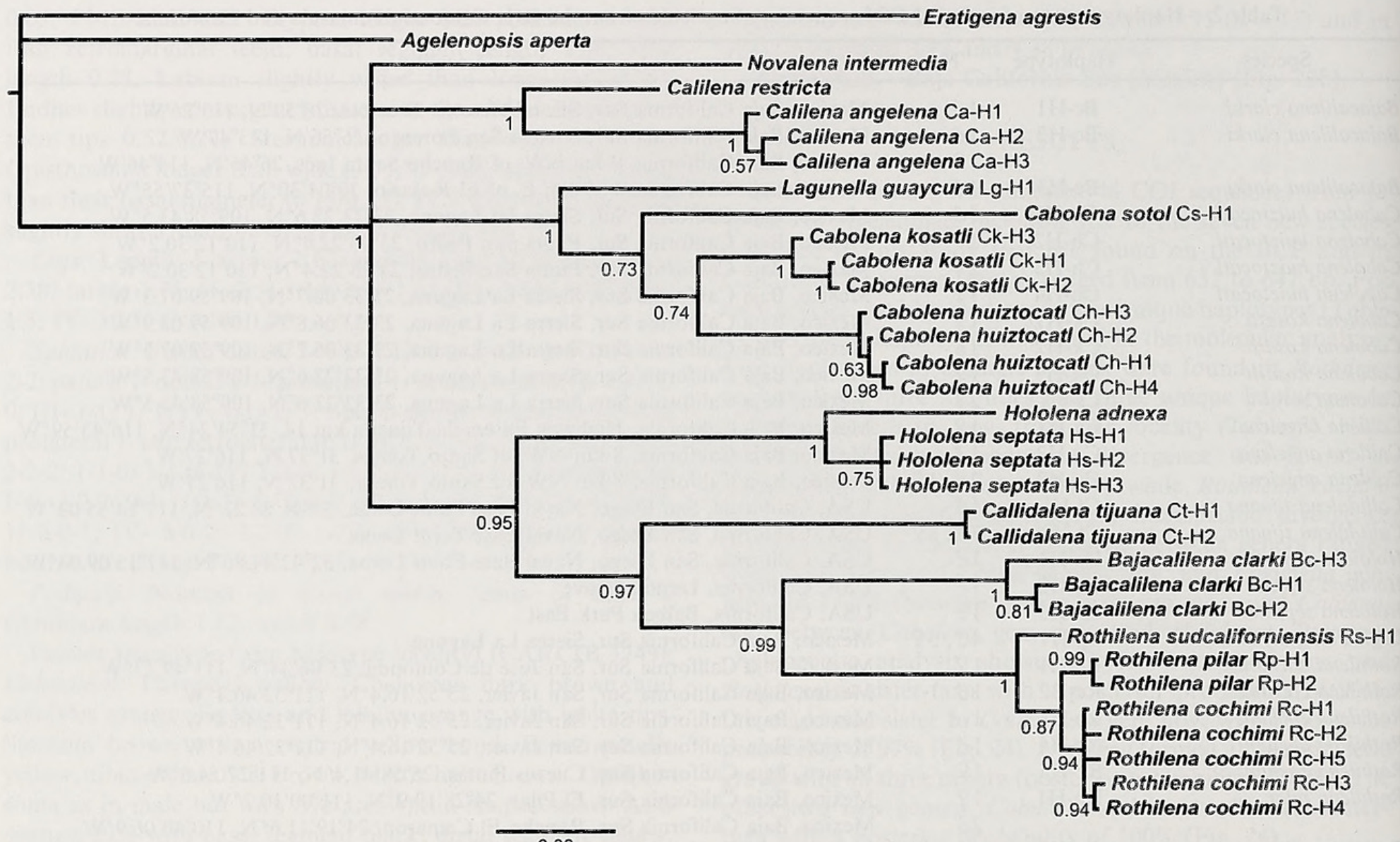

Figure 24.-Phylogenetic tree of sequenced Agelenidae, based on Bayesian analysis of cytochrome c oxidase subunit I (COI). Species names are followed by their haplotype information. Numbers at the nodes represent posterior probabilities.

sp. nov., Cabolena sotol sp. nov., Hololena septata, and Lagunella guaycura sp. nov. were recovered as different species. Yet the group composed of Rothilena cochimi, $R$. pilar and $R$. sudcaliforniensis showed genetic divergences of $1.1-2.5 \%$. However, there is some evidence showing inconsistencies between morphological and molecular data, including: (a) species are not discernible on the basis of mtDNA sequences according to a barcode gap; (b) species do not form distinguishable molecular clades; and (c) specimens from different species present a continuum of genital morphologies that may represent a single and highly variable species (Paquin \& Hedin 2004; Bolzern et al. 2013). According to genetic distances, the species of Rothilena are not discernible, suggesting that COI may not be a suitable gene to separate these species, compared to other agelenids (Croucher et al. 2004). It is also possible that congeneric species, showing low genetic divergence, can be attributed to their recent origin (Heber et al. 2003). Nonetheless, the Bayesian analysis showed the three species as three different groups ( $R$. sudcaliforniensis is only represented by one sequence) (Fig. 24), and morphologically, the three species are recognized by the particular shape of the conductor and the RTA in the male pedipalp and the shape of the hoods on the epigynum. It is important to note that, although the distribution of the genus is limited (Maya-Morales \& Jiménez 2013: fig. 7), we have not found more than one species of Rothilena in each locality.
The phylogenetic tree showed that Bajacalilena gen. nov., Rothilena and Callidalena gen. nov. are likely closely related. Also, Cabolena gen. nov. and Lagunella gen. nov. were grouped together as sister-taxa (Fig. 24). The first clade (Bajacalilena gen. nov., Callidalena gen. nov. and Rothilena) is distributed in arid habitats (desert shrubland and deciduous lowland forest). The second clade (Cabolena gen. nov. and Lagunella gen. nov.) is present in the higher pine-oak forest. Similar relationships were observed with maximum likelihood tree analysis, using PhyML software (Guindon et al. 2010) with nearest neighbor interchange and subtree pruning and a regrafting tree search option with 5,000 pseudoreplicates (not shown here). While the use of multiple genes is the most effective method for studying phylogenetic relationships, the geographic distribution of the genera and the analysis of a COI gene fragment nonetheless indicate a relationship with the vicariant events hypothesized for the BCP (Riddle et al. 2000; Crews \& Hedin 2006). The agelenids of the BCP are thus a useful group of spiders and an interesting model for future studies on the biogeography and evolution of the biota of this region.

\section{ACKNOWLEDGMENTS}

We are grateful to the following curators for the loan of specimens: Charles E. Griswold (CAS), Norman I. Platnick 
(AMNH), Michael A. Wall (SDNHM) and William H. Clark (OJSMNH and CICESE). We thank Sergio T. Álvarez Castañeda (CIBNOR) and project CONACYT (Consejo Nacional de Ciencia y Tecnología) 151189 for financial and logistic support to obtain DNA sequences. Griselda Gallegos Simental (CIBNOR) provided technical support for DNA extraction and amplification. Ariel Cruz Villacorta (CIBNOR) helped with SEM micrographs. Thanks to Jim Berrian (SDNHM), Darrell Ubick (CAS) and Louis N. Sorkin $(\mathrm{AMNH})$ for their assistance. Jaramar Villarreal and Diego Vega helped with the fieldwork. Ira Fogel at CIBNOR provided editorial suggestions and improvements. Special thanks to editor Michael Rix, Angelo Bolzern, and the anonymous reviewer for their recommendations and corrections to improve this manuscript. J.M.M. was a recipient of a graduate fellowship (CONACYT 213390). Specimens from CARCIB (2011-2015) were collected with scientific collector permits (SGPA/DGVS/08885/11, SGPA/DGVS/11311/12, DG/871/14 and SGPA/DGVS/09769/15) from SEMARNAT (Secretaría de Medio Ambiente y Recursos Naturales) to M.L.J.

\section{LITERATURE CITED}

Álvarez-Padilla, F. \& G. Hormiga. 2007. A protocol for digesting internal soft tissues and mounting spiders for scanning electron microscopy. Journal of Arachnology 35:538-542.

Ayoub, N.A. \& S.E. Riechert. 2004. Molecular evidence for Pleistocene glacial cycles driving diversification of a North America desert spider, Agelenopsis aperta. Molecular Ecology 13:3453-3465

Ayoub, N.A., S.E Riechert \& R.L. Small. 2005. Speciation history of the North American funnel web spiders, Agelenopsis (Araneae: Agelenidae): phylogenetic inferences at the population-species interface. Molecular Phylogenetics and Evolution 36:42-57.

Banks, N. 1898 Arachnida from Baja California and other parts of Mexico. Proceedings of the California Academy of Sciences 1:205308.

Becker, E., S. Riechert \& F. Singer. 2005. Male induction of female quiescence/catalepsis during courtship in the spider, Agelenopsis aperta. Behaviour 142:57-70.

Blagoev, G.A, J.R. Dewaard, S. Ratnasingham, S.L. Dewaard, L. Lu, J. Robertson et al. 2016. Untangling taxonomy: a DNA barcode reference for Canadian spiders. Molecular Ecology Resources 16:325-341.

Bolzern, A. \& A. Hänggi. 2016. Revision of the Nearctic Eratigena and Tegenaria species (Araneae: Agelenidae). Journal of Arachnology 44:105-141.

Bolzern, A. \& P. Jäger. 2015. Unexpected occurrence of the genus Eratigena in Laos with description of a new species (Araneae: Agelenidae). Zootaxa 3920:431-442.

Bolzern, A., D. Burckhardt \& A. Hänggi. 2013. Phylogeny and taxonomy of European funnel-web spiders of the TegenariaMalthonica complex (Araneae: Agelenidae) based upon morphological and molecular data. Zoological Journal of the Linnean Society 168:723-848.

Bolzern, A., A. Hänggi \& D. Burckhardt. 2010. Aterigena, a new genus of funnel-web spider, shedding some light on the TegenariaMalthonica problem (Araneae: Agelenidae). Journal of Arachnology 38:162-182.

Chamberlin, R.V. 1924. The spider fauna of the shores and islands of the Gulf of California. Proceedings of the California Academy of Sciences 12:561-694.
Chamberlin, R.V. \& W.J. Gertsch. 1929. New spiders from Utah and California. Journal of Entomology and Zoology 21:101-112.

Chamberlin, R.V. \& W. Ivie. 1941. North American Agelenidae of the genera Agelenopsis, Calilena, Ritalena, and Tortolena. Annals of the Entomological Society of America 34:585-628.

Chamberlin, R.V. \& W. Ivie. 1942. Agelenidae of the genera Hololena, Novalena, Rualena, and Melpomene. Annals of the Entomological Society of America 35:203-241.

Crews, S.C. \& M. Hedin. 2006. Studies of morphological and molecular phylogenetic divergence in spiders (Araneae: Homalonychus) from the American southwest, including divergence along the Baja California Peninsula. Molecular Phylogenetics and Evolution 38:470-487.

Croucher, P.J.P., G.S. Oxford \& J.B. Searle. 2004. Mitochondrial differentiation, introgression and phylogeny of species in the Tegenaria atrica group (Araneae: Agelenidae). Biological Journal of the Linnean Society 81:79-89.

Darriba, D., G.L. Taboada, R. Doallo \& D. Posada. 2012 jModelTest 2: More models, new heuristics and parallel computing. Nature Methods 9:772

Folmer, O., M. Black, W. Hoeh, R. Lutz \& R. Vrijenhoek. 1994 DNA primers for amplification of mitochondrial cytochrome $\mathrm{c}$ oxidase subunit I from diverse metazoan invertebrates. Molecular Marine Biology and Biotechnology 3:294-299.

Gering, R.L. 1953. Structure and function of the genitalia in some American agelenid spiders. Smithsonian Miscellaneous Collections 121:1-84.

Griswold, C.E. 2001. A monograph of the living world genera and Afrotropical species of cyatholipid spiders (Araneae, Orbiculariae, Araneoidea, Cyatholipidae). Memoirs of the California Academy of Sciences 26:1-251.

Guindon, S., J.F. Dufayard, V. Lefort, M. Anisimova, W. Hordijk \& O. Gascuel. 2010. New algorithms and methods to estimate maximum-likelihood phylogenies: assessing the performance of PhyML 3.0. Systematic Biology 59:307-321.

Ivanova, N.V., J.R. Dewaard \& P.D.N. Hebert. 2006. An inexpensive, automation-friendly protocol for recovering high-quality DNA. Molecular Ecology Notes 6:998-1002.

Hebert, P.D.N., A. Cywinska, S.L. Ball \& J.R. DeWaard. 2003. Biological identifications through DNA barcodes. Proceedings of Royal Society of London Series B 270:313-321.

Librado, P. \& J. Rozas. 2009. DnaSP v5: A software for comprehensive analysis of DNA polymorphism data. Bioinformatics 25:1451-1452.

Llinas, J. \& M.L. Jiménez. 2004. Arañas de humedales de Baja California, Mexico. Anales del Instituto de Biología, Serie Zoología, Universidad Autónoma de México 75:283-302.

Maya-Morales, J. \& M.L. Jiménez. 2013. Rothilena (Araneae: Agelenidae), a new genus of funnel-web spiders endemic to the Baja California Peninsula, Mexico. Zootaxa 3718:441-466.

Maya-Morales, J. \& M.L. Jiménez. 2016. Taxonomic revision of spider genus Rualena Chamberlin \& Ivie 1942 and description of Hoffmannilena, a new genus from Mexico (Araneae: Agelenidae). Zootaxa 4084:1-49.

Paquin, P. \& M. Hedin. 2004. The power and perils of 'molecular taxonomy': a case study of eyeless and endangered Cicurina (Araneae: Dictynidae) from Texas caves. Molecular Ecology 13:3229-3255.

Puillandre, N., A. Lambert, S. Brouillet \& G. Achaz. 2012. ABGD, Automatic Barcode Gap Discovery for primary species delimitation. Molecular Ecology 21:1864-1877.

Ramírez, M.J. 2014. The morphology and phylogeny of dionychan spiders (Araneae: Araneomorphae). Bulletin of the American Museum of Natural History 390:1-374.

Rebman, J.P. \& N.C. Roberts. 2012. Baja California: Plant Field 
Guide. San Diego Natural History Museum, Sunbelt Publications, San Diego, California.

Riddle, B.R., D.J. Hafner, L.F. Alexander \& J.F. Jaeger. 2000. Cryptic vicariance in the historical assembly of a Baja California Peninsular Desert biota. Proceedings of the National Academy of Sciences 97:14438-14443.

Robinson, E.A., G.A. Blagoev, P.D.N. Hebert \& S.J. Adamowicz. 2009. Prospects for using DNA barcoding to identify spiders in species-rich genera. ZooKeys 16:27-46.

Ronquist, F., M. Teslenko, P. van der Mark, D.L. Ayres, A. Darling, S. Höhna et al. 2012. MrBayes 3.2: efficient Bayesian phylogenetic inference and model choice across a large model space. Systematic Biology 61:539-542.

Roth, V.D. \& P.L. Brame. 1972. Nearctic genera of the spider family Agelenidae (Arachnida, Araneida). American Museum Novitates 2505:1-52.

Roth, V.D. \& W.L. Brown. 1986. Catalog of Nearctic Agelenidae. Occasional Papers Museum Texas Tech University 99:1-21.

Sissom, W.D. \& B.E. Hendrixon. 2005. Scorpions biodiversity and patterns of endemism in northern Mexico. Pp. 122-137. In Biodiversity, ecosystems, and conservation in northern Mexico.
(J.-L.E. Cantron, G. Ceballos \& R.S. Felger, eds.). Oxford University Press, Oxford.

Stocks, I.C. 2009. Systematics and natural history of Barronopsis (Araneae: Agelenidae), with description of a new species. Zootaxa 2270:1-38.

Tamura, K., G. Stecher, D. Petersen, A. Filipski \& S. Kumar. 2013. MEGA6: Molecular evolutionary genetics analysis. Version 6.0 Molecular Biology and Evolution 30:2725-2729.

Whitman-Zai, J., M. Francis, M. Geick \& P.E. Cushing. 2015. Revision and morphological phylogenetic analysis of the funnel web spider genus Agelenopsis (Araneae: Agelenidae). Journal of Arachnology 43:1-25.

Wiggins, I.L. 1980. Flora of Baja California. Stanford University Press, Stanford, California.

Williams, S.C. 1980. Scorpions of Baja California, Mexico, and adjacent islands. Occasional Papers of the California Academy of Sciences 135:1-127.

World Spider Catalog 2016. World Spider Catalog. Version 17.5. Natural History Museum, Bern. Online at http://wsc.nmbe.ch/

Manuscript received 29 March 2016, revised 11 September 2016. 


\section{$2 \mathrm{BHL}$ Biodiversity Heritage Library}

Maya-Morales, Julieta et al. 2017. "Four new genera of funnel-web spiders (Araneae: Agelenidae) from the Baja California Peninsula in Mexico." The Journal of arachnology 45(1), 30-66. https://doi.org/10.1636/joa-s-16-024.1.

View This Item Online: https://www.biodiversitylibrary.org/item/274714

DOI: https://doi.org/10.1636/joa-s-16-024.1

Permalink: https://www.biodiversitylibrary.org/partpdf/289890

\section{Holding Institution}

Smithsonian Libraries

\section{Sponsored by}

Biodiversity Heritage Library

\section{Copyright \& Reuse}

Copyright Status: In Copyright. Digitized with the permission of the rights holder

Rights Holder: American Arachnological Society

License: https://creativecommons.org/licenses/by-nc-sa/4.0/

Rights: http://www.biodiversitylibrary.org/permissions/

This document was created from content at the Biodiversity Heritage Library, the world's largest open access digital library for biodiversity literature and archives. Visit BHL at https://www.biodiversitylibrary.org. 